
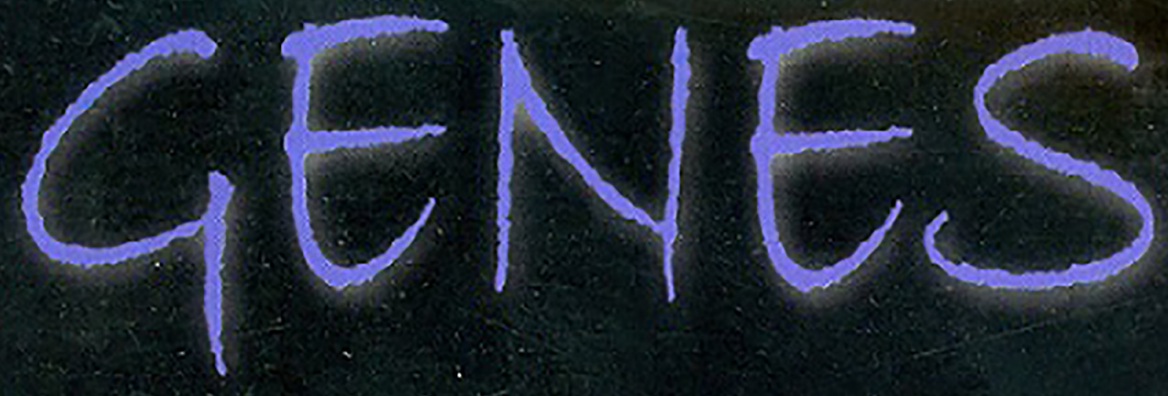

\title{
Fatos e Fantasias
}

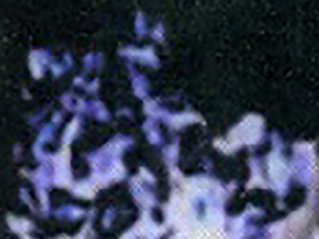
,
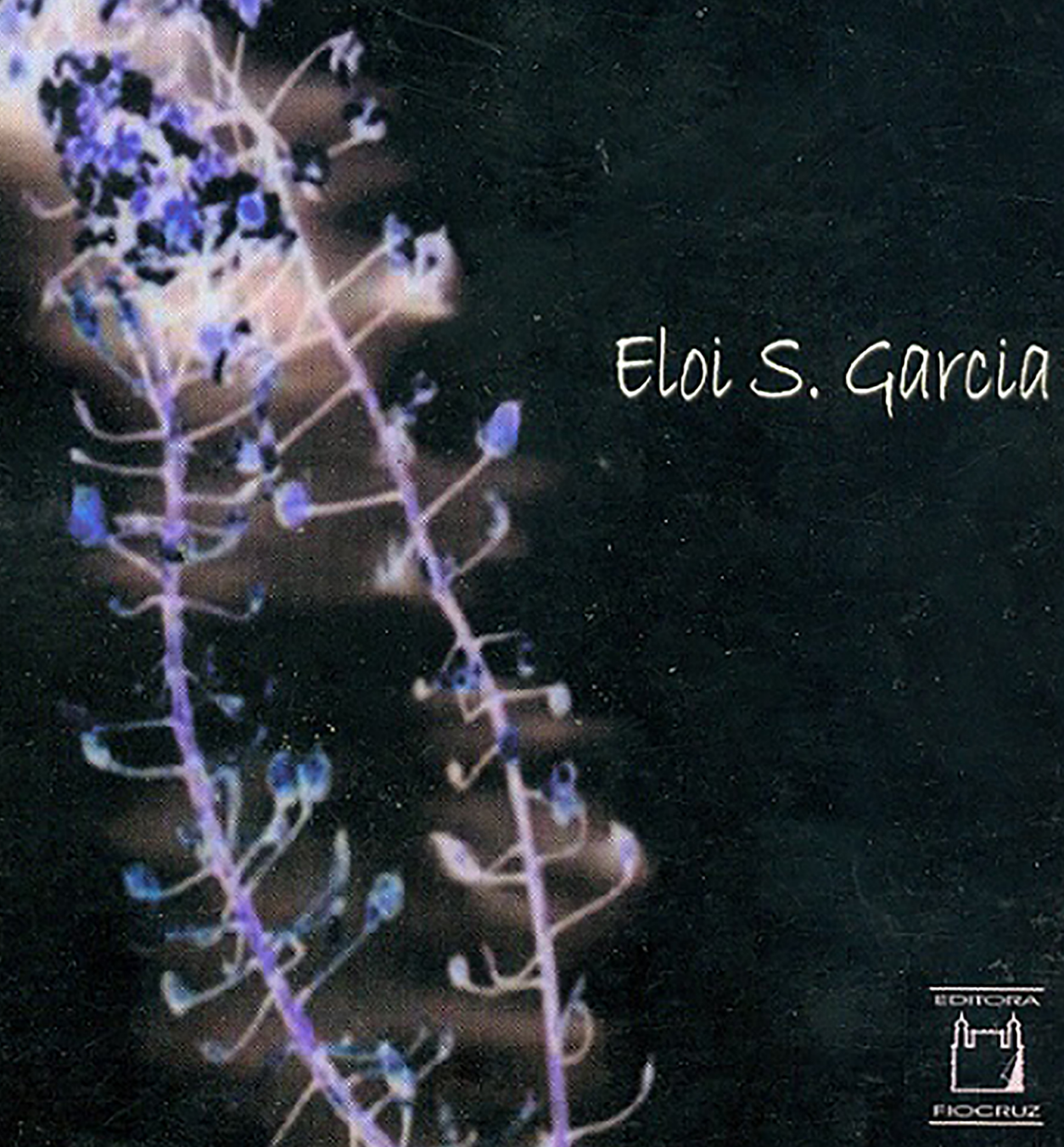

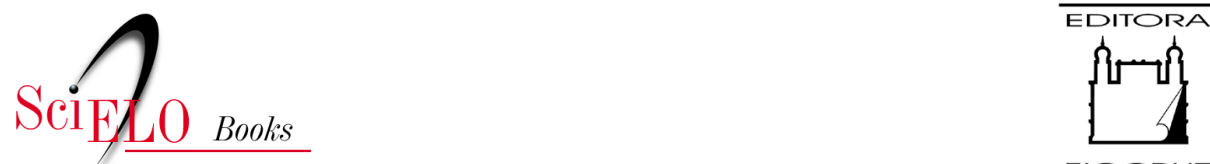

FIOCRUZ

\title{
Genes \\ fatos e fantasias
}

\author{
Eloi S. Garcia
}

GARCIA, E.S. Genes: fatos e fantasias [online]. Rio de Janeiro: Editora FIOCRUZ, 2006, 124 p. ISBN: 978-65-5708-102-0.

https://doi.org/10.7476/9786557081020.

(c) $\underset{\mathrm{EV}}{(1)}$

All the contents of this work, except where otherwise noted, is licensed under a Creative Commons Attribution 4.0 International license.

Todo o conteúdo deste trabalho, exceto quando houver ressalva, é publicado sob a licença Creative Commons Atribição 4.0.

Todo el contenido de esta obra, excepto donde se indique lo contrario, está bajo licencia de la licencia Creative Commons Reconocimento 4.0. 

GENES

Fates e Fantasias 


\section{FUNDAÇÃO OSWALDO CRUZ}

Presidente

Paulo Marchiori Buss

Vice-Presidente de Ensino,

Informação e Comunicaçāo

Maria do Carmo Leal

\section{EDITORA FIOCRUZ}

Diretora

Maria do Carmo Leal

Editor Executivo

João Carlos Canossa Pereira Mendes

Editores Científicos

Nisia Trindade Lima

Ricardo Ventura Santos

Conselho Editorial

Carlos E. A. Coimbra Jr.

Gerson Oliveira Penna

Gilberto Hochman

Ligia Vieira da Silva

Maria Cecilia de Souza Minayo

Maria Elizabeth Lopes Moreira

Pedro Lagerblad de Oliveira

Ricardo Lourenşo de Oliveira 
GENES

Fatos e Fantasias

Elois. carcia

EI 
Copyright@ 2006 do autor

Todos os direitos desta edição reservados à

Fundação Oswaldo Cruz / Editora Fiocruz

ISBN: $85-7541-107-1$

Capa, Projeto Gráfico e Editoração Eletrônica:

Guilberme Asbton

Revisāo e Copidesque:

Janaina de Souza Silva

Catalogação na fonte

Centro de Informação Científica e Tecnológica

Biblioteca da Escola Nacional de Saúde Pública Sergio Arouca

G216g Garcia, Eloi S.

Genes: fatos e fantasias. / Eloi S. Garcia. Rio de Janeiro : Editora

FIOCRUZ, 2006.

$124 \mathrm{p}$.

1. Genômica. 2. Proteômica. 3. Projeto genoma humano. 4. Clonagem humana. 5. Biodiversidade. 6. Biotecnologia. I. Título.

CDD - 20.ed. - 611.01816

2006

EdITORA FIOCRUZ

Av. Brasil, 4036 - $1^{2}$ andar - sala 112 - Manguinhos

21040-361 - Rio de Janeiro - RJ

Tels.: (21) 3882-9039 e 3882-9041

Telefax: (21) 3882-9006

http://www.fiocruz.br/editora

e-mail: editora@fiocruz.br

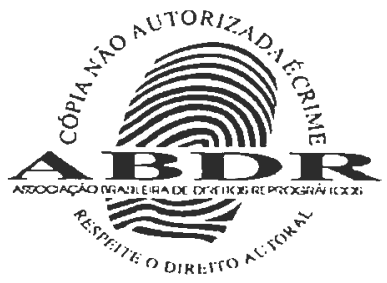


Este livro é dedicado a todos aqueles que participaram de minha carreira científica e dividiram comigo a bancada do laboratório. 



\section{sumario}

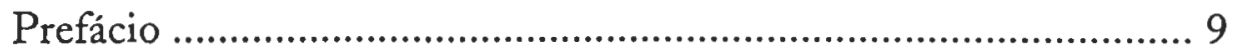

Apresentação .................................................................................. 11

1. Genômica e Proteômica ............................................................ 13

2. Genômica Comparada .............................................................. 51

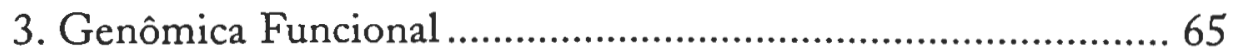

4. Manipulação Genética ............................................................... 79

5. Agricultura e Genes ................................................................ 107

Considerações Finais: genes e responsabilidade ....................... 117

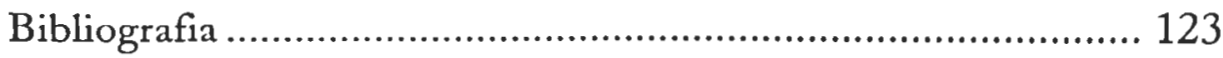





\section{Prefácio}

Há combinações de talentos que são dificilmente encontrados concentrados em uma única pessoa. Eloi S. Garcia é um destes raros indivíduos. Cientista capaz, homem de bancada, pensador sábio e mestre que sabe cativar seus aprendizes, ensinando-os a destrinçar com tranqüilidade as aparentes complexidades das ciências biológicas.

Como se nāo fossem suficientes estas qualidades, Eloi também provou ser administrador competente, que soube conduzir grandes instituiçōes de forma produtiva através dos fortes ventos das intrigas políticas exacerbadas pela escassez de recursos.

O bom uso destes talentos permitiu-lhe imiscuir-se de forma ativa e produtiva nas diversas facetas de uma das maiores revoluçōes de nossos tempos, a revolução dos genes. Pessoas como ele enxergam o mundo sem preconceitos, encarando com coragem os desafios hoje existentes para a biologia molecular, bem como seus aspectos benéficos, críticos e seus riscos para a sociedade.

Em Genes: fatos e fantasias, Eloi S. Garcia discursa de forma sucinta os principais temas centrais desta revolução, procurando despertar o interesse do leitor, afugentando o medo que o desconhecido desperta em todos nós.

Cada capítulo explora de forma sintética, mas com uma linguagem acessivel ao grande público, a importância das novas descobertas e seu impacto não só no mundo acadêmico, mas principalmente na sociedade como um todo. Parabéns ao autor por mais este livro de divulgação científica.

Leopoldo de Méis

Professor Titular de Bioquímica Médica da Universidade Federal do Rio de Janeiro (UFRJ) e Membro da Academia Brasileira de Ciências (ABC). 



\section{Apresentação}

Este é um livro sobre a fronteira entre ciência e tecnologia que focaliza as novas idéias da era pós-genômica. Muitas pessoas acreditam que a ciência genômica está muito distante de seu cotidiano e da vida que levam. Isto não é verdade! O progresso científico invade as nossas vidas, afeta nossas decisōes mais simples, influencia nossas escolhas, nossos hábitos alimentares, os medicamentos de que dispomos. A ciência deve ser vista com mais compreensão pela sociedade.

Para o público, a ciência é imutável, completamente racional, objetiva, metodológica e livre das influências políticas e sociais. Ciência não é somente evidência e método, também é intuição e criatividade. Assim, a revolução gênica oferece novas e extraordinárias possibilidades para a prevenção e tratamento de patologias, bem como para compreender como os organismos interagem entre si e com o ambiente.

A ciência, às vezes, pode tornar-se de difícil entendimento devido ao fato de os cientistas utilizarem freqüentemente uma linguagem técnica, geralmente complicada, e falarem sobre assuntos abstratos para o leigo. Para não dificultar a leitura deste livro, as informaçōes científicas contidas nos capítulos procuram introduzir idéias e hipóteses atuais, apresentadas em linguagem clara, simples e direta, por vezes, contundente, mas de fácil compreensão.

Numa época de discussão e polêmica acerca das aplicaçōes da biologia molecular, a ciência não está imune à fascinação pública obtida com os últimos avanços da genômica e proteômica. Assim, os temas apresentados discutem as maravilhas da máquina celular. Os artigos dão ênfase à genômica estrutural, comparada e funcional, sistemas biológicos, bioinformática, proteômica, dinâmica das proteínas, farmacogenômica, clonagem, transgênese, além de demonstrarem as oportunidades na era da nova biotecnologia. 
Às vezes, é preciso deixar a euforia de lado e analisar com cautela processos que julgamos já ter compreendido completamente. $O$ desenvolvimento da ciência e da tecnologia na era pós-genômica tem controvérsia e cria questōes éticas e morais que também sāo consideradas neste livro.

Sem um debate livre e amplo, até pesquisas importantes podem tornar-se suspeitas. A opinião pública informada e consciente é meio caminho andado para o sucesso e para a aceitaçāo de uma inovação vinculada à ciência e tecnologia. É fundamental que a sociedade participe do debate e compreenda os impactos da ciência para o futuro da humanidade. Esta é mais uma boa oportunidade para analisar mais profundamente a relação entre ciência e sociedade. 


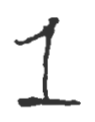

\section{Genômica e Proteômica}

Genômica é o estudo dos genes de um organismo bem como das suas funçōes e interaçōes. A genômica está estimulando a descoberta de novos tratamentos médicos e revelando milhares de novos alvos biológicos (locais de ação de medicamentos) que podem servir para a criação de medicamentos, vacinas e diagnósticos.

Proteômica é um campo emergente que estuda todas as proteínas produzidas pelas células. Este estudo envolve a classificação, caracterização, variaçōes e interações bioquímicas estruturais das proteínas em suas condições normais ou patológicas.

\section{Nem Tudo Está nos Genes}

A pesquisa moderna na genética começou quando Francis Crick com James Watson, após uma caminhada que fizeram até um pub inglês, anunciaram que tinham descoberto 'o segredo da vida'. Desde a descoberta da estrutura do DNA por Watson e Crick, o interesse acadêmico e da indústria biotecnológica pela biologia molecular vem progressivamente aumentando. Nos últimos três anos, esse crescimento se refletiu na mídia, como foi o caso do projeto genoma humano. Após os anos 70, a biologia molecular começou a tomar conta da pesquisa da área biomédica. Tudo tinha de ser compreendido completamente no nível molecular, se possível no nível da genômica. A evolução da enfermidade, sua sintomatologia e consequêencias eram reduzidas ao genoma humano ou do agente infeccioso. Os estudos clínicos, bioquímicos, fisiológicos, imunológicos e patológicos foram perdendo a razão de existir, minimizados pelas investigaçōes dos genes.

As notícias sobre as descobertas da genética molecular, por exemplo, têm levado a sociedade à loucura. Um dia os cientistas encontram genes para asma e para o câncer de pele. No outro dia, são descritos genes de doenças degenerativas nervosas e de síndromes, como a hipertensão, obesidade e depressão. A anemia 
falciforme foi a primeira doença bem definida em termo molecular. Esta doença é causada por uma anomalia na hemoglobina. O problema é devido a uma simples proteína que foi identificada nos anos 40 , seu defeito compreendido nos anos 50 e sua estrutura tridimensional revelada nos anos 60 .

Não resta dúvida de que a genômica, principalmente a comparada e funcional, é fundamental para delinear o mecanismo biológico de uma patologia. A busca é pelo desenvolvimento de um modelo animal que tenha a seqüência genética mais similar à dos seres humanos. $\mathrm{O}$ alvo inicial é realizar modificações genéticas que reflitam na célula ou tecido e o torne sensível, por exemplo, a um hormônio ou a alguma droga que possa reverter a doença no modelo animal utilizado. Se o tratamento funcionar nestes animais, daí entāo, deverá ser testado em seres humanos.

Um dos objetivos almejados pelos pesquisadores é o de criar animais transgênicos que possam desenvolver doenças humanas. Isto facilita a investigaçāo sobre alterações moleculares responsáveis pelas patologias e sobre o efeito de drogas utilizadas na investigação. Distrofias musculares, degeneraçōes nervosas e de órgāos, doenças genéticas que afetam a espécie humana, podem ser investigados em animais de laboratório ou animais domésticos transgênicos. Doenças causadas por mutação genética podem ser graves, normalmente, levando à morte milhares de jovens por deficiências respiratórias, imunológicas ou falhas cardiacas. Várias dessas doenças não têm cura, e os cientistas estão procurando maneiras de inserir nos pacientes os genes responsáveis para bloquear a evolução da doença ou de buscar novos medicamentos para, pelo menos, amenizá-las. Em alguns casos já se consegue inserir genes análogos em camundongos, mas este modelo não reproduz exatamente a doença humana.

Na produção de um animal transgênico vários aspectos científicos necessitam ser analisados com muito cuidado. Por exemplo, estão sendo desenvolvidos animais transgênicos, como a cabra e a vaca, por serem considerados geneticamente próximos aos humanos. Mas a preocupação é de que a modificaçāo genética desses animais possa refletir na qualidade do leite, que é um produto importante em termos nutricionais e de geração de riqueza. É moralmente correto a experimentaçāo em animais como modelos de doenças humanas? É ético usar animais em benefício do ser humano? Não devem ser tolerados experimentos que agridam a ética humana e animal. Se o experimento for um sucesso e, por exemplo, o animal produzir em seu leite uma proteina que beneficie o ser humano com esclerose múltipla, é moralmente correto transformar criaturas vivas em fábricas ou bio-reatores para a indústria farmacêutica humana? 
Este é um ponto complexo porque a maioria dos nossos genes não é exclusivamente do ser humano. Noventa e oito por cento de nossos genes são compartilhados com os chimpanzés, $90 \%$ com os ratos e camundongos, $36 \%$ com os insetos, $23 \%$ com a levedura e $21 \%$ com os vermes. $O$ código genético é essencialmente universal, contendo muitas informações similares em todas as células de diferentes espécies. Ou seja, os genes ultrapassam a barreira das espécies. Por exemplo, a insulina é composta de cerca de 150 aminoácidos, dos quais somente cinco fazem a diferença da insulina humana para a suína. Assim, se a insulina de porco for alterada para insulina humana pela transgênese, o resultado é praticamente o mesmo.

Talvez, para a produção de animais transgênicos, devam ser considerados e reconhecidos os nossos ancestrais mais próximos, que compartilham conosco o maior número de genes. O progresso na compreensão de cada patologia depende do sucesso do trabalho conjunto e multidisciplinar. Para a ciência, as investigaçōes sobre a genômica e da proteômica são da maior importância. No entanto, as promessas exageradas publicadas nos jornais, revistas e programas de rádio e televisão, do que a genômica e o projeto genoma humano podem fazer, não são boas para a ciência biomédica.

Mas, nem tudo está nos genes. Se quisermos que essas áreas sejam benéficas para a população há que se valorizar os bioquímicos, os fisiologistas, os farmacologistas, os imunologistas, os patologistas, os epidemiologistas, os microbiologistas e tantos outros profissionais. Entre os anos 40-60 os cientistas brasileiros estavam trabalhando na bioquímica das frações celulares, células intactas, organismos unicelulares, órgãos de animais e até do próprio homem. Talvez esse período tenha sido considerado 'os anos de ouro' na utilizaçāo do conhecimento gerado pela pesquisa básica e sua aplicação na melhoria da saúde da população.

Não resta dúvida de que a medicina dos anos 60-70 era infinitamente melhor do que a realizada nos anos 30 . Neste periodo as soluções dos problemas vinham de várias maneiras. Por exemplo, os sanitaristas que trabalhavam nos níveis social, cultural, educacional e econômico ficaram responsáveis pelo controle da doença de Chagas. A transmissão da enfermidade pelo vetor em nosso país foi controlada há mais de 25 anos. Os especialistas em cultura de células e tecidos se juntaram aos médicos e aos epidemiologistas e erradicaram a variola e a poliomielite do Brasil. Várias doenças infecciosas foram controladas pela uniāo dos microbiologistas e bioquímicos aos químicos e médicos. 
As infecções ocorriam na natureza devido à existência de bactérias, vírus, fungos ou parasitas, e dependiam da interação molecular entre o germe e o hospedeiro. Desde que Stanley Prusiner descobriu o prion em 1982, a medicina passou a conviver com uma infecção sem um organismo patogênico. Existe um tipo de doença cujo agente infeccioso é uma proteina, sem participação de organismos infectantes. Esta patologia é fatal e apresenta formas diferentes de manifestação nos seres humanos e animais. As partículas protéicas infecciosas são conhecidas como príons, que são proteínas mal formadas capazes de se desenvolverem, replicarem e passarem para células próximas. Além da manifestação da doença, os príons também ocorrem naturalmente em alguns organismos (como a levedura) e podem ter um importante papel no crescimento e desenvolvimento celular.

A descoberta de que proteínas podem transmitir doenças foi uma surpresa para a comunidade científica. O que leva uma seqüência de aminoácidos que induz os príons a se agregar e replicar e assim se perpetuar por geraçōes de células? As proteínas que formam os príons existem normalmente como componentes celulares normais, mas possuem uma habilidade inata para alterar as estruturas tridimensionais de proteínas próximas, as quais mudam suas funções e se tornam quase indestrutiveis. Os prions se propagam por este mecanismo de induzir proteínas normais a modificar suas estruturas terciárias espaciais e se transformarem nestas fortalezas moleculares.

Durante muitos anos acreditava-se na hipótese que o prion era uma única proteína que poderia gerar diferentes tipos moleculares com variados graus de infectividade. Recentes pesquisas estabeleceram que os príons podiam ser decorrentes de estruturas mal formadas de uma mesma proteína. Esta descoberta pôde esclarecer como os prions causam doenças nos seres humanos e animais. Estes dados foram obtidos com prions de levedura, os quais são similares aos príons de mamíferos que causa patologia fatal, destruindo o cérebro humano doença conhecida, em bovinos, como mal de Creutzfeldt-Jacob, encefalopatia espongiforme, mal da vaca louca, e, em ovinos, como scrapie.

Com base nos dados dessas pesquisas foi levantada a hipótese de que os príons transmitem suas características via interação proteína-proteína, na qual um prion com conformação tridimensional anormal influencia sua contrapartida a assumir o enovelamento irregular. Nos mamíferos, a infecção por prions induz proteínas anormais, que formam massas insolúveis, que se aderem na superfície dos neurônios levando a formaçōes esponjosas. 
Os prions afetam diferentes regiōes do cérebro. A morte das células nervosas infectadas dá ao cérebro a aparência de uma esponja, daí o nome genérico da doença, encefalopatia espongiforme. Em células de levedura a proteína príon insolúvel não é letal; ela altera o metabolismo celular. Tanto os príons de mamíferos como os de leveduras adotam conformaçōes infecciosas similares, caracterizadas pelo alto conteúdo de lâminas beta (43\%), com de alfa-hélices (30\%). Estes agregados, conhecidos como amilóides, estão também associados a várias doenças neuro-degenerativas de origem não infecciosa, incluindo Alzheimer e Parkinson.

A produçāo de tipos diferentes de príons pode levar a conformações que infectam espécies diferentes dos animais originalmente infectados. Vários experimentos realizados demonstraram que cepas diferentes de príons de levedura podem transmitir suas características estruturais específicas simplesmente moldando outras proteínas. Estão sendo desenvolvidas técnicas para produzir tipos específicos de proteínas príons de levedura variando a temperatura na qual as proteínas enoveladas são novamente produzidas em suas conformações infectivas.

Em tubos de ensaios os pesquisadores demonstraram que as conformações produzidas nas proteínas, em diferentes temperaturas, propagaram suas estruturas em tipos distintos de príons, provendo moldes em suas formas para o enovelamento de outras proteínas. Estas proteínas de diferentes conformaçōes, quando introduzidas em células de levedura, induziram a produção de diferentes tipos de príons, que passaram suas propriedades moleculares e biológicas a várias gerações destas células. Este fato comprovou a hipótese de que a doença da vaca louca e outras relacionadas são causadas somente por proteínas príons.

Extraindo as proteínas príons de gerações subseqüentes das células, verificouse que tais proteínas tinham as mesmas propriedades da proteína original que infectou a levedura. A habilidade de produzir, manipular e investigar tipos distintos de prions em levedura permitirá estudos mais detalhados de como as proteínas amilóides se formam e propagam. Essas investigaçōes serāo bastante úteis para dirigir futuras pesquisas sobrẹ as propriedades dos prions que causam a doença nos mamíferos e sobre como estas proteínas se infectam em diferentes espécies animais.

Pequenas quantidades de formas diferentes de proteinas prions obtidas de espécies de diferentes mamíferos, quando colocadas em contato com proteínas normais de uma das espécies, podem formar um novo prion, o qual absorve as 
propriedades do prion da espécie fornecedora. Ou seja, esta nova espécie de prion tem a mesma seqüência inicial de aminoácidos, porém adquire a conformação molecular tridimensional e a especificidade do prion que serviu de molde à proteina.

Assim, este príon pode infectar outras espécies de organismos, o que nāo ocorria com a proteína em sua forma original. O fato descrito levanta novas hipóteses para um problema complexo, que é a passagem de uma proteína anormal por diferentes espécies de mamíferos. Este fenômeno também ocorre nos príons de leveduras.

A aparente habilidade de prions diferentes adotarem novas especificidades, contornando as barreiras naturais entre as espécies, tem implicação nos fatores de risco envolvidos na transmissão das doenças de príons animais para os seres humanos. Agora os pesquisadores possuem uma ferramenta de trabalho para explorar o mecanismo molecular pelo qual a proteína espontaneamente muda sua estrutura tridimensional para causar a doença.

\section{Novas informações}

1) Recentemente, os príons foram purificados sendo retirados contaminantes, como micróbios, vírus, bactérias, ou quaisquer agentes que contenham DNA ou RNA. Estas proteínas purificadas foram inoculadas em cérebros de camundongos que posteriormente apresentaram a doença. Foram também sintetizados fragmentos grandes da molécula protéica normal que poderia gerar o príon. Estes fragmentos foram enovelados anormalmente e inoculados em camundongos. Após um ano, estes animais desenvolveram a doença da 'vaca louca'. Os cérebros desses camundongos inoculados em animais normais causaram o aparecimento da doença em seis meses. Isto demonstrou, pela primeira vez, que um fragmento protéico do príon, sintetizado em tubos no laboratório, era suficiente para transformar, nos animais, as proteínas em prions infecciosos.

Este fato representa o renascimento da biologia do príon, pois agora se tem uma ferramenta capaz de explorar, no laboratório, o mecanismo pelo qual a proteína pode-se enovelar espontaneamente para forma espacial que causa a doença. É uma curiosa ironia que este conhecimento tenha sido divulgado na mesma semana que Francis Crick morreu. Este cientista afirmava desde o início que o código genético era universal para todas as formas de vida e formulou o dogma central da biologia molecular que afirmava que a seqüência normal de 
eventos vem do DNA para RNA e deste para proteínas. O dr. Prusiner postulou que para a produçāo de príon não são necessários DNA e RNA.

2) A revista Science, de 11 de novembro de 2004, publicou um artigo que mostra que a variação genética pode causar resistência ao mal da 'vaca louca', levando a uma diferente forma da doença. Esta anomalia ainda não foi encontrada em seres humanos, mas foi observada em camundongos. É sempre muito complicado aplicar os dados de animais de laboratórios para o ser humano. No entanto, são esperadas outras formas da doença. Como já vimos, a doença é conhecida como encefalopatia esponjiforme bovina (BSE) e destrói o cérebro causando um enorme problema quando contamina o ser humano. Esta patologia causou 146 óbitos na Inglaterra e mais de dez mortes em outros países entre 1980 e 1990. A versão humana da doença não é causada pela BSE, mas é causada também por prion e conhecida como variante Creutzfeldt-Jakob (vCJD).

O trabalho da Science mostra, após uma década de investigação, que a injeção de cérebros de camundongos como príons vCJD, conhecidos por alterar as proteínas produzidas pelos genes MM, leva à aparência de esponja do cérebro. No entanto, cérebros deletados dos genes MM também apareciam como esponjas, uma nova forma da doença que agride o cérebro, mas com depósitos de material diferente na extensão e localização se comparados às formas conhecidas da doença vCJD. A proteína envolvida na doença é conhecida como $\operatorname{PrP}, \mathrm{e}$, dependendo de uma diferença genética, pode existir em duas formas no homem: M129 (considerando o aminoácido a metionina) e V129 (a valina). Os camundongos contaminados com a forma humana da doença ( $P r P$ M129) podem apresentar sintomas da vCJD, enquanto que, quando apresentam a forma V129, são resistentes. Quando estes camundongos resistentes tornam-se infectados, aparece uma forma nova da patologia. O fato mais chamativo do artigo é a possibilidade de aparecer uma nova doença causada por príon não associada ao BSE e vCJD.

\section{A 'Finalização' do Projeto Genoma Humano}

Em fevereiro de 2000, Francis Collins e Craig Venter, os dois líderes do Projeto Genoma Humano (PGH), junto ao então Presidente Bill Clinton na Casa Branca, anunciaram a 'finalização' do primeiro rascunho da sequiência genômica. Clinton declarou: "estávamos aprendendo a linguagem pela qual Deus criou a vida". No início de 2004, vinte anos após ter sido lançada a idéia 
do projeto mais ambicioso da pesquisa biomédica c após a revelação de inúmeros aspectos dos genes responsáveis pela vida humana, o PGH foi dado como finalizado.

Em futuro próximo, pretende-se dar continuidade a este desafio com a investigação de genes para a determinação da raça, etnia, comportamento, personalidade e patologias. Outros enfoques genéticos importantes para a condiçāo humana, incluindo planos para amenizar as dificuldades éticas, sociais e legais que envolvem este assunto bem como aspectos médicos, também serão investigados. A seqüência de nucleotídeos do DNA levou a decifrar a intimidade e os mistérios da vida, causando um profundo impacto social. Aprendemos rapidamente como os seres humanos são geneticamente semelhantes ou diferentes um dos outros.

A idéia de elaborar um PGH surgiu em 1984. Um grupo de cientistas, reunidos em Utah nos EUA, debatia sobre as maneiras de identificar as mutaçōes genéticas induzidas nos sobreviventes às bombas atômicas que explodiram em Hiroshima e Nagasaki, durante a Segunda Guerra Mundial. Em 1987, o Departamento de Energia americano, em seus relatórios, já recomendava ao governo realizar um esforço para determinar a seqüência do genoma humano. Não se sabe como, mas esta idéia foi apoiada por alguns setores mais conservadores da sociedade americana. Em 1990, o congresso americano disponibilizou recursos financeiros para a realização do PGH. Os esforços embutidos nos objetivos do PGH foram comparados aos desafios de elaborar a tabela periódica no século $\mathrm{XIX}$, a qual ordenou sistematicamente os cem átomos conhecidos, de modo que fossem detectadas suas similaridades e diferenças.

O projeto tinha como prazo para encerramento o ano de 2005 e o compromisso de tornar todos os dados públicos. Muitos acreditavam que o PGH não poderia ser realizado no período estipulado para a tarefa. A tecnologia necessária para a realização do projeto ainda era precária, fragmentária e quase indisponível. Os primeiros anos foram dedicados principalmente ao desenvolvimento de metodologia para seqüenciar fragmentos de DNA e avançar na parte da biologia computacional, armazenamento e análise das seqüências (bioinformática).

Os genes são compostos de DNA, que é uma molécula formada de 4 bases: adenina (A), timina ( $T$ ), guanina $(G)$ e citosina $(C)$. Cada molécula de DNA consiste em duas fitas, com a base nitrogenada ligada por pontes de hidrogênio a uma base da outra fita, processo conhecido como pareamento das bases (A- 
T e G-C), levando à famosa estrutura da dupla hélice. A tecnologia do seqüenciamento revela as ordens das bases em cada fita que compōe o DNA.

$\mathrm{O}$ PGH envolveu um enorme, estafante, metódico e rotineiro trabalho de laboratório. A determinação da seqüência não poderia ser realizada por um simples grupo de pesquisadores. Assim, a realização da tarefa somente foi possivel com a formação de uma rede de laboratórios, principalmente nos EUA e Europa. Somente nos EUA foram 258 laboratórios, financiados pelo Instituto Nacional de Pesquisa do Genoma Humano (NHGRI), criado em 1989 para administrar o PGH, o qual é parte dos Institutos Nacionais de Saúde (NIH).

Com um custo estimado de USS 2,6 bilhōes, a seqüência do genoma humano forneceu a ordenaçāo de 3,1 bilhōes de letras que compōem o DNA, preenchendo os espaços que ainda faltavam e corrigindo erros observados nos primeiros dados apresentados, em 2000, em cerimônia na Casa Branca.

A seqüiência foi divulgada cinqüenta anos após de James Watson e Francis Crick terem publicado na revista Nature Reviezus Genetics o histórico trabalho da revelaçāo tridimensional da estrutura do DNA. Esta descoberta revelou, pela primeira vez, a conformação do DNA e a base química da hereditariedade. Após a revelaçāo da estrutura do genoma, muitos processos bioquímicos necessitaram ser compreendidos. Por exemplo, como os genes realmente são ativados e inibidos no ato do desenvolvimento e manutenção de um organismo ou do próprio ser humano. Ou seja, como certas regiōes do genoma, que codificam as instruçōes genéticas responsáveis pelo desenvolvimento de um ser vivo, são reguladas.

É difícil desenvolver um programa de computador que identifique os genes ao longo da imensa fita de DNA. Procurar genes no DNA é como tentar localizar uma agulha no palheiro. Genes são como ilhas espalhadas no oceano do genoma. A estimativa final é de que o genoma humano é constituído de cerca de 30 mil genes, bem menos dos 100 mil que se pensava inicialmente. Mas, estes números ainda podem mudar, pois continua a análise em busca de novos genes. A longa fita do DNA é formada de regiōes codificantes (genes), que representam somente $1,5 \%$ do genoma e que controlam a sintese de proteínas no organismo. Mas grande parte do DNA ( $98,5 \%$ do genoma) possui regiões não codificantes que foram conhecidas por vários anos como DNA lixo. Os cientistas estão trabalhando nestes segmentos misteriosos do DNA, que parecem ser essenciais para a sobrevida dos vertebrados, mas cuja função ainda é totalmente desconhecida. 
Tais segmentos são ultraconservados na linha evolutiva e podem ter funçōes nunca imaginadas antes. Em um estudo de genômica comparada, feito $\mathrm{cm}$ uma 'varredura' em duzentas ou mais regiōes do DNA lixo do ser humano, do camundongo e do rato, foram encontrados mais de oitocentas bases que eram absolutamente iguais entre as três espécies. Embora 111 destes elementos ultraconservados coincidam com regiōes de genes conhecidos por codificar proteínas, 256 demonstraram não ter coincidência com genes, e em 114 regiōes os resultados não foram conclusivos. Nas 111 regiōes que coincidiam com os genes, somente uma pequena porção estava em regiōes realmente codificantes. Várias estavam em regiões não que nāo eram traduzidas pelos RNA mensageiros, ou em regiōes que eram deletadas antes da mensagem ser traduzida para proteína. Isto é realmente uma surpresa. A seqüência dos genes que compōem os genomas do camundongo, do rato e do homem, por exemplo, apresenta somente $85 \%$ de similaridade.

Assim, concluímos que cerca de $1 / 4$ das seqüências do DNA lixo coincide com regióes do genoma que sāo codificantes e podem ser convertidas em RNAm - a molécula intermediária que codifica as proteínas. Estas seqüências, geralmente envolvendo um gene que produz diferentes protcínas, podem ser retiradas, ou não, da molécula de RNAs de diferentes formas, dependendo de como sāo transcritas. Um outro grupo de segmentos de DNA lixo nāo está associado com genes, e sim, possivelmente, com a regulação genética, a transcrição do DNA para RNA, ou a ligaçāo com proteínas regulatórias do DNA. Foi descoberto no DNA lixo de leveduras uma nova classe de genes - o gene chamado SRG1 que sintetiza uma molécula de RN $\Lambda$, o qual reprime ou inativa a funçāo do gene adjacente.

Aparentemente, as regiōes conservadas, que não coincidem com os genes, estão envolvidas na regulação da transcrição. Entretanto, se isto é verdade, como elas funcionariam ainda é um mistério. $O$ que os cientistas acham mais interessante sobre estes dados é que eles levantam mais questões do que respostas. Por exemplo, vários elementos conservados nāo vinculados a genes tendem a se agrupar em certos locais dos cromossomos. Estes grupos estão freqüentemente próximos a genes e são conhecidos por terem papéis na regulação de atividade de genes envolvidos no desenvolvimento embrionário. $O$ fato de as regiōes conservadas no processo evolutivo estarem agrupadas espacialmente ao redor dos genes importantes para o desenvolvimento sugere que elas têm algum papel na regulação dos processos do desenvolvimento e diferenciação, ainda que no segmento linear estas regiōes estejam distantes do gene. 
Estas regiōes similares coincidem também com as das aves e cães. Entretanto, estes segmentos foram menos conservados no genoma de um peixe chamado fugu. Quando se estende a comparação para genomas mais antigos, como da Drosophila e do verme, quase não se encontram estes elementos conservados. A conclusão mais interessante é que as regiōes ultraconservadas identificadas parecem representar inovações evolucionárias que podem ter ocorrido em alguma época durante a evolução dos vertebrados. Talvez, as espécies de cordato tenham evoluído quando nossos ancestrais ainda estavam no oceano, quando os animais iniciaram a colonização do solo. Após este período, os segmentos gênicos foram mantidos congelados nas aves e nos mamíferos.

Uma nova visão sugere que muito dos códigos contidos no DNA são para síntese de RNAs especiais, não codificantes de proteinas, os quais agem com moléculas reguladoras. Estes RNAs podem agir ligando-se a RNAs mensageiros, tornando-os inativos, e também podem funcionar como reguladores da atividade gênica. Assim, a grande parte da estrutura do DNA é para produzir estes RNAs regulatórios não codificantes de proteínas. Olhando para além dos genomas, estes segmentos do DNA lixo do homem, camundongo e rato possuem $97 \%$ de similaridades e $95 \%$ deles são semelhantes aos das aves. O fato de estes segmentos terem sofrido poucas mudanças nos 400 milhões de anos de evolução em que o peixe e o ser humano dividiram um ancestral comum mostra que estes segmentos do DNA lixo são essenciais para os descendentes destes organismos.

Recentemente, os pesquisadores descobriram que é ativada a expressão de genes em óvulos fertilizados de mamíferos nos estágios iniciais de desenvolvimento embrionário $\mathrm{cm}$ parte por regiōes do DNA que podem ter origem de retrovírus. Estas regiões, encontradas em DNA humano, do camundongo e de outros mamíferos em centenas de cópias, são chamadas de retrotransposons devido ao fato de terem a habilidade de se propagarem e inserirem em posições diferentes do genoma. Estas regiōes parecem não serem apenas DNA lixo, elas podem ser sítios repositórios para iniciar a expressão gênica. Assim, regiões do DNA antes consideradas nāo funcionais podem ter um papel importante na regulaçāo da expressão e na promoção da diversidade genética. Tais elementos podem sincronicamente iniciar a expressão de genes múltiplos relacionados ao desenvolvimento do embrião e, devido à inserção randômica de tais regiōes, podem introduzir variaçōes potenciais em genes modificando suas funçōes. A expressão de retrotransposons pode contribuir para a reprogramação do genoma embrionário dos mamíferos, um pré-requisito para o desenvolvimento normal. 
Os erros no genoma podem ser encontrados pelo computador, e talvez corrigidos por ele. Se isto for verdade, o conceito de um gene como uma simples seqüência de segmento do DNA está se evaporando. No início do PGH, a identificaçāo de um simples par de bases, ou letra do código genético, custava cerca de US\$10, e um técnico altamente especializado poderia seqüenciar 10 mil pares de bases por dia. Hoje, com o avanço tecnológico na área, o custo da identificação de um par de bases é de 5 cents, e os equipamentos robóticos chegam a seqüenciar 10 mil pares de bases por segundo. Em 2000, a freqüuencia de erros encontrada na seqüência do DNA era de 1 para cada 10 mil bases, agora é de 1 para 100 mil, e a distância ao longo da seqüência onde poderia ter uma falha era de 82 mil bases; agora é de 27 milhões de bases.

No entanto, embora o PGH esteja formalmente 'finalizado', a seqüência do genoma ainda não está completada. Aproximadamente $1 \%$ do genoma não pode ainda ser seqüenciado pelas metodologias existentes. Deverão ser desenvolvidas novas tecnologias para completar esta tarefa. O atual desafio está sendo a compreensão da biologia molecular básica através da interpretação da vasta informação contida na molécula de DNA. Um grupo de 152 pesquisadores está conseguindo novos detalhes e desenvolvendo um catálogo mais compreensivo dos genes humanos. Para isto, está sendo caracterizado o genoma nāo somente pela sua seqüência, mas também pela sua função e diversidade. $\mathrm{O}$ genoma humano possui aproximadamente 30.000 genes em um organismo que deve produzir mais de $200 \mathrm{mil}$ proteínas diferentes. Isto sugere que existe um mecanismo complexo e interdependente de regulação genética, demonstrando a complexidade da rede genômica e proteômica que diferencia os seres humanos entre si e dos organismos inferiores.

Especialistas em análise do genoma humano, utilizando-se de uma combinação de algoritmos computacionais, processaram 41.118 DNA complementares (cDNAs). Desde que os éxons (regiōes do DNA) foram separados e os introns removidos, estes cDNAs correspondem às versões funcionais destes genes. A comparação destas seqüências do cDNAs com as do genoma levou a validar 21.037 genes funcionais e identificar 5.155 candidatos novos a genes.

O conceito de gene, entretanto, é ainda nebuloso. Uma única seqüência pode ser usada de maneira diferente para sintetizar RNAs e proteínas. Se um gene pode ser expresso em maneira e locais diversos e em tempos variados, não é possível dizer que ele é um único gene. Este é um problema novo a ser 
resolvido. A análise de gene por todos estes métodos tem mostrado seqüências complexas. Por exemplo, parece que as seqüências genéticas tendem ser mais longas no início e no final dos genes que nas regiōes do meio. Ainda nāo há uma explicaçāo para isto. Fragmentos de DNA, às vezes compreendendo milhares de nucleotídeos, estão presentes ou ausentes em genomas de pessoas saudáveis.

As informações do PGH indicaram que o DNA era $99,9 \%$ idêntico entre os indivíduos, apresentando somente $0,1 \%$ de variação, geralmente distribuída por todos os cromossomos. Novos dados, entretanto, revelam que, em 255 regiões do genoma (mais de $0,1 \%$ ), grandes fragmentos do DNA estāo presentes em cópias diferentes entre os indivíduos. Estes estudos mostraram que, por exemplo, algumas pessoas têm 10 cópias do gene da amilase e outras podem apresentar mais de 24 cópias.

A genômica tem tido um profundo impacto nos estudos dos microorganismos e das doenças. Quando os biologistas discutem sobre a revoluçāo genética, prometem o desenvolvimento de novos medicamentos para patologias incuráveis, novos revolucionários tratamentos e uma mudança expressiva nos cuidados médicos. É difícil imaginar o que seria da ciência na ausência da genômica. Desde que o primeiro genoma de uma bactéria patogênica foi divulgado em 1995, mais de 100 bactérias patogênicas e mais de mil vírus foram seqüenciados.

Por todo o planeta há sinais de impaciência e desilusão sobre o que o genoma pode oferecer. Parece que houve um exagero por parte dos líderes do projeto criando uma percepção pública de que o DNA seria a resposta para todos os mistérios biológicos. Por outro lado, especulações financeiras lançaram a idéia de que este conhecimento teria aplicações imediatas. Ledo engano, todos envolvidos no PGH sabiam que não seria assim, ou seja, conheciam o script, mas nāo entendiam a linguagem.

Vários cientistas argumentam que, após quatro anos da revelação do genoma humano, ainda não houve um progresso real no tratamento dos principais males que afetam a humanidade: pobreza, Aids, malária e outras doenças infecciosas. Outros acreditam que houve um gasto de bilhões de dólares no desenvolvimento do PGH, em detrimento de uma pesquisa mais holística. Por exemplo, se gasta milhões de dólares na pesquisa do genoma do plasmódio (protozoário causador da malária) e do mosquito transmissor desta doença, quando não há recursos financeiros na África para utilizar um método simples de prevenir a transmissāo da malária. É difícil rejeitar completamente estes argumentos. 
Apesar do dilema levantado pelas novas descobertas genômicas, ainda é muito cedo para uma reação contrária ao estudo de genomas. Vivemos um período maravilhoso da ciência de nossa época, da descoberta da estrutura de DNA à decodificação genoma humano. Afinal de contas, o DNA contém o nosso passado, pode definir o nosso presente e ser o início de nosso futuro.

$$
\text { Genoma humano - um projeto concluído? }
$$

A revista Nature Reviews Genetics publicou a seqüência 'final' do genoma humano no dia 21 de outubro de 2004. Algumas pessoas ficaram confusas com esta notícia. Antes já tínhamos visto por duas vezes esta divulgação. A primeira em uma cerimônia na Casa Branca em fevereiro de 2000, quando o primeiro rascunho do DNA humano foi completado, e a segunda em abril de 2003, quando o Consórcio anunciou a 'finalização' do PGH.

A surpresa neste artigo foi a redução do número de genes humanos contidos nos cromossomos: de 35 mil genes para somente 20 a 23 mil genes. A seqüencia apresentada representa $99 \%$ da região eucromática (que contém genes) e foi seqüenciada com uma eficiência de $99,999 \%$, o que significa a possibilidade de um erro em cem mil pares de base - 10 vezes mais acurada de que no objetivo original. Desta maneira foi confirmada a existência de 19.599 genes e 2.188 segmentos de DNA 'prováveis' de codificarem proteínas. A média de bases do DNA seqüenciada ininterruptamente equivale a 38,5 milhões de pares de base, isto é, aproximadamente 475 vezes mais longa do que os 81.500 pares descritos anteriormente.

Além da redução do número de genes, os pesquisadores reportaram que a melhor qualidade da seqüência do genoma humano, comparada com os primeiros dados divulgados, permitiu observar uma imagem mais realista de certas regiões como, por exemplo, a duplicação de segmentos do DNA e do surgimento e desaparecimento de certas atividades gênicas. Os segmentos duplicados são extensos, quase cópias idênticas do DNA, apresentando pelo menos duas localizações no genoma. Esta alta proporção de segmentos duplicados demonstra que nosso material genético, nos últimos 40 milhões de anos, sofreu inovações funcionais e estruturais, contribuindo para a separação do ser humano dos outros ancestrais primatas.

A alta qualidade da seqüência do genoma humano revelada no artigo permitiu aos cientistas detectarem mais de mil novos genes que apareceram após nossa divergência dos roedores, processo que ocorreu há cerca de 75 milhōes de 
anos. Muitos desses genes apresentaram duplicaçōes recentes na história do homem e estão envolvidos com a imunidade, o olfato e a reprodução.

Foram também identificados e caracterizados 33 genes - conhecidos como pseudogenes -, que sofreram uma ou mais mutaçōes, conduzindo a perdas funcionais. Por exemplo, dez desses pseudogenes têm função de codificar proteínas envolvidas no olfato. Isto pode explicar por que os seres humanos têm um número menor de receptores olfativos e, conseqüentemente, apresentam a recepção do cheiro menor do que os roedores. Estes estudos deram o prêmio Nobel de fisiologia e medicina a Richard Axel e Linda Buck, em 2004.

Os pesquisadores também alinharam e compararam os 33 pseudogenes com o rascunho do genoma do chimpanzé para investigar se estas seqüências eram ainda funcionais antes de o Homo sapiens divergir dos macacos há cinco milhōes de anos. Esta análise revelou que 27 dos pseudogenes não eram funcionais no homem e no chimpanzé. Entretanto, cinco genes não ativos nos seres humanos eram ativos no primata, o que explica a vantagem olfativa do chipanzé em relaçāo ao homem.

Quando se fala que a seqüência do DNA humano está 'finalizada' não significa que se tem a seqüência perfeita do genoma. Em 2000, por ocasião do primeiro anúncio do rascunho do genoma humano, havia 150 mil regiōes desconhecidas. Agora somente permanecem 341 brechas no DNA que necessitam novas tecnologias para serem desvendadas. Assim, esta publicaçāo da Nature Reviews Genetics ainda não é o final da história. Há algumas regiōes do genoma humano que não podem ser elucidadas pelos métodos utilizados até agora. Nos próximos cinco anos poderão aparecer novas histórias sobre a 'finalização' do DNA humano.

\section{- Retorno das Zoonoses}

O mundo está ficando pequeno para seus habitantes. Em busca de novas áreas para plantio ou exploração, o ser humano devasta florestas, drena pântanos, constrói estradas e represas, invade regiōes e florestas virgens à procura de riquezas. As viagens internacionais estão ficando cada vez mais freqüentes e mais ousadas. Qualquer região deste planeta, antes inexplorada e inexplorável, pode ser atingida por uma pessoa em 24 horas. A locomoção de um indivíduo permite que ele tenha contato, por exemplo, com um vírus na África ou no Brasil e, no outro dia, esta pessoa poderá estar caminhando nas ruas de Nova Iorque, Londres, Paris ou Rio de Janeiro. 
Os cientistas estão extremamente preocupados. As mudanças causadas no planeta, principalmente aquelas relacionadas ao desenvolvimento cconômico, estāo alterando o ecossistema, aumentando a possibilidade de novos agentes patogênicos se propagarem e causarem riscos à saúde humana e animal. Ou seja, as mudanças ecológicas estão influenciando na epidemiologia das zoonoses, podendo ser de origem natural ou antropogênica, quando considerada a economia. Estas alteraçōes incluem, mas não estão limitadas, a expansão da população humana, o reflorestamento e outras trocas no habitat, poluiçāo ou mudanças climáticas. Um exemplo mais global do que isto representa é o caso de vírus da Aids. Inicialmente, devido ao desenvolvimento da rede viária no interior do continente, o vírus infectou caçadores que tiveram acesso às florestas tropicais da África. A doença se propagou pelo contato humano e tornou-se uma tragédia global devido à relativa facilidade das pessoas viajarem pelo planeta.

Novas doenças aparecem ou emergem, como a gripe espanhola, que se espalhou pelo planeta em 1919, matando de 30 a 50 milhōes de pessoas. Esta doença tirou mais vidas do que a primeira guerra mundial. A gripe asiática, de 1957 , levou quase 100.000 vidas, e a de Hong Kong matou aproximadamente 50.000 indivíduos, em 1968.

Uma nova epidemia é esperada. Não se sabe se ela virá de forma natural ou mesmo por um ataque terrorista. Uma nova ameaça para a humanidade poderá ocorrer por um novo micróbio ou por uma mutação de um microorganismo já conhecido. Não resta dúvida que os agentes patogênicos continuam evoluindo. Novos micróbios têm sido descobertos e merecem uma atençāo permanente das autoridades responsáveis pela saúde pública, pois poderāo causar epidemias.

Dos novos microorganismos identificados podemos citar o hantavírus, responsável pela síndrome pulmonar, o ébola, os vírus Lasso e Marburg que são agentes causadores da febre hemorrágica, o vírus Nipa da encefalite, o microorganismo causador da doença dos legionários e a cepa de Escherichia coli, responsável por uma diarréia sanguinolenta e alterações renais. Vários casos já apareceram nos noticiários rotineiros da mídia como prováveis infecções zoonóticas ainda sem explicações científicas convincentes.

Embora várias doenças sejam transmitidas entre a mesma espécie (espécieespecífica, ou seja, aquelas enfermidades que podem ocorrer em uma única espécie animal), outras tantas podem se propagar entre diferentes espécies. São consideradas zoonoses, as doenças de animais que passam ao ser humano, ou seja, a passagem de agentes infecciosos entre os animais, domésticos ou selvagens, e o homem. Algumas zoonoses são bem conhecidas, como a praga, a doença de 
Lime, a raiva, a influenza, várias verminoses e doenças parasitárias de cães, gatos e outros. Em 2001 foram catalogadas 1.415 agentes patogênicos para o ser humano, $62 \%$ destes tinham origem nas zoonoses.

Especialistas acreditam que há risco de novas viroses animais contaminarem o ser humano. Trinta e cinco doenças zoonóticas já foram descritas nos últimos 25 anos. Dezenas de doenças graves, transmitidas por animais, serão descobertas nos próximos 50 anos. A maioria delas será detectada na América Central e do Sul, África e Ásia.

A passagem de micróbios dos animais para o ser humano é conhecida desde os tempos remotos. Há milhares de anos, quando os primeiros pequenos aglomerados humanos se formaram e os animais começaram a ser domesticados, iniciaram-se as permutas de germes entre os animais e o homem. Há dois mil anos o ser humano começou a viver em grandes cidades e esta situação piorou.

É importante saber mais sobre a interface existente entre o homem e animais e como e por que certos microorganismos ultrapassam as barreiras das diferentes espécies animais e passam ao ser humano. Certas zoonoses causam doenças devastadoras. Um exemplo marcante de zoonose é o próprio vírus HIV, que está causando a pior pandemia desde a peste no século XIV. Originado de macacos selvagens, passou ao ser humano em poucas décadas, causando a Aids. Em contrapartida, acredita-se que o coronavírus responsável pela Síndrome Respiratória Aguda Grave (Sars) contaminou ao homem através de gatos selvagens asiáticos. Recentemente, uma nova gripe asiática, possivelmente, transmitida por aves, causou várias mortes no Vietnã e quase se transformou em uma pandemia.

Doenças como a Sars, HIV e a gripe asiática, provavelmente tornaram-se infecções zoonóticas por uma razão básica do processo evolutivo dos organismos. $\mathrm{Na}$ realidade, todos que pensam ecologicamente não ficaram surpresos com o aparecimento dessas doenças. Estas viroses estão tentando se evoluir. Por exemplo, os cientistas acreditam que as pandemias mortais de influenza tiveram início na Ásia e foram transmitidas por animais. Possivelmente a cepa virulenta do vírus se desenvolveu onde porcos e aves são criados juntos, em locais próximos a fazendas. Os suínos foram infectados pelo vírus de pato, e este vírus, ao recontaminar os porcos, infectou os seres humanos, criando epidemias desastrosas para o planeta.

Um dos grandes problemas das epidemias humanas é que um vírus que circula entre animais, sofrendo uma mutação, pode tornar-se um agente agressivo 
às pessoas. Como isto pode ocorrer? É um risco sério? Por exemplo, uma cepa de influenza A tem circulado pelo mundo há dezenas de anos. Este microorganismo normalmente se propaga somente entre as aves, causando, por vezes, uma patologia menos grave e, em outras vezes, uma doença grave, levando a uma grande incidência de mortalidade entre estes animais.

O vírus é essencialmente um parasita que penetra numa célula e utiliza a sua maquinaria metabólica e reprodutiva para se dividir (replicar). Para sobreviver com sucesso, este organismo deve se adaptar à célula infectada. Muitos vírus não sofrem mutaçōes facilmente. $\mathrm{O}$ vírus $\mathrm{H} 5 \mathrm{~N} 1$ da influenza aviária, como o HIV, notoriamente é uma exceção. $\mathrm{O}$ microorganismo da influenza possui um alto índice de mutaçāo, o que significa que é muito flexivel e pode se adaptar a novos ambientes. Este vírus pode sofrer mutação de duas maneiras: uma de mudanças mais lentas, com reflexo pequeno na saúde pública, pois o indivíduo contaminado tem tempo para desenvolver resistência produzindo anticorpos. $\mathrm{E}$ a outra, de transformaçōes genéticas rápidas, que podem originar novas epidemias.

A maior transformação genética ocorre quando um tipo de vírus animal permuta genes com um virus relacionado. Desta maneira, o novo vírus pode ganhar características que não tinha antes, tornando-se competente e mais virulento ou contagioso ao homem. Este é o caso do H5N1 que pode fundirse com um virus comum da gripe humana, talvez em alguém que tenha influenza, ou com um vírus de um animal, como o porco, o qual pode estar contaminado pelo vírus da gripe humana e aviária. Assim, um novo vírus letal e contagioso pode surgir. Dados recentes demonstraram que este vírus coletado em 2002 é muito mais infeccioso para frangos e camundongos do que o vírus isolado em 1997. Isto pode indicar pequenas mudanças genéticas no H5N1. No entanto, o virus $\mathrm{H} 5 \mathrm{~N} 1$ possui quatro obstáculos genéticos e ambientais que dificultam a sua contaminação na população humana. $O$ primeiro é que a replicação viral em células humanas não é muito eficiente. Ou seja, somente uma pequena concentração do vírus pode ser espalhada pela tosse ou espirro. $O$ segundo obstáculo é que o vírus aviário é incapaz de infectar eficientemente células humanas. Aparentemente, o receptor celular de certos tipos de células humanas não é muito adequado ao vírus. A terceira dificuldade é que o vírus aviário é encontrado no tubo digestivo das aves, onde a temperatura é em torno de $37^{\circ} \mathrm{C}$. No trato respiratório humano a temperatura é de cerca de $33-34{ }^{\circ} \mathrm{C}$. Esta diferença de temperatura pode prejudicar a replicação virótica. O último 
obstáculo é que as viroses aviárias estāo bem adaptadas e escapam do sistema imune das aves. Entretanto, nāo conseguem fugir do sistema de defesa humano.

Aparentemente, o vírus $\mathrm{H} 7 \mathrm{~N} 3$, que ataca maciçamente os frangos, não entrou ainda em contato com nenhum material genético humano. Esse vírus não é normalmente letal, mas alguma coisa acontece com ele, que passa a ser altamente patogênico. O H7N3 é diferente da cepa $\mathrm{H} 5$ que matou várias pessoas bem como milhares de frangos na Ásia. O H e $\mathrm{N}$ representam diferentes proteínas. Existem 15 variedades de $\mathrm{H}$ e 9 de $\mathrm{N}$. As proteínas se combinam de diferentes modos para fazer as viroses específicas, algumas mais mortais que outras.

Recentemente foram revelados detalhes de como o vírus da gripe espanhola, originada de uma gripe aviária, se transformou na epidemia mais destrutiva da história. Devido ao fato de o vírus manter as caracteristicas básicas de seu precursor aviário, ele pode escapar do sistema imune, causando uma alta disseminação entre indivíduos e uma mortalidade extraordinária. Baseando-se em amostras isoladas de vítimas preservadas e enterradas em regiões cobertas permanentemente de gelo no Alaska, os cientistas reconstruíram partes do genoma do vírus extinto. Regiōes do genoma reconstruído foram usadas para produçāo de proteínas do vírus, principalmente uma glicoproteína (hemaglutinina) de membrana conhecida com HA.

Esta molécula tem um papel crucial nos primeiros estágios da infecçāo virótica, em que o vírus se adere nas células humanas e sofre o primeiro ataque pelo sistema imune. O HA do vírus da gripe de 1918 é similar aos vírus de origem aviária. Isto explica a razão desta pandemia ter sido tão letal. A proteína HA pode ser reconstruída em forma tridimensional após sua cristalização e após a determinação da estrutura ter sido estudada em raios-X. Esta molécula foi comparada com a do virus da gripe aviária atual, cepa A (H5N1) e foi demonstrado que elas não são semelhantes e se aderem em células humanas de modos diferentes.

Baseando-se nos dados da epidemia de 1997 em Hong Kong, estas variações explicaram porque o $\mathrm{H} 5 \mathrm{~N} 1$ se espalha pelos seres humanos de modo limitado, em contraste com o vírus de 1918 que tem a habilidade de ser propagado rapidamente. $\mathrm{O}$ vírus $\mathrm{H} 5 \mathrm{~N} 1$ necessitaria de mais mutaçōes para transformar em infectante e contaminar de pessoa a pessoa. Em parte, a grande mortalidade de 1918 foi devida a complicaçōes das infecções secundárias causada por bactérias. Hoje, estas seriam tratadas com antibióticos, de modo que uma epidemia similar àquela seria mais difícil. 
Os pesquisadores acreditam que a evolução dos microorganismos seja a razão de doenças animais passarem aos seres humanos, sendo este processo de ocorrência mais freqüente no futuro. Recentes trabalhos científicos têm demonstrado que as migraçōes de aves, de significado nostálgico às pessoas, pode ser a causa principal da transmissão de virus. Não temos a capacidade de evitar as catástrofes naturais nem as epidemias. Quanto mais mudar a ecologia humana, mais estaremos criando oportunidades para os micróbios e doenças evoluírem e se espalharem pelo planeta. A vigilância sanitária humana e animal deve estar sempre em estado de alerta.

Pela sua natureza, a saúde pública é multidisciplinar, devido à utilização de vários determinantes sociais e econômicos, bem como por ter um enorme espectro de ações de promoção e prevenção da saúde. Assim, causou-nos surpresa a mídia ficar interessada na Sars somente dois anos após começar a surgir conseqüências da epidemia que ocorreu de 2002 a 2003. Em 2003, ocorreram 8.098 casos de Sars, em 29, países causando 774 mortes. Os sistemas de saúde desses países, que deviam estar preparados para enfrentar doenças emergentes e reemergentes, cometeram equívocos primários ao enfrentarem a epidemia. Por exemplo, através do contato com pacientes infectados com Sars, as autoridades de Toronto identificaram 23.103 pessoas que ficaram em quarentena, ou seja, cerca de $1 \%$ da população da cidade. Em Taiwan 211.045 , indivíduos suspeitos de terem contato com pessoas doentes foram isolados entre 10-14 dias. Felizmente, somente 133 destas pessoas foram contaminadas. Situaçōes semelhantes foram observadas em outros países onde a Sars ocorreu. Esta foi a principal lição desta epidemia. Os países devem organizar seus sistemas de saúde para enfrentar epidemias imprevistas ou novas que, de alguma maneira, possam colocar a população em risco.

\section{Sobre a Gripe Aviaria}

Em novembro de 2004, a Organização Mundial da Saúde (OMS) divulgou que, após quase um ano tentando controlar, na Ásia, a gripe aviária, esta é candidata a causar, nos próximos anos, uma pandemia, com possibilidade de provocar cerca de três milhões de casos fatais. $O$ vírus responsável pela doença não somente é resistente, mas também extremamente versátil. $O$ vírus da gripe das aves, H5N1, que causou mais de 30 óbitos humanos na Tailândia e Vietnã além de milhares de mortes de frangos em toda a Ásia, em 2004, é certamente o agente patogênico mais provável para causar a próxima pandemia. Historicamente, as pandemias de influenza aparecem a cada 20 a 30 anos, 
quando ocorrem mudanças no vírus, e a população tem pouca ou nenhuma imunidade para este agente com novo perfil genético.

A OMS acredita que o vírus aviário possa combinar-se ao vírus da gripe humana, criando uma nova forma que pode se espalhar rapidamente pelo planeta, estimando cerca de dois a sete milhões de mortes e bilhōes de pessoas contaminadas.

A vacina para proteger os seres humanos deste vírus deverá estar sendo produzida em 2007, após extensos testes clínicos. Pesquisadores tailandeses isolaram o vírus de cinco casos humanos e enviaram amostras para o Centro de Controle de Doenças nos Estados Unidos. Tais amostras virais estão sendo usadas para desenvolver vacinas contra a doença. A primeira vacina será testada no início de 2005, e os pesquisadores acreditam que em três anos será desenvolvida uma vacina eficiente e segura para proteger a população.

Genômica, Proteômica e saúde

O relatório do Foro Global para Pesquisa em Saúde nos mostra que a maior parte dos recursos financeiros liberados vai para pesquisa de doenças, como a influenza, hepatite, doenças cardiovasculares, diabete, entre outras que afetam problemas globais, principalmente do Primeiro Mundo. Por outro lado, ainda são insuficientes os recursos para pesquisa contra malária, Chagas, Aids, tuberculose, esquistossomose, leishmaniose, filariose, das quais várias predominam ou são problemas exclusivos dos países em desenvolvimento ou menos desenvolvidos. Por isto, estas doenças são consideradas doenças negligenciadas. Entre 1975 e 1999, de aproximadamente 1.200 medicamentos novos existentes no mercado, somente 13 eram para tratar doenças tropicais.

A OMS reuniu-se em Genebra no mês de maio de 2004, em sessāo plenária com todos os 192 países associados. Uma das decisões tomadas pela assembléia foi de como o setor saúde se beneficiará pela enorme revolução ocorrida na genômica e proteômica, células-tronco e transplantes. As investigaçōes foram facilitadas com a divulgação da seqüência do genoma humano bem como de muitos agentes patogênicos (incluindo a malária, cólera, doenças diarréicas, tuberculose, Aids e hanseníase) e de agentes vetores de doenças (como o mosquito Anofeles e o verme Esquistossomo).

O genoma é a seqüência completa do DNA de um organismo. Possuindo um tamanho variável dependendo do organismo considerado, representa a 
unidade de hereditariedade. O menor genoma conhecido é o das bactérias que contém cerca de 600 mil pares de bases, enquanto o genoma humano e de camundongo possuem aproximadamente 2,9 bilhōes. Entre os objetivos do PGH estava a identificação de aproximadamente 30 mil genes e as seqüências dos pares de base, além de tornar os dados acessiveis gratuitamente para pesquisas. O PGH é uma extraordinária fonte de informação sobre o desenvolvimento científico da bioquímica, fisiologia e evoluçāo das espécies existentes no planeta.

O DNA carrega os códigos para síntese das proteínas. Entretanto, até 1960 , ainda era totalmente desconhecido, assim como as informaçōes contidas no DNA eram utilizadas para produzir as proteínas. Sidney Brenner e François Jacob, quando trabalharam na Califórnia, identificaram o RNA mensageiro (RNAm), molécula que transportava as informações contidas no código genético do DNA ao ribossomo, local da síntese de proteínas. O RNAm é produzido no núcleo celular de maneira complementar ao gene contido no DNA e serve como molde para a síntese de proteínas ao ligar-se aos ribossomos, nos quais, através um processo complexo, o código é então traduzido na seqüência de aminoácidos que forma uma proteína particular.

O proteoma representa o conjunto das proteinas que compōe um organismo vivo. Este tema de investigação pretende catalogar e caracterizar as proteínas derivadas do código genético, comparar as variaçōes dos níveis de expressão em diferentes condições, estudar suas interações e identificar suas funçōes na célula. A natureza e a estrutura das proteínas contribuem para a dificuldade da proteômica, fazendo com que ela seja um desafio maior do que da genômica. Por exemplo, as proteinas têm 20 moléculas (aminoácidos) como componentes básicos, enquanto o DNA é composto de somente quatro substâncias (nucleotídeos).

Além disso, a estrutura da proteína pode se modificar. Uma simples proteína pode ser expressa e se estruturar de maneira diferente dependendo do local de síntese em um organismo ou de seu estágio de desenvolvimento. Trabalhar com proteínas é muito mais difícil do que com ácidos nucléicos. As proteínas nāo podem ser amplificadas e são mais raras de serem encontradas. De mais a mais, as proteínas freqüentemente desnaturam durante os experimentos, o que leva a pequenas ou grandes mudanças estruturais em nível terciário e quaternário.

A genômica e a proteômica causaram modificações dramáticas na química dos ácidos nucléicos e das proteínas e no uso de vários sistemas biológicos. A implementação de processos eficientes para culturas de células, regeneração 
de tecidos e fertilização in vitro de animais pode ser realizada devido à disponibilidade de protocolos estabelecidos para utilização das ferramentas moleculares (enzimas de restriçāo, sistemas vetores de DNA, elementos transposomais, promotores, marcadores genéticos, genes clonados etc) pela inserção precisa e rápida de genes úteis em plantas, animais e microorganismos.

Calcula-se que o ser humano, entre proteínas funcionais (enzimas, hormônios, etc) e estruturais (componentes de membranas, organelas, etc), possua de quatro a seis vezes mais proteínas do que o número de genes. A teoria de que um gene codifica uma proteína, como se ensinava na universidade, já saiu dos livros modernos de bioquímica.

O PGH passou quase despercebido pelos laboratórios brasileiros, mas o país acabou investindo bastante em rede genômica de microorganismos e parasitas e, mais recentemente, na rede para investigação da proteômica. A comunidade científica brasileira pôde assim participar ativamente na produção e na interpretação dos dados de genomas e proteomas de diferentes organismos. As informações contidas nas seqüências de DNA, no entanto, não revelam suas funçōes celulares. A transformação dessas seqüências em informações úteis é uma tarefa científica enorme.

A maioria dos medicamentos desenvolvidos tem como alvo a ação funcional e/ou estrutural das proteínas. Estima-se que qualquer proteína codificada por um único gene possa ter inúmeros tipos de variaçōes, que podem ser produzidas de diferentes maneiras: erros resultantes de mutação genética e modificaçōes pós-transcrição e pós-tradução, por exemplo. As vias metabólicas nas quais moléculas de RNAs e proteínas agem e interagem podem elucidar as bases genéticas das doenças humanas e seus tratamentos. As oportunidades e desafios na utilização dessas informações fornecem novos conhecimentos que podem ser convertidos em inovaçōes significantes em termos comerciais.

Cada vez mais aparecem evidências de que a compreensão da genômica e proteômica dos microorganismos e seus vetores facilita a prevenção e o tratamento da doença. Um desses casos foi a divulgação do genoma de três organismos envolvidos em uma enfermidade: o parasita, o mosquito e o ser humano. Este é o caso da malária em que o plasmódio possui cerca de 5.300 genes distribuídos em 24 milhões de pares de base química do DNA; o mosquito, aproximadamente 14.000 genes em 278 milhões de pares de base.

Talvez, a melhor maneira de olhar uma doença é considerarmos os fatores ambientais e genéticos. Enquanto o debate continua, muitas empresas estāo 
investigando a relação entre gene e doença. Numa perspectiva genética, as doenças são causadas quando um gene que devia estar inativo torna-se ativo, ou vice-versa. De qualquer maneira, não resta dúvida de que vários aspectos da saúde ou da doença humana são definidos pelo DNA. Conhecendo a seqüência genética do hospedeiro e do microorganismo causador da patologia, será possível estudar os vários genes envolvidos, as proteínas codificadas por estes genes e como estas moléculas atuam numa patologia. Este enfoque explicará os mecanismos das doenças, de como os microorganismos patogênicos driblam o sistema imune e afetam as funçōes básicas de nosso organismo. Tais informações poderão gerar diagnósticos mais sensiveis e específicos, medicamentos com menores reações colaterais e novas vacinas. Os testes genéticos serão usados para diagnosticar, dar informações do prognóstico, evolução ou estimar o risco de uma doença futura em indivíduos saudáveis ou em suas proles. Por exemplo, mutaçōes no gene PIK3CA são encontradas em diversos tipos de câncer. Este gene e outros de sua família fornecem as instruções genéticas para a síntese de enzimas chamadas de lipídeo-quinases, que modificam moléculas de gorduras. Estes dados abrem oportunidades para o desenvolvimento de terapias específicas que podem ser úteis para tratamento de câncer com mutaçāo neste gene.

Um outro exemplo é a esperança de cura para a diabete tipo 1 . Normalmente, esta doença ocorre devido a uma combinação entre o ambiente e fatores genéticos. No entanto, pessoas que não possuem o gene Sumo-4, que regula o sistema imunológico, também possuem diabete tipo 1 por destruiçāo das células produtoras de insulina no pâncreas. Foi demonstrado, por outro lado, que célulastronco humanas ativam certos genes que têm uma funçāo importante no pâncreas. Os genes da insulina e glucagon normalmente ativados nas ilhotas pancreáticas também foram ativados em células-tronco. O próximo passo será recriar nas células-tronco as condições que produzem insulina e glucagon em resposta ao nível de glicose no sangue.

O conhecimento sobre os genes envolvidos em uma doença e a via metabólica ou o local de ação de um medicamento leva à descoberta de centenas de novas possibilidades de alvos para uma droga. Utilizando-se desta estratégia, medicamentos também têm sido testados em vários tipos de câncer, lúpus, hepatite $\mathrm{C}$, deficiência de hormônio do crescimento, úlceras venosas crônicas, imunodeficiências, doenças cardiovasculares e osteoporoses, entre outras.

Além dos exemplos anteriores, pelo uso da genômica e proteômica, podese produzir insulina humana em animais para tratamento da diabete, ativador de plasminogênio para dissolver coágulos sangüíneos, fator VIII utilizado nos 
hemofílicos para formação do coágulo, ou estreptoquinase e uroquinase na dissolução do mesmo, fatores de crescimento. Estas tecnologias também são utilizadas para controle da poluição ambiental pelo tratamento de lixos e poluidores, como o petróleo, DDT, dioxina, $\mathrm{PCBs}$ e outros químicos que envenenam a natureza com microorganismos (bactéria e fungo) engenheirados.

As investigaçōes sistemáticas e compreensivas da genômica e proteômica de diferentes microrganismos, animais e vegetais levarāo a novos enfoques para entender a biologia nos próximos anos. No Brasil já existe uma massa crítica altamente especializada em ciências biológicas e nas tecnologias da informática aplicada à biologia. É preciso estimular a interação de grupos que trabalham em genômica e proteômica com os que estāo criando ferramentas para acelerar o desenvolvimento de novas drogas. No entanto, ainda há vários senōes quanto ao uso da genômica e proteômica na área de saúde. Nos anos recentes, o desenvolvimento da medicina parece depender quase que exclusivamente da genômica médica. A idéia de produzir novos medicamentos utilizando o conhecimento da genética das pessoas para identificar prematuramente doenças de alto risco para intervir no início ou mesmo antes de a doença aparecer é uma promessa. Esta seria a medicina do futuro, a qual identificaria indivíduos cujo genes aumentariam a susceptibilidade a certas doenças.

Apesar de esta promessa ser amplamente divulgada é ainda precipitado assumir que a genômica médica se tornará rapidamente uma realidade. $O$ conhecimento sobre genes e doenças ainda é muito pequeno para predizer o risco de um paciente desenvolver ou nāo uma doença. Durante algumas décadas, a pesquisa médica identificou 1.500 doenças (chamadas mendelianas), nas quais uma mutaçāo em um único gene prediz o risco de uma pessoa desenvolver a doença.

No entanto, a maioria das doenças é dependente de mais de um gene, ou seja, é poligênica, e isto complica em muito a utilização da genômica na área médica. É verdade que pessoas portadoras dos genes BRCA1 e BRCA2 têm riscos de desenvolver câncer de mama, e aquelas com o gene FAP podem ter câncer colo-retal. Mas estes representam somente a minoria dos casos de câncer.

O nosso mercado farmacêutico, estimado em mais de US $\$ 12$ bilhões/ano, é um grande competidor no mercado mundial. Uma das áreas importantes para o processo de inovação de fármacos é a bioinformática (a integração da biologia, ciência da computação e tecnologia da informação). Os avanços significativos dependem da área de aplicação e integração com bases de dados, simulação, 
modelagem molecular, desenho de novas drogas, entre outras. A bioinformática é fundamental para o desenvolvimento das indústrias de medicamentos e vacinas por diminuir significativamente o custo da inovação de um produto.

A rede brasileira de laboratórios vinculados à genômica e proteômica está distribuida por todo o país. $\mathrm{O}$ mercado mundial com vistas ao desenvolvimento de novos medicamentos pelo uso da bioinformática é de US\$25 bilhões, crescendo a uma base de $15 \%$ ao ano. Em um planeta onde se patenteia tudo, apesar do custo proibitivo da descoberta e desenvolvimento de um novo medicamento, uma droga nova no mercado rende muito mais. A genômica e a proteômica sāo bases da fundação de uma nova pesquisa biomédica voltada à indústria farmacêutica. $\mathrm{O}$ Brasil, possuindo a maior diversidade biológica do planeta e uma comunidade científica competente, pode realmente fazer a diferença nesta nova era se houver estímulo e cooperação público/privado fértil e eficiente.

\section{Notícias sobre o fumo}

Em um estudo conduzido pela doutora Jacqueline Vink da Holanda e publicado no Pharmacogenomics Journal, foi sugerido que o grau de dependência à nicotina e, até mesmo, o número de cigarros que é fumado por dia por uma pessoa, são influenciados geneticamente. Utilizando-se de gêmeos não idênticos, os pesquisadores encontraram quatro marcadores genéticos que parecem estar associados ao vício do fumo. Eles se localizavam nos cromossomos 3, 6, 10 e 14 , sugerindo que pelo menos quatro genes estāo envolvidos neste processo. $\bigcirc$ resultado obtido especialmente no cromossomo 6 revelou que o marcador genético identificava um conjunto de genes de um tipo conhecido como alfa glutationa S-transferase. Estes genes carregam as instruçōes para sintese de enzimas que desintoxicam vários agentes químicos tóxicos, incluindo alguns conhecidos como causadores de câncer. Tais genes são mais ativos nos pulmões e no intestino. Pessoas com deficiência nestes genes demoram a metabolizar a nicotina, aumentando o prazer causado pela droga. É possível, com base neste artigo, que se possa classificar as pessoas que fumam socialmente e aqueles que sāo viciados fisicamente em nicotina.

Em minha opinião, esses resultados devem ser interpretados com muito cuidado, como em todo artigo que relaciona os genes a comportamentos, pois a repetição de tais estudos em populações com valores culturais e morais diferentes é sempre de difícil comprovação. 


\section{A Seqüência das Proteinas e o Proteasoma}

Há alguns anos atrás, imaginava-se que a seqüência dos genes no genoma humano refletia automaticamente, nos produtos funcionais dos genes, a seqüência dos aminoácidos nas moléculas de proteínas, e assim poder-se-ia desvendar os mecanismos responsáveis pela biologia celular e processos patológicos. Entretanto, este cenário nos livros didáticos está se modificando rapidamente.

Recentemente, foi descrito um processo celular inédito que levanta algumas dúvidas sobre o paradigma: a seqüência de uma proteína está baseada na seqüência do seu gene. Por exemplo, quando uma enzima é necessária para que se processe uma etapa do metabolismo celular, segmentos de uma região específica do DNA, chamados éxons, são transcritos em moléculas de RNA. Este é traduzido na seqüência dos aminoácidos que forma a estrutura da proteina enzimática. Quando esta enzima nāo é mais necessária para o metabolismo celular, é degradada por um complexo enzimático conhecido com o nome de proteasoma. Ou seja, numa definição mais ampla, proteasomas são enzimas, encontradas no núcleo e no citoplasma celular, que degradam proteinas que têm a vida curta, bem como proteínas anormais e defeituosas obtidas por erros de tradução ou transcrição, ou mesmo por deficiência gênica. Conseqüentemente, os proteasomas, participando da destruição destas proteínas, influenciam na regulação do ciclo celular.

O que se sabia, anteriormente, era que proteínas com diferenças funcionais podiam ser produzidas por pequenas modificações, como a incorporação de pequenas moléculas aos aminoácidos, quebra ou falha na seqüência protéica, ou omissão de certas regiões do gene alterando a tradução do RNA mensageiro. Entretanto, hoje se sabe que a seqüência de uma proteína pode ser modificada pelo proteasoma. Esta descoberta leva a um novo processamento da proteina e é uma novidade para a função do proteasoma.

A modificação pós-tradução foi descoberta após a análise de seqüências de peptídeos que ativam o sistema imunológico em resposta à presença de células cancerígenas. Estes peptideos antígenos são formados quando os proteasomas fragmentam proteínas específicas em peptídeos e os transportam para a superfície celular, marcando-a para ser destruída pelas reações imunes.

A destruição ou modificação das proteínas demonstrou como um processo celular realmente importante guarda um equilibrio complexo entre as formas úteis e as que vêm a ser dizimadas. A ubiquitina é uma das moléculas que se encarrega de marcar as proteínas que devem ser destruídas. Este processo é 
chamado por alguns pesquisadores como o 'beijo da morte', devido ao fato de as células 'ubiquinadas' serem imediatamente destruidas no proteasoma.

O grupo de pesquisadores que estudou este processo encontrou um antígeno peptídico, com uma seqüência totalmente diferente da seqüência de seu gene, que estimulava o sistema imune a reconhecer e destruir células de melanoma. $O$ mecanismo de ação também ficou esclarecido. $O$ proteasoma age sobre uma proteína recém-sintetizada quebrando-a em três peptídeos. Posteriormente, estes peptídeos são reagrupados de maneira que a proteína antígeno passe a ser reconhecida pelo sistema imune após perder parte de sua sequiência original.

Este processo de modificação pós-tradução é realmente fantástico e pode ter implicações no planejamento de vacinas baseadas $\mathrm{em}$ peptídeos sintéticos, contra a Aids, câncer e outras patologias. Os peptídeos utilizados nas vacinaçōes, por exemplo, podem sofrer modificaçōes estruturais pela ação dos proteosomas, complicando o monitoramento, nos pacientes, das respostas imunológicas a vacinas. Esta descoberta é intrigante pela complicaçāo adicional na identificação do peptídeo antígeno. Até se saber quando, por que e qual é a frequêencia deste processo ocorrer, nāo se pode garantir que o genoma humano responda a todas as questōes relacionadas às seqüências das proteínas sintetizadas pela célula.

\section{Watson e crick}

James Watson e Francis Crick, os pais da biologia molecular, trabalharam no modelo da estrutura de dubla hélice do DNA, na Universidade de Cambridge, e divulgaram a descoberta em um modesto artigo de uma página da revista Nature Reviews Genetics, em 1953. Basicamente, os dois cientistas descreveram a estrutura de dupla hélice e mostraram como os dois segmentos que formam a hélice do DNA se separam,cada um servindo de molde para formar a outra metade, quando a célula se divide. Pela primeira vez, ficava demonstrado que o DNA podia se reproduzir sem mudar sua estrutura.

Pouco anos depois, Watson mudou-se para Cambridge nos EUA, onde, em 1956, tornou-se professor da Universidade de Harvard. Com sua entrada, concomitantemente chegava também a biologia molecular na Harvard, uma disciplina ainda incipiente naquela época. A biologia molecular teve um crescimento explosivo e um avanço extraordinário nos últimos 50 anos. Naquele tempo ela tinha um enfoque reducionista, fracionando os organismos vivos em pequenas estruturas celulares e/ou moleculares. 
Apesar da revolução biológica iniciada em 1953, os cientistas não acreditavam que a biologia molecular fosse suficiente para esclarecer alguns dos processos importantes do que conhecemos como vida. O sucesso da revolução reducionista estava na idéia de que o processo que acontecia em nível molecular forneceria dados para interpretar o mais geral, ou seja, refletiria a atividade celular. Cinqüenta anos após a descoberta da estrutura do DNA e o fortalecimento da biologia molecular, uma nova visão mais integrada para compreender as células, que conhecemos como sistema biológico, está ganhando espaço na ciência. A atenção atual está direcionada, por exemplo, na exploração da complexidade com que as redes de proteínas celulares interagem entre si e com outras moléculas, e não simplesmente na beleza estrutural da dupla hélice.

$\mathrm{O}$ encerramento do $\mathrm{PGH}$, no início de 2004 , revelou a seqüência fria e cansativa das bases de nucleotídeos $\mathrm{A}, \mathrm{C}, \mathrm{T}$ e $\mathrm{C}$ que compõem a longa fita do DNA. A maioria dos segmentos contidos nesta estrutura ainda é completamente misteriosa e obscura para a ciência. Agora, a tarefa para os pesquisadores é estudar como as seqüências dessas bases são agrupadas para constituírem genes ativos, e como estes genes são regulados para produzir proteínas e manter um organismo vivo. Não há possibilidade de saber o que está ocorrendo em uma célula se nāo se entenderem as interaçōes entre seus componentes. Ou seja, somente uma visão ampla e irrestrita dos sistemas biológicos nos mostrará como funciona a biologia celular.

O DNA, que contém as instruções genéticas necessárias para fazer um homem ou qualquer outra forma de vida, é uma molécula longa que está muito compactada no núcleo da célula. Várias regiōes do DNA constantemente são desempacotadas e expandidas, como as dobras do fole de um acordeão, em resposta às necessidades celulares. Quando a molécula do DNA relaxa ou expande, proteínas, chamadas fatores de transcrição, têm acesso ao código genético para ler as instruçōes responsáveis pela síntese de RNA mensageiros, os quais servem de moldes para síntese de proteínas. Quando o DNA está enovelado e compactado, como o fole de um acordeão fechado, os genes não estão acessíveis para as proteínas de transcrição.

Sabe-se que a célula humana coordena, de maneira extremamente eficiente e precisa, a atividade de seus 30.000 genes. Cada uma de nossas células contém a molécula de DNA medindo um total de dois metros, enovelada dentro do núcleo celular, que possui um diâmetro de somente 1/100 de um milímetro. Isto é comparável a empacotar $20 \mathrm{Km}$ de um fio finíssimo de arame dentro de uma bola de tênis. Este enovelamento é importante na ativação e inativação dos 
genes e decide como a célula se comporta, tornando-se uma célula da pele, uma célula hepática ou um neurônio, ou se a célula é saudável ou doente. Sem o desenvolvimento de tecnologias sofisticadas seria impossivel investigar os sistemas biológicos, pois estes envolvem centenas de processos que ocorrem simultaneamente na célula.

Várias técnicas estão sendo utilizadas para analisar o grau de expansão ou compactação do DNA. Geralmente estas técnicas se baseiam em chips de RNA. Entretanto, somente uma pequena fração de genes induz uma síntese de RNA suficiente para ser detectado pelos chips. Recentemente, foi desenvolvida a técnica do chips de cromatina, que dá um detalhe maior de quais genes estão propensos as ativaçōes ou inibiçōes. Com esta técnica, se comparada aos chips de RNA, pode-se conseguir maior informação sobre o número de genes e saber se eles estão ou não induzindo a sintese de RNA. Assim, esta técnica pode nos indicar nāo somente se um dado gene do DNA está presente ou nāo, mas também o grau de compactação ou extensāo do DNA.

A compreensão de como o genoma controla as funçōes celulares nāo diminuiu a importância do enfoque reducionista usado com sucesso por tantos cientistas e por tanto tempo. Por exemplo, os pesquisadores estão aprendendo mais sobre uma proteína chamada condensina, que tem uma importância vital para compactar a molécula de DNA e manter sua integridade estrutural. Assim, a longa fita de DNA mantém seus constituintes compactados através de um complexo especial de condensina, até o período da divisão celular. Os cientistas observaram como o DNA é compactado pelo complexo de proteínas por meio de microscópios magnéticos e vídeos. Assim, observou-se, por exemplo, como o material genético dos organismos vivos se duplica para criar outras gerações de células. A técnica é relativamente simples: moléculas individuais de DNA são fixadas, por uma de suas extremidades, a uma lâmina de vidro, e, pelo outro lado, a uma superfície magnética. Pequenos magnetos distendem e contraem as moléculas. Uma força variável e controlada distende a molécula de DNA, possibilitando avaliar as mudanças na compactação, seguida das interações com o complexo da condensina.

Com base neste teste foi revelado que este complexo de condensina, quando submetido a forças fracas, compacta o DNA. Ao aumentar as forças magnéticas, este processo é revertido, ocorrendo a distensāo da estrutura do DNA. Um outro método excelente para entender a complexidade das redes biológicas é a técnica de microarray para DNA, descoberta na década de 1990, e que permite 
que os cientistas determinem, em uma única vez, os níveis relativos dos genes expressos nas células.

As células rearranjam dramaticamente seus genomas para permitir que os genes sejam expressos. Como mover os móveis em uma casa para arrumar mais espaço, a mudança cromossomal extensiva é acompanhada por estruturas móveis de empacotamento do DNA. Estas estruturas - conhecidas como nucleossomas - são complexos de proteínas presentes em diferentes pontos do genoma. Sabe-se agora que o nucleossoma marca território. Os genes para serem expressos de modo mais eficiente perdem seus nucleossomas que, entretanto, retornam quando os genes são inibidos.

A focalização de um simples gene não permite perceber os processos que estão ocorrendo na célula em um dado momento. É necessário estudar a genômica de um organismo, pois ela significa algo mais integrado para compreender o que está ocorrendo na célula. A genômica é uma ciência altamente comparativa. A tecnologia dos chips pode ajudar no diagnóstico de defeitos genéticos que causam doenças. Células obtidas de um tecido canceroso e um tecido saudável podem ser comparadas e analisadas, dando idéia do que levou o câncer a se desenvolver.

Esta técnica pode também ajudar no entendimento e tratamento de doenças. Os medicamentos podem ter efeitos diferentes em indivíduos que possuem pequenas modificações genéticas. Mas, encontrando o tipo de gene de uma pessoa, pode-se escolher o medicamento e a dose ser determinada para um máximo da efetividade (farmacogenômica). Tais avanços, entretanto, necessitam de novos conhecimentos de como as proteinas interagem na célula. Nos próximos 15 anos, quando um paciente for ao médico, levará o mapa de seu DNA seqüenciado por somente algumas centenas de reais.

\section{Algumas considerações importantes}

O prêmio Nobel Francis Crick faleceu nos EUA, no dia 28 de julho de 2004, aos 88 anos.

Após 13 anos de trabalho, um novo, e talvez o último, relatório do consórcio internacional de laboratórios que decodificaram o genoma humano, publicado na Nature Reviews Genetics, de 21 de outubro de 2004, mostra que o ser humano possui um genoma menor do que se estimava. O consórcio, ao divulgar a seqüência do genoma em 2000, falhou em 147.821 regiões do DNA nos 23 pares de cromossomos humanos. Isto não significa que a seqüência anunciada 
agora seja perfeita. Faltando somente 341 regiōes, cerca de 20.000 genes humanos foram identificados e 5.000 mais necessitam serem revelados. Coincidentemente no mesmo número da revista foi publicado que um peixe biologicamente importante possuía também de 20.000 a 25.000 genes. Vamos também lembrar que um dos modelos favoritos para pesquisa, o verme $C$. elegans, possui 19.500 genes e a planta mostarda, Arabidopsis, tem cerca de 27.000 genes. Aparentemente, em comparação com organismos mais simples, o ser humano se beneficia mais dos genes que ativam a produçāo de proteínas múltiplas do que dos genes que codificam somente uma proteína. Assim, muito da complexidade biológica está baseada na seleçāo de diferentes combinaçōes de proteínas e não em uma simples estrutura seqüencial de aminoácidos.

Em 11 de novembro de 2004, o jornal eletrônico PLOS Biology divulgou um artigo mostrando que regiōes não-gênicas do DNA estavam associadas com o desenvolvimento dos vertebrados. Neste trabalho, foi demonstrado que o genoma humano contém inúmeras regiões do DNA que são regulatórias, o que, aliás, está estimado nos métodos computacional e funcional. As análises da seqüência comparativa de regiões do genoma de diferentes organismos podem identificar similaridades e diferenças no DNA. Em geral, as similaridades na seqüência entre organismos divergentes relacionam-se com as atividades funcionais. Neste artigo, os autores comparam o genoma humano com o de peixe, Fugus rubripes, para identificar aproximadamente 1.400 seqüências altamente conservadas em regiōes não-codificantes do DNA. Respeitando a divergência evolucionária entre as duas espécies, conclui-se que estas sequuências sāo essenciais a todos os vertebrados. Além disso, tais seqüências estão localizadas pertos de regiões que agem como reguladoras do desenvolvimento. Algumas destas seqüências são mais de $90 \%$ idênticas. Apesar disto, não se pode encontrar similaridade nos genomas dos invertebrados.

\section{Investimento e Desenvolvimento de Fármacos}

O governo brasileiro definiu o desenvolvimento de fármacos como uma de suas prioridades para a ciência e tecnologia. Não resta dúvida de que as descobertas de novas drogas e o domínio da tecnologia de produçāo e inovação de medicamentos são pontos importantes para a política de saúde de um país. A população deve ter acesso aos novos medicamentos, que estão cada vez mais caros e de difícil aquisição. No desenvolvimento de medicamentos, a primeira instância de ação deve ser o estímulo à busca de drogas para combater as 
grandes endemias e as doenças degenerativas, vasculares e crônicas que afetam principalmente a terceira idade. A segunda prioridade refere-se a medicamentos de alto valor agregado, como fármacos sofisticados e de última geração e drogas cuja ação depende do perfil genético do paciente.

A inovação de um medicamento é um excelente negócio para a indústria. No entanto, o processo de descoberta de um novo fármaco é lento e depende de grandes investimentos em pesquisa. As grandes empresas investem de US $\$ 600$ a US $\$ 800$ milhões - duas vezes mais que uma década atrás - para colocar um novo medicamento na prateleira de uma farmácia. Este é quase o valor utilizado pela Nasa para colocar um homem na Lua. Estes valores são decorrentes de investimentos, realizados pelas indústrias, de mais de US\$30 bilhōes/ano em pesquisa e desenvolvimento na busca de um novo produto - cerca de 15 vezes mais do que era gasto há 20 anos. Apesar disto, em 2001, foram introduzidos 24 novos medicamentos - metade do número de 1996 . Somente 17 novas drogas foram comercializadas em 2003. Este foi o menor número desde 1983. Algumas grandes empresas há mais de dez anos não conseguem produzir novos fármacos.

Normalmente os medicamentos não são efetivos em $100 \%$ da população, e alguns trabalhos revelam que agem somente em $50 / 60 \%$ dos casos. Nos demais casos, os pacientes não respondem ou os remédios provocam sérios efeitos colaterais. Muitos medicamentos prescritos pelos médicos não agem nos pacientes devido às pequenas diferenças nos perfis genéticos (microgenéticas) entre os indivíduos. A recente revelação da seqüência do genoma humano facilitou a soluçāo da questão genética e abriu uma nova área comercial para os próximos anos, a farmacogenômica, cujo mantra é: fármacos certos, nas doses certas, para os pacientes certos. Ou seja, a farmacogenômica epidemiológica passa por várias especialidades médicas, da genética a estudos estatísticos de doenças e controle, e considera como fatores genéticos influenciam a resposta de uma pessoa a uma droga. Isto é visto como um modo de realizar tratamentos mais seguros e efetivos para cada pessoa individualmente. Apesar de esta área estar ainda no primeiro estágio de desenvolvimento, o seu potencial para melhorar o tratamento de pacientes é enorme e, mais importante, a farmacogenômica pode salvar vidas.

Um belo exemplo foi o experimento realizado com uma droga que reduz os níveis de colesterol no sangue. O DNA de 1.536 pessoas foi analisado para a verificação de 148 snps (polimorfismo que ocorre em um único nucleotídeo) em 10 genes candidatos que agem no metabolismo de lipídios. As variações nestes genes foram examinadas pelas mudanças nos níveis de lipídios ocorridas 
durante 24 semanas de tratamento com a pravastatina. Foi descoberto que indivíduos heterozigotos (que carregavam dois alelos diferentes de um gene), para uma variação genética no gene $\mathrm{HMG}-\mathrm{CoA}$ redutase (enzima alvo da droga), tiveram reduçōes menores de colesterol quando tratados com pravastatina. Este dado é interessante por fornecer uma forte evidência clinica para a 'medicina personalizada' e o uso de genômica para certas terapias.

A maioria dos medicamentos tem ação em proteínas encontradas em diferentes compartimentos e estruturas celulares. Por exemplo, o princípio ativo de um remédio pode interagir com enzimas - substâncias que catalisam as reações bioquímicas - ou com proteínas encontradas nas membranas, que são $30 \%$ de todas as proteínas do organismo. Laboratórios dispendiosos que utilizam cristalografia ou imagens de ressonância nuclear magnética são utilizados para conhecer a estrutura tridimensional da proteína-alvo de uma droga. Conhecendo a proteína, para descobrir um novo medicamento, é necessário desenhar potenciais fármacos adequados à estrutura da molécula-alvo, além de desenvolver sistemas para expressar essa proteina, medir a cinética da reação e incorporaçāo, conhecer a termodinâmica do processo, a estabilidade do complexo fármacoproteína alvo e os possiveis efeitos indesejáveis dos fármacos. Nāo é fácil investigar um novo medicamento antes de ser testado nos animais e nos seres humanos.

Recentemente uma nova técnica conhecida como RNA de interferência (RNAi) permite a inserção nas células de RNAi para inibir a ação de um gene escolhido. O RNAi é um fenômeno que tem evoluido rapidamente com técnica poderosa para silenciar a expressão gênica em células eucarióticas. De imediato, essa técnica foi vista como poderosa para tratamento de doenças, como o câncer, diabetes e outras patologias. Os cientistas descobriram que, na célula, moléculas pequenas de RNA se ligam a moléculas maiores responsáveis pela síntese de proteínas. Em experimentos com C. elegans, os pesquisadores mostraram que as moléculas de RNA sintetizadas no laboratório podiam unir-se a RNAs interferindo no componente funcional desta molécula, daí nasceu o nome RNAi.

Estima-se que $30 \%$ de todas as doenças genéticas humanas envolvem erros nos RNAs. Assim, inúmeras patologias que se relacionam com defeitos nos genes ou mesmo descontroles genéticos poderiam ser silenciadas através o RNAi. A diversidade de sua aplicação faz do RNAi uma ferramenta essencial para pesquisadores envolvidos na caracterização da função de um determinado gene, na análise de uma via importante para ação de um medicamento ou mesmo na validação de alvos terapêuticos. $\mathrm{O}$ uso desta tecnologia gera inúmeras oportunidades e desafios. 
Não resta dúvida de que o potencial desta tecnologia no campo da genômica funcional e na descoberta de novos medicamentos é promissor. Por exemplo, o RNAi pode suprimir genes que causam tumores diminuindo o desenvolvimento de câncer. Entretanto, várias barreiras necessitam ser ultrapassadas para utilização desta técnica para pesquisa e aplicação clínica.

As moléculas de RNAi nāo funcionam em bactérias utilizadas normalmente em experimentos. Também elas não podem ser aplicadas sem interferir nas células, e os genes não permanecem suprimidos por longo tempo. Para contornar esses problemas, pesquisadores estão mudando a composição química das moléculas convencionais de RNA usadas no RNAi e combinando a fita simples de RNA com a fita simples complementar do DNA para criar pequenas moléculas híbridas de RNA-DNA.

Estes híbridos são mais estáveis que os RNAi, passivamente penetram nas células por um mecanismo ainda não conhecido e permanecem intactos no interior das células. Assim, as moléculas híbridas de RNA-DNA são mais eficientes que os RNAi, seus efeitos demoram 10 vezes mais dos que os gerados pelas moléculas convencionais, são mais baratas para serem produzidas e são ativas em bactérias e vírus. As moléculas híbridas podem localizar um dano ou uma pequena alteração em um gene, entre seis bilhōes de nucleotídeos contidos em uma única célula, e torná-lo silencioso. É bom lembrar que os genes agem no organismo através da expressão de proteínas e enzimas específicas que cada gene codifica. $O$ código genético contido na seqüência de DNA é transcrito para RNA e finalmente traduzido em polipeptídios - proteínas, enzimas ou hormônios peptídicos. Uma doença genética é resultante de uma mudança no(s) gene(s), gerando produtos genéticos anormais.

O gene inibido pelo RNAi não produz a proteína pela supressão de sua expressão. Esta estratégia de intervenção não está limitada à inibição de genes endógenos - aqueles que ocorrem naturalmente na célula. Ela pode ser também usada para silenciar genes estranhos, tais como aqueles de um vírus ou uma bactéria invasora, assim protegendo o organismo de uma infecção.

Em resumo, para utilizar moléculas híbridas de RNA-DNA, deve-se inicialmente identificar a seqüência de nucleotídeos no gene-alvo. Então, uma pequena seqüência de cerca de 20 nucleotídeos é sintetizada para identificar a sequêencia genética a ser silenciada. Quando esta molécula híbrida for inserida em uma célula, ela se liga seletivamente no RNAm da seqüência-alvo, bloqueando sua capacidade de expressar o produto. A experiência mostra que 
moléculas híbridas, tendo como alvos genes que causam câncer, inibiram o crescimento rápido das células cancerígenas e não causaram efeito deletério nas células normais próximas ao câncer.

A indústria de biotecnologia, tão criticada por cientistas conservadores, movimenta algo em torno de US\$30 bilhões/ano, produzindo mais de 160 medicamentos e vacinas, e possui cerca de 370 drogas e imunobiológicos em vários estádios de testes. A prioridade no desenvolvimento de fármacos depende de uma política industrial forte e agressiva e de grandes investimentos em pesquisa básica e aplicada e de reconhecer que países que negligenciam a produção própria de medicamentos amargam uma perene condição de dependência tecnológica. Há que se investir para fazer a diferença.

\section{RNAi: sobre a descoberta da nova técnica}

A descoberta de RNAi foi em 1998 quando os cientistas revelaram que pequenas fitas duplas de RNA podiam efetivamente se ligar a genes específicos. Logo se imaginou o potencial revolucionário dessa técnica no tratamento de inúmeras doenças. A chamada terapia por RNAi é considerada uma das descobertas mais importantes nos últimos tempos para a ciência biológica devido ao seu poder de silenciar genes indesejáveis relacionados a doenças deixando os demais genes intactos. No entanto, se os RNAis forem dissolvidos no sangue, por exemplo, eles não conseguem penetrar nas células. Mas esta terapia será útil para a medicina se for administrada pelos métodos da medicina convencional.

Dados publicados na segunda semana de novembro de 2004 pela revista Nature Reviews Genetics demonstraram que a técnica de RNAi silenciava o gene responsável pela síntese de apolipotroteína $\mathrm{B}$, diminuindo sua concentraçāo no sangue aproximadamente em $70 \%$ e, conseqüentemente, reduzia a mais da metade os níveis de colesterol no sangue de camundongos. O RNAi ligava-se a proteínas do sangue, o que aumentava sua estabilidade por 15 vezes.

A idéia é que a população de moléculas lipofílicas, como a de colesterol, agiria como cavalo de Tróia para colocar RNAi no interior das células. Os pesquisadores ligaram RNAis a moléculas de colesterol que rapidamente são absorvidas pela célula. Ironicamente, a molécula de colesterol carreava um RNAi para silenciar um gene responsável pelo alto nível de colesterol no sangue. As moléculas de colesterol-RNAi reduziram $37 \%$ o nível de colesterol em camundongos. 
Este é mais um passo em direçāo ao uso clínico de RNAi. A beleza desse resultado está em sua simplicidade. No entanto, ainda sāo necessárias várias experiências para monitorar as aplicaçōes diretas e sistêmicas de RNAi em doenças, como as cardiovasculares, diabetes, obesidade, hepatite, câncer e outras patologias, e para verificar os potenciais efeitos colaterais, quanto tempo o efeito da droga persiste sem a necessidade de inoculaçōes adicionais, ou seja, revelar a eficiência da terapia por RNAi. 



\section{2 \\ Genômica comparada}

A genômica comparada envolve o estudo de genomas de diferentes espécies e as possiveis alteraçōes biológicas causadas por pequenas modificaçōes quando comparadas as estruturas dos genes, o que leva a um melhor entendimento de um processo patológico ou mesmo do processo evolutivo.

\section{Diferenças entre Primatas: homem e chimpanzé}

Alguns pesquisadores acreditam que para compreender a natureza humana deve-se entender o comportamento dos primatas. As interações sociais e a organização das comunidades dos primatas mais evoluídos, em teoria, podem levar às raízes evolucionárias de nossas próprias relações sociais. A partir do século XVII até recentemente, nossa familiaridade com o chimpanzé se deve à semelhança dos corpos e à ignorância do que representa o DNA.

Após vários séculos estudando os macacos, ficamos familiarizados com cada uma das diferenças entre os primatas. No entanto, a emergência das comparaçōes moleculares, nos anos 60, e as tecnologias do DNA, nos anos 80 do século passado, revelaram novas maneiras de comparar as espécies. A comparação linear de polímeros, como as proteínas, que possuem aminoácidos como componentes básicos estruturais, ou os DNAs, compostos de cadeias de nucleotídeos, indicaram um enfoque tabular para a evolução.

$\mathrm{Na}$ era da genômica, os cientistas tornaram-se adeptos às seqüências genômicas e buscaram nelas explicação para a evolução humana. $O$ segredo de como diferimos de nossos 'parentes' evolucionários, os primatas, e de como os primatas diferem entre si, pode estar contido em nosso genoma e nos genomas dos primatas não-humanos. A comparação de genes dos primatas nos leva à compreensão da base genética das vias bioquímicas que distinguem as espécies de primatas dos seres humanos. 
Os mecanismos genômicos e processos mutacionais mais importantes para o entendimento dos processos evolucionários, estudados nos últimos 25 anos, demonstraram ser mais complexos do que se pensava. Os mecanismos básicos utilizados para criar novos genes e processos bioquímicos são a duplicação, transposição e recombinação ilegítima dos genes, as quais resultam no aumento do número de cópias de genes e diferenças qualitativas entre os genomas considerados. As duplicações gênicas, bem como suas reduções, que são específicas para cada espécie, ou linhagem, podem ser características únicas para uma determinada espécie de primata.

Comparando os genomas de quatro diferentes primatas evoluidos, foram identificados genes que representam uma significante maioria das principais cópias de genes e que foram modificados em processos que ocorreram nos últimos 15 milhões de evolução da espécie humana e de outros primatas. Foram encontrados mais de mil genes que sofreram mudanças específicas no número de cópias no ser humano, chimpanzé, gorila e orangotango. Destes, a expressão de 134 estava aumentada somente nos seres humanos.

Os primatas mais evoluídos demonstraram mais aumento que diminuição dos números de cópias desses genes. Isto é indicativo de uma evolução de novas funçōes e habilidades desses animais. Estes dados foram mais expressivos para os seres humanos, incluindo o número de genes envolvidos na estrutura e função do cérebro humano, que contribuem para as habilidades cognitivas e únicas do homem.

A distribuição dos genes modificados no genoma não era randômica. Vários genes que apresentavam variações no número de cópias estavam localizados em aglomerados de genes propensos à instabilidade. Estas regiões têm uma história evolucionária dinâmica e são conhecidas por estarem associadas a doenças humanas. Isto sugere que tais regiōes podem ter sentido duplo: de um lado como adaptações dos processos evolucionários, de outro, a mesma instabilidade levando a doenças genéticas.

As primeiras comparaçōes realizadas entre os genes de dois primatas, homem e chimpanzé (Pan troglodytes), revelaram que há mais diferenças entre esses animais do que se imaginava. A primeira delas foi a rápida evoluçāo de genes ligados à audição, ao olfato e à digestão de proteínas. No entanto, esse desenvolvimento não aconteceu no chimpanzé, mas sim no homem. Os dois animais compartilham quase $99 \%$ do material genético. Esperava-se que na diferença de cerca de $1 \%$ estariam os traços que marcariam a diferença entre o 
macaco e o ser humano. Foram analisadas 7.645 seqüências de genes de chimpanzé que foram comparadas com genes compartilhados com o homem e o camundongo. Dos 7.645 genes compartilhados, 1.547 genes humanos e 1.534 genes de chimpanzé experimentaram transformaçōes relativamente rápidas, que provavelmente deram uma vantagem à sobrevivência.

Este estudo que começou com praticamente os 23.000 genes, caiu para 7.645, devido à necessidade de assegurar o alinhamento dos genes humano, do chimpanzé e do camundongo. Genes também são afetados pela seleçāo natural e pelo meio ambiente. Essas mutaçōes podem ser neutras, negativas ou positivas. Nesse último caso, fazem surgir mudanças que facilitam a sobrevivência.

A distinção é que o olfato, a audição e o catabolismo de aminoácidos mostraram um excesso de genes sendo positivamente selecionados. A maneira como os genes são regulados e como as proteínas são sintetizadas pelo organismo também é importante para definir a diferença entre o chimpanzé e o homem. Em algumas análises realizadas, os dois genomas foram também comparados com o genoma de camundongo, para tentar encontrar genes que evoluíram mais rapidamente no ser humano. Neste sentido, as seguintes perguntas podem ser feitas: quais são os genes que nos faz humanos? Ou melhor, quais foram os genes obtidos da seleção natural que resultam nas diferenças entre o homem e o chimpanzé?

É possivel que nos genes - e em sua regulaçāo - se concentrem os seis milhões de anos de evolução que separam o homem do chimpanzé. A evolução rápida de genes ligados à audiçāo pode estar vinculada ao desenvolvimento da linguagem, uma das características que separa o homem dos animais. Os genes que causam o catabolismo de proteínas podem ter ajudado quando houve uma mudança de dieta na pré-história. Há os que correlacionam a expansão do cérebro com o aumento de consumo de carne (proteínas).

As diferenças nos genes que controlam a produção de receptores nas células do olfato podem ser devidas aos chimpanzés usarem mais o olfato no dia a dia do que o ser humano. No entanto, a expansão de genes ligados a esse sentido ainda é um mistério. Pode estar associada ao comportamento sexual, ou a alguma função desconhecida. A evidência de a seleção natural ter favorecido mais o humano do que o chimpanzé, no sentido do olfato, é devida à importância deste sentido para encontrar o alimento e para o acasalamento.

Em adição à maior percepção do olfato, diferenças no metabolismo de aminoácidos também parecem afetar o chimpanzé e o homem, principalmente 
em suas habilidades de digerir proteínas. É claro que o ser humano ingeria mais proteínas durante mais tempo. Isto deve ter ocorrido há aproximadamente dois milhões de anos em consonância com uma grande variação climática. Genes relacionados à fertilização, à gestação, ao crescimento dos ossos longos e à distribuição de pêlos também apresentaram diferenças.

Não se pode evitar a tentação de imaginar uma diferença mais complexa: a habilidade de falar e compreender a linguagem. Talvez alguns desses genes capacitaram o homem a entender como a linguagem funciona, nāo somente no cérebro, mas também na audição. Na realidade há duas pequenas, mas importantes, diferenças entre genes individuais. Por exemplo, uma está no gene FoxP2, relacionado com a fala e linguagem. A outra diferença envolve os genes do olfato que codificam receptores das narinas. Progressivamente o ser humano está perdendo uma grande parte desses genes e tornando-se menos acurado em detectar o cheiro.

Este processo começou há cerca de 3 milhões e, possivelmente, continuará por outros 1,8 milhōes de anos. Assim como a nossa habilidade na linguagem melhorou nos últimos 200 mil anos, nosso sentido de olfato está se deteriorando. Por outro lado, um ponto que tem intrigado os pesquisadores é porque os chimpanzés são imunes a várias doenças humanas, como a malária e a Aids. Se, ao investigar as variações dos genes do sistema imune do chimpanzé e do homem, certamente se avançará na compreensão dos processos envolvidos na patologia dessas doenças, o que poderá nos levar ao desenvolvimento de melhores medicamentos?

Uma outra evidência de mudança na seleção está nos genes que codificam uma proteína obscura existente na membrana tectorial do ouvido interno. Uma forma inata de surdez é causada por uma mutação neste gene, conhecido com alfa-tectorina. Uma anomalia neste gene resulta em audição insuficiente, alguma coisa como não distinguir o som emitido por um violinista, como Turíbio Santos, de um emitido por um tocador de violão comum.

Também foi observada sistematicamente a atividade gênica nos cérebros do chimpanzé, ser humano, orangotango e macacos, e, quando comparadas, verificou-se grandes diferenças. Em uma regiāo particular do cérebro, aproximadamente $10 \%$ dos genes diferiam entre o homem e o chimpanzé. A distinção entre as duas espécies também pode ser devida à importância funcional de diferentes níveis de expressão genética cerebral. Este racional mostra que a biologia do homem e do chimpanzé não difere devido a um gene 
em particular. No entanto, nāo impede que várias hipóteses possam ser testadas para se entender que somente $1 \%$ da seqüência de DNA é que nos faz diferentes de um chimpanzé.

Todavia, devemos lembrar sempre que a seqüência do DNA é uma entidade unidimensional e induz sempre comparaçōes lineares e não espaciais. Os genes que regulam a produçāo do fêmur humano e do chimpanzé podem ser $99 \%$ idênticos, mas é impossivel dizer se os ossos femurais são mais ou menos semelhantes entre as duas espécies.

É sempre bom lembrar que duas seqüências de DNA geradas randomicamente devem ser $25 \%$ idênticas, devido ao fato de que o DNA é uma seqüência de somente quatro bases. Como todos os organismos multicelulares se desenvolveram de um simples ancestral comum, as semelhanças entre seus DNAs devem ser maiores do que $25 \%$. Em outras palavras, o ser humano e uma mosca têm muito em comum em termos genéticos, apesar de serem totalmente diferentes fisicamente. Este é um belo exemplo de uma comparação grosseira entre o DNA de duas espécies.

Assim, este fato aparente da natureza - a similaridade genética entre o homem e o macaco - é construído pela nossa cultura. Isto nāo quer dizer que este fato seja falso, e sim que seu significado é menos óbvio do que parece. Culturalmente procura-se dar sentido a vida, e a ciência fornece informaçóes para construção do nosso lugar no planeta. No entanto, como em qualquer sociedade, usamos essas informaçōes para explicar nossa existência, que é influenciada fortemente pelas nossas idéias não cientificas e por ideologias da hereditariedade.

\section{Semelhanças e dessemelhanças}

A pergunta continua: o que faz a diferença entre o homem e o chimpanzé? Por que tem sido um mistério para a ciência o fato de o ser humano ser semelhante na aparência e no comportamento com o chimpanzé? A revista Nature Reviews Genetics, de novembro de 2004, publicou um artigo sobre a evolução do cérebro humano sugerindo que o homem e o chimpanzé pensam de maneira diferente. Eu, particularmente, acredito nisto. Após uma extensa análise dos dois genomas, os pesquisadores demonstraram o porquê de o cérebro humano ter evoluído de maneira diferente do cérebro do chimpanzé. Como as seqüências dos DNAs entre eles são muito semelhantes, a hipótese levantada é a de que as diferenças ocorrem entre os niveis de expressão genética 
e de como os genes são regulados. Ou seja, o número de genes ou a diferença na seqüência de DNA entre os dois animais nāo são importantes, e sim como e quando estes genes são expressos ou desativados.

Utilizando-se da técnica de microarranjos - microarrays -, os cientistas exploraram e compararam o genoma do ser humano e do chimpanzé examinando quais genes são expressos ou não ativados em diferentes órgãos. Os dados encontrados permitiram concluir que a regulaçāo genética era diferente quase que exclusivamente no cérebro, e não em outros órgãos como o fígado e o coração. Isto sugere que as diferenças genéticas são específicas para o cérebro e associadas como nossa função cognitiva. Além disso, também foi demonstrado que os genes eram mais freqüentemente desligados, ou desativados, no cérebro humano do que no chimpanzé. Em uma linguagem mais popular, parece que o cérebro humano é como um computador de última geração e o do chimpanzé é mais parecido com um modelo XT.

Os genes que regulam o desenvolvimento e função cerebral evoluíram mais rapidamente nos seres humanos que nos primatas não-humanos e outros mamíferos devido ao processo único de seleção natural que ocorreu na linhagem dos humanos. Pesquisadores anunciaram na revista Cell, de 29 de dezembro de 2004, que o desenvolvimento das habilidades cognitivas dos seres humanos não ocorreu devido a mutações acidentais, e sim em decorrência de um grande número de mutações favorecendo uma seleção intensa e excepcional destas habilidades.

Os pesquisadores examinaram 214 genes envolvidos no desenvolvimento e função cerebral de quatro espécies de primatas: humanos, macacos (do Velho Mundo), rato e camundongo. É bom lembrar que os primatas se separaram dos roedores a cerca de 80 milhões de anos, e os humanos dos macacos há 2025 milhões de anos; os ratos divergiram dos camundongos a cerca de 20 a 23 milhões. Para cada um desses genes cerebrais foram identificadas mudanças que alteravam a estrutura da proteina resultante, bem como genes que não afetam a seqüência das proteinas. A seleção evolucionária focalizava somente os genes que alteravam a estrutura protéica. Trocas em um gene que não muda a proteína indicam uma mutação dentro do esperado, da normalidade, ou seja, mutaçōes randômicas basais conhecidas como relógio molecular genético. A relação entre estes dois tipos de mudanças fornece uma estimativa da pressão sobre a seleçāo natural levando à evolução do gene. Assim, os pesquisadores chegaram à conclusão de que os genes relacionados com o cérebro evoluíram mais rapidamente nos seres humanos que nos macacos e estes mais que nos 
ratos e camundongos. Adicionalmente, a linhagem humana possui uma maior mudança nas proteinas que os macacos, entre eles, os chimpanzés. Possivelmente, essas mudanças evolutivas rápidas foram as responsáveis pelo desenvolvimento $\mathrm{da}$ linguagem e inteligência nos seres humanos.

\section{O homem e seu melhor amigo}

Os mamíferos existentes no planeta, em algum ponto da escala evolutiva, tiveram um ancestral comum. A descoberta que os seres humanos são geneticamente próximos dos cães e dos camundongos fez as pessoas olharem com mais respeito a vida dos animais. Os cães divergiram do ancestral comum transformando-se em uma espécie independente há aproximadamente 95 milhões de anos. Apesar disso, em termos da genética comparativa, esta relação não é tão lógica assim. O cão é geneticamente mais similar ao ser humano do que este é do camundongo, que divergiu do homem há 87 milhões de anos. Ou seja, nós estamos mais próximos dos cães do que dos camundongos e os ratos, quando se compara o conteúdo e a estrutura genética dessas quatro espécies de mamíferos.

Desde o início dos estudos de genética molecular, mais de 150 espécies tiveram o genoma seqüenciado. A maioria dessas espécies era de microorganismos. Somente agora está sendo seqüenciado o genoma de uma espécie de convivência tão próxima ao ser humano. A relação ancestral entre o ser humano e o cão tem sido caracterizada como um longo experimento de genética, pois se iniciou quando o ser humano cruzava diferentes raças de cāes para conseguir um animal que pudesse segui-lo, desse melhor proteção e que fosse ativo caçador.

Mas a ciência genética canina está apenas em seu começo. $O$ cão, domesticado há cerca de 10.000 anos, logo após a exploração agrícola ser estabelecida, teve o primeiro rascunho de seu genoma divulgado. Existem mais de 400 linhagens distintas de cães, as quais fornecem aos caninos uma enorme variedade de diferenças físicas e comportamentais à disposição de exploração genética.

Dentre essas espécies, um poodle, macho, chamado Shadow, e uma fêmea boxer, conhecida pelo nome de Tasha, foram escolhidos para reservar seu lugar na história, tornando-se a quarta espécie de mamífero, após o ser humano, rato e camundongo, a ter o genoma mapeado. Para a crescente comunidade de geneticistas de cães, dos criadores aos pesquisadores veterinários, esta revelação foi um grande passo, pois, tendo a seqüência genômica, diminuirá o tempo na pesquisa por genes do comportamento do animal, por exemplo. 
O primeiro rascunho do genoma canino demonstrou que este animal possui aproximadamente 2,4 bilhões de pares de base, número ligeiramente inferior quando comparado com os 2,9 bilhöes de bases que estruturam o genoma humano. É sempre conveniente lembrar que o cão possui 78 cromossomos (pacotes de DNA que se encontram no núcleo de cada célula) e o ser humano 46 . Com $85 \%$ do genoma seqüenciado foram encontrados 650 milhōes de pares de bases comuns ao cão e ao ser humano. De um total de 24.567 genes humanos já conhecidos, 18.473 genes são também encontrados no genoma do cão.

A preservação das seqüências entre os dois genomas não está restrita aos genes, mas inclui também uma grande fração dos genomas de função ainda desconhecida (DNA lixo). A razão de as seqüências serem altamente conservadas em diferentes espécies após milhōes de anos de evolução divergente é um dos principais desafios atuais para os biologistas. No entanto, uma grande diferença, já esperada, foi encontrada: o genoma do cão codifica uma maior variedade de proteínas envolvidas no sentido do olfato do que os genes humanos.

No genoma do cão foram identificados 974.400 single nucleotide polymorphisms (snps), mudança em um único nucleotídeo. Essas variações genéticas de uma só letra são importantes para a compreensão de genes que contribuem para as doenças. Curiosamente, o cão possui cerca de 400 doenças genéticas, sendo a maioria delas homólogas às doenças existentes no ser humano. Não resta dúvida de que o conhecimento do genoma do cão torna a compreensão do processo evolutivo mais fascinante, além de entendermos mais as histórias e origens de doenças comuns entre as 4.600 espécies de mamíferos existentes.

O campo da genética de cães tem crescido pelo uso de novas tecnologias derivadas do conhecimento do genoma. Várias destas ferramentas moleculares têm sido utilizadas para investigar doenças genéticas caninas, entre elas a desordem na coagulação do sangue, displasia, cegueira e epilepsia. A idéia dos criadores de cães é usar estas tecnologias para ajudar na criação de cães mais saudáveis ou com pêlos da cor desejada.

Os criadores de cāes também estão investigando a possibilidade de usar marcadores genéticos para melhorar o temperamento do animal. Por exemplo, pode-se combinar o genoma de um labrador com um poodle para criar um labradoodle, o qual teria a inteligência e pêlos hipoalergênicos de um poodle e a relação amigável de um labrador. Ou seja, pela engenharia genética será possível desenvolver animais que sejam mais confiáveis e menos violentos e nervosos. 


\section{Do Homem, do Camundongo e do Rato}

Já mostramos que os mamiferos tiveram um ancestral comum em algum ponto da escala evolutiva. O ser humano divergiu do camundongo a cerca de 87 milhōes de anos e do rato há 80 milhōes. Este periodo não está muito distante da época em que os dinossauros foram extintos, fato este que favoreceu a propagação dos animais mamíferos no planeta. Assim, na árvore evolutiva dos mamiferos, o ser humano um dia compartilhou a mesma linhagem desses roedores.

Os ratos nāo devem ser considerados simplesmente uns camundongos maiores. Esses animais diferiram evolu tivamente entre si mais do que o homem divergiu do macaco. Os dados do genoma do rato e do camundongo confirmaram que eles divergiram, entre 12 e 24 milhōes de anos, de um ancestral comum, para formarem estas duas espécies. Após esta divergência evolutiva, cerca de 50 rearranjos cromossomais ocorreram em cada uma das linhagens desses roedores.

Quando comparadas às sequiencias dos genomas do homem, do camundongo e do rato, abre-se uma nova maneira de investigar, facilitando o estudo do tratamento das doenças, desenvolvimento de novos medicamentos e drogas $\mathrm{e}$ evolução dos animais mamíferos. A disponibilidade para trabalhar comparativamente com os três genomas nos oferece a habilidade de triangular informações e analisar o que é similar ou não, interpretando e resolvendo detalhes da biologia humana.

O ser humano divide $99 \%$ de seus genes com o camundongo e possui até genes que poderiam desenvolver uma cauda. De fato, somente cerca de 300 genes são exclusivos para cada uma dessas espécies. Por outro lado, a regiāo não-codificante do DNA dessas espécies (DNA lixo), separada evolutivamente por dezenas de milhōes de anos e milhões de gerações, é altamente e estranhamente conservada. $\mathrm{O}$ significado disto no processo evolutivo ainda nāo está claro. Sabe-se que certos segmentos do DNA lixo participam da reuniāo e organização da estrutura dos genes.

Entretanto, recentemente, os pesquisadores 'engenheiraram' geneticamente células embrionárias e desenvolveram camundongos que apresentavam 2,3 milhōes de bases do DNA (das 2,7 bilhões de pares de bases que formam o genoma co camundongo em regiões não-codificantes). Comparando os animais alterados geneticamente com camundongos normais, os pesquisadores não observaram diferenças na viabilidade, desenvolvimento e longevidade. Assim, é importante salientar que as modificações genéticas não alteraram a biologia do animal. Esses dados necessitam ser mais profundamente analisados. 
As principais diferenças entre o homem e o camundongo aparecem em áreas dos genomas que governam a imunidade, desintoxicaçāo, olfato e sexo. Isto faz sentido se considerarmos onde estes roedores vivem, como eles encontram alimentos e o número de filhos que eles podem gerar. Cerca de $40 \%$ do genoma desses mamiferos vêm do último ancestral comum. Este percentual equivale a um bilhão de bases encontradas próximas aos genes e seus sinais regulatórios. Comparando os genomas dessas três espécies, pode-se observar quantas seqüências comuns do DNA são compartilhadas pelo camundongo, rato e ser humano. Por exemplo, camundongos e ratos possuem a mesma distância evolutiva, se comparados o cromossomo $\mathrm{X}$ entre o rato e ser humano e o ser humano com camundongo.

Documentos históricos revelam que os ratos vêm sendo usados como animais. modelo de laboratório desde 1828. Somente 100 anos depois os camundongos ficaram em moda, provavelmente, por serem menores e mais fáceis de serem criados. Por razōes técnicas, o camundongo tornou-se o animal experimental dominante para os estudos genéticos, principalmente aqueles que envolvem retiradas ou inserção de genes. Já foram desenvolvidos camundongos com sistema imune similar ao do humano, o que torna possivel estudar doenças que desenvolvem os seres humanos. Este é um modelo que fornece uma nova ferramenta para investigar agentes patogênicos que especificamente atacam o sistema imune humano, bem como para testar potenciais intervençōes terapêuticas.

Como animal de laboratório, o rato tem vantagens sobre o camundongo. Ele é mais esperto, ágil, serve como um melhor modelo rotineiro na pesquisa biomédica para determinar a toxicidade de fármacos em desenvolvimento, antes de serem testados nos seres humanos. Também são usados para estudos de câncer, diabete e doenças cardiovasculares (hipertensão), desordens psiquiátricas, regeneraçāo neural, cirurgia, transplantes e doenças auto-imunes.

Os rearranjos cromossomais, bem como outros tipos de mudanças no genoma, sāo menores nos primatas do que nos roedores, indicando que as transformaçôes evolucionárias ocorreram mais rapidamente nestes animais. O rato possui 21 pares de cromossomos, o camundongo 20 e o homem 23 pares. Entretanto, uma análise comparativa entre os cromossomos dos três últimos mamíferos revelou que cerca de 280 regiōes contêm seqüências similares, chamadas blocos sintênicos, distribuídas por todo cromossomo.

O genoma do rato possui aproximadamente 2,75 bilhōes de pares de base, sendo assim menor do que o do ser humano, o qual tem cerca de 2,9 bilhões e, 
um pouco maior do que o genoma do camundongo, que possui 2,6 bilhōes de pares de bases. Entretanto, o genoma do rato contém aproximadamente o mesmo número de genes que o ser humano e o camundongo, ou seja, entre 25 a $30 \mathrm{mil}$ genes. Quase todos os genes humanos associados com doenças são compartilhados com o genoma do rato e do camundongo. Uma análise mais refinada revelou que alguns aspectos da evolução do genoma do rato parecem estar acelerados quando comparados com o do camundongo.

Devido a uma expansão rara e rápida de algumas famílias de genes selecionados, os ratos apresentaram genes não encontrados em camundongos, incluindo genes envolvidos na imunidade, produção de feromônios, degradaçāo de proteínas e deteç̧ão e neutralização de substâncias tóxicas. Por exemplo, certas regiōes do genoma do rato evoluíram mais rapidamente dando a esse animal um sentido de olfato maior, para uso na deteç̧ão de perigo, marcação de território e escolha de casais. Os ratos possuem cerca de 2.070 genes codificantes de receptores de cheiro, o que significa um terço a mais do que os camundongos. As mutações que desenvolveram esta diversidade ocorreram provavelmente randomicamente, mas deram algumas vantagens aos ratos que podem viver em uma variedade do pior habitat existente em todo o planeta.

Recentemente, pesquisadores estão trabalhando com animais híbridos, conhecidos como quimeras - da criatura grega mítica com cabeça de leão, corpo de ovelha e cauda de serpente. Estes animais estão permitindo que os cientistas vejam, pela primeira vez, como uma célula humana nascente e órgãos maduros interagem - não em uma placa de vidro, mas dentro do organismo de um animal vivo. Talvez, um dos mais ambiciosos projetos utilizando-se de quimera veio da Universidade de Stanford. Irving Weissman tentou desenvolver o primeiro camundongo com um sistema imune próximo ao do humano. Posteriormente, sua equipe injetou células-tronco neurais humanas em fetos de camundongos, desenvolvendo animais com $1 \%$ do cérebro humano. Dissecando camundongos em diferentes dias após este procedimento, os pesquisadores viram como as células nervosas se moviam, multiplicavam e faziam conexões com células do camundongo. Agora, este grupo pretende adicionar células-tronco que possuem defeitos causadores da doença de Parkinson e investigar se esta doença aparece nas primeiras etapas do desenvolvimento humano, além de desenhar novos medicamentos e testá-los em animais quimeras, de modo não possivel em pacientes.

Isto faz lembrar a história da "Ilha do dr. Moreau", escrita em 1986 por H. G. Wells, na qual o referido doutor desenvolve criaturas que são parte animal 
e parte humana. Agora isto não é mais uma ficção, as quimeras são criações reais de cientistas reais, procurando esclarecer a complexidade da biologia.

\section{A galinha vermelha da china}

Um consórcio internacional publicou na revista Nature Reviews Genetics, de 9 de dezembro de 2004, a sequiência do genoma da galinha vermelha selvagem chinesa (red jungle fowl, Gallus gallus). Esta ave foi obtida de uma criação desenvolvida em UC Davis pelo geneticista Hans Ablanalp, professor emérito de ciência aviária, nos primeiros anos da década de 1950. Assim como o lobo é ancestral do cão, o Gallus é considerado ancestral das demais espécies de galinhas. Este animal foi a primeira ave, o primeiro animal de valor agrícola comercial e o primeiro descendente do dinossauro a ter seu genoma seqüenciado. O seu genoma contém 39 pares de cromossomos, com um DNA contendo de 20.000 a 23.000 genes. Apesar do tamanho do genoma ser 2/3 menor do que o do humano, $60 \%$ dos genes codificaram proteínas existentes no genoma humano. A diferença na amostra total de DNA reflete uma reduçāo substancial do genoma referente a duplicações gênicas, bem como a poucos pseudogenes no genoma da galinha. Este animal parece ser a única espécie de vertebrado, cujo genoma tenha sido seqüenciado, que perdeu mais genes do que ganhou no processo evolucionário.

De fato, a análise comparativa entre dois DNAs revelou que o ser humano possui genes relacionados com os genes da galinha produtores de proteínas da casca do ovo. Obviamente, estes genes têm um papel da formaçāo de ossos dos humanos. Foi com certa surpresa que os pesquisadores verificaram que as galinhas possuem mais genes relacionados com a sensação do odor do que era esperado.

Isto sugere que estes animais detectam o cheiro de uma forma mais elaborada do que se acreditava. Por outro lado, estas aves possuem menor número de genes relacionados ao paladar do que as pessoas. Finalmente, não foi surpreendente que as galinhas não apresentaram nenhuma versão dos genes humanos relacionados à produçāo de leite, saliva e dentes.

Como todas as aves, as galinhas são descendentes dos dinossauros no meio do período Mesozóico. Aparentemente, o ser humano e a galinha dividiram um ancestral comum há 310 milhões de anos - mesmo antes de os dinossauros emergirem - comparados com os 80-87 milhōes de anos desde que os humanos e os roedores se separaram na árvore evolucionária. 
Os primeiros pássaros apareceram 150 milhōes de anos depois. As galinhas foram domesticadas na Ásia a cerca de 8.000 anos. A criação intensiva de galinhas iniciou-se na metade do século passado, levando ao desenvolvimento de linhagens altamente especializadas, as quais produzem mais carne e ovos que os animais antigos. Hoje bilhōes de galinhas sāo criadas por ano. O melhoramento de galinhas representa um dos mais extraordinários exemplos de evolução dirigida.

Os segredos do genoma de galinha podem levar à produçāo de superaves que produzirão mais ovos e mais carne e serão mais resistentes a doenças. Este DNA poderá esclarecer muitas dúvidas sobre doenças, como a gripe aviária que causou uma epidemia grave no sudeste da Ásia. A Organizaçāo Mundial da Saúde (OMS) acredita que a gripe aviária se espalhará pelo planeta, podendo transformar-se em um agente perigoso que poderia matar milhares de pessoas.

Com o conhecimento do genoma tornar-se-á possivel determinar as variaçōes genéticas entre as aves e conhecer as linhagens que transmitem mais o vírus da gripe e aquelas que são mais susceptíveis a ele, e possivelmente qual a parte do genoma é responsável por este fato. Se nas pesquisas forem encontradas linhagens de maior risco, poder-se-á recomendar a nāo criação desses animais. Finalmente, o genoma desse animal servirá como um modelo para 9.600 espécies de aves conhecidas com o DNA não seqüenciado. 



\section{3 \\ Genômica Funcional}

A genômica funcional descarta o enfoque reducionista - estudar individualmente os genes e seus produtos - e focaliza holisticamente a compreensão biológica da expressão genética, pela definição compreensiva e estudos simultâneos de todos os genes nos estados fisiológicos e patológicos. A análise global da função do gene melhorou nossa habilidade de descobrir novos genes envolvidos em funções biológicas específicas, mesmo que dados não mensuráveis estejam presentes na investigaçāo. A genômica funcional procura refinar a compreensāo complexa das patologias ao definir novos alvos terapêticos e marcadores moleculares para diagnósticos, e é fundamental porque envolve métodos que facilitam a compreensão da multiplicidade das funções dos genes no complexo sistema biológico.

\section{Balé das Moléculas}

Semanalmente a imprensa divulga descobertas de novos medicamentos para o tratamento de doenças humanas, como câncer, moléstias nervosas ou degenerativas, e até mesmo infecções resistentes a antibióticos. Inúmeros avanços na área médica foram divulgados após os dados do genoma humano estarem disponiveis. Um dia, são descobertos os genes da asma ou do câncer de pele. No outro, vem à tona a ameaça dos alimentos transgênicos ou dos clones humanos. Faz parte dos protocolos científicos em todos os continentes saber onde os genes estão, o que fazem e quais os modos de controlá-los ou alterar sua atividade.

O ser humano já está aprendendo a modificar seus genes e outros aspectos de seu sistema biológico. Ou seja, está modificando a si próprio. Até recentemente, as pesquisas de moléculas potencialmente aptas a servirem como fármacos no futuro ainda eram realizadas nos laboratórios de maneira clássica. Uma vez que a estrutura de um novo princípio ativo era identificada - o que 
geralmente ocorria pelo estudo da química das plantas -, os químicos determinavam sua rota de síntese, produziam análogos estruturais, estudavam como a substância atuava em animais de laboratórios e, numa segunda etapa, verificavam sua atividade èm nível molecular.

Nesse processo clássico de triagem de substâncias para o desenvolvimento de um medicamento novo, a cada 10 mil compostos analisados 100 mostravamse promissores, 10 chegavam a ser testados em seres humanos e um 1 era eventualmente colocado no mercado como medicamento.

Tudo mudou! A genômica funcional tem sido um sucesso para a identificação de novos alvos terapêuticos. A possibilidade de identificação de mais dez mil antigenos-alvo, no genoma humano, abre oportunidades inéditas para a descoberta de novos fármacos e moléculas terapêuticas. Adicionalmente a genômica funcional possibilita também demarcar geneticamente os pacientes e estimar suas respostas a determinados medicamentos. Isto permite redução nos custos dos tratamentos, aumenta sua segurança e eficácia e reduz a toxicidade da droga.

O desenvolvimento da química combinatória, o aperfeiçoamento de bancos de dados com dezenas de milhares de estruturas quimicas e os testes moleculares realizados em laboratórios totalmente 'robotizados' e computadorizados têm acelerado a descoberta de novos fármacos. Nesses laboratórios, milhares de compostos poderão ser analisados em poucos meses, com modelos de detecção em receptores protéicos envolvidos em doenças específicas, sem a utilização de animais. Com esta tecnologia, um químico poderá desenvolver 100 compostos novos por ano, a um custo reduzidíssimo.

Espera-se muito mais inovação tecnológica na área dos medicamentos. Recentemente, foram desenvolvidos métodos que geram, em tempo real, um verdadeiro videoclipe sobre efeitos de uma droga. Por exemplo, foram filmadas moléculas enzimáticas em pleno processo de catálise. A resolução desta tecnologia é enorme. Nos clipes animados os cientistas foram capazes de observar os movimentos de átomos individuais nas moléculas atuantes. O próximo passo será capturar, em imagens, passo a passo, a ação de uma droga - reação que na maioria das vezes ocorre em uma fraçāo do segundo - ligando-se a um receptor responsável por uma patologia. Esta tecnologia congela, literalmente, o processo do medicamento em cada fase de sua ação. A parte mais difícil nesta etapa é correlacionar o tempo correto para observar cada fase da atividade do fármaco.

Pelo desenvolvimento da seqüência animada do efeito do medicamento sobre moléculas específicas, os pesquisadores acreditam que estão detectando uma 
intricada dança da vida, em nível molecular. Este método representa mais que o desenvolvimento de uma técnica sensivel para flagrar o bailado dos átomos, ele transforma o paradigma da formulação de um medicamento. Com esta técnica, identificam-se, com precisão, quais regiōes da molécula são ativas e, para melhoria do efeito da droga, quais os radicais moleculares poderāo ser alterados. Ou seja, utilizando-se este método, pode-se desenhar novas drogas para agir em locais específicos ou em configurações críticas, aperfeiçoando a eficiência de um fármaco. Esta tecnologia, aliada à química combinatória e a laboratórios 'robotizados', poderá desenvolver substâncias que inibirão etapas cruciais do balé das moléculas, diminuindo os indesejáveis efeitos colaterais que, em alguns casos, podem ser debilitantes e fatais, quase sempre anulando a possibilidade de novas terapias.

Também estão sendo desenvolvidas técnicas que revelam os genes em ação. Utilizando embriões de galinha e corantes fluorescentes de diferentes cores, pesquisadores demonstraram que é possivel observar a atividade simultânea de três genes e visualizar, com mais detalhes, como os embriōes se desenvolvem. Quando dois ou três genes são ativados no tecido, ou na célula, as cores fluorescentes se combinam para formar uma nova cor. Genes marcados em vermelho e verde formam uma imagem amarela. Se os genes forem marcados com vermelho e azul formam a cor púrpura. Combinando genes marcados com azul e verde aparece a cor turquesa. Quando os três genes marcados em vermelho, verde e azul são ativados, produzem uma imagem branca. O método associa e expande três tecnologias existentes para detectar genes:

1) Hibridização in situ, uma técnica para detectar material genético (DNA e RNA) em uma única célula;

2) Imunoquímica, na qual anticorpos detectam antígenos que podem se ligar aos genes;

3) Sinal de amplificação da tiramida, na qual se amplificam corantes fluorescentes que podem ser vistos quando iluminam os genes.

A técnica do uso de corantes fluorescentes permite a combinaçāo de imagens do embriāo em duas dimensões, num computador, para desenvolver uma imagem tridimensional que pode ser manipulada para examinar, por exemplo, a relação entre o desenvolvimento dos tecidos e órgãos. Este conhecimento possibilitará investigar medicamentos que agem em nível genético com muito mais eficiência. Espera-se que nos próximos dez anos, com a simulação em computadores do movimento das moléculas, das novas variações moleculares, dos análogos 
estruturais, e a revelação dos genes em ação, um químico possa desenvolver milhares de novos fármacos que podem agir em pontos específicos do metabolismo ou diretamente nos genes.

\section{Prognóstico e Diagnóstico Molecular}

A medicina teria caminhado além das maravilhas observadas se os avanços biológicos dramáticos, que ocorreram nas últimas duas décadas, tivessem atendido as esperanças originais criadas nas cabeças dos cientistas. As doenças poderiam ser curadas pela inserção de novos genes ou células modificadas nos pacientes. Por exemplo, a seqüência dos genes poderia ser utilizada para desenvolver novas drogas. Entretanto, a medicina baseada em genes é, sem dúvida, um alvo no horizonte, mas a distância para alcançá-lo ainda é grande. A indústria acredita que é difícil desenvolver novas drogas antes da compreensão total dos processos biológicos envolvidos na doença. Mas a medicina é complexa e, infelizmente, compreendemos somente uma pequena parte da biologia humana.

Nesta área, a ciência caminha lentamente. Sete anos após o nascimento da ovelha Dolly, e um ano após a sua morte, ainda não existe uma tecnologia consistente e confiável para clonar animais, com garantia de serem saudáveis. Mesmo na investigação das células-tronco, os estudos estão complicados. Injetar tais células nos seres humanos pode ser perigoso. Mesmo se no laboratório o experimento funcionasse não se sabe se seria uma boa idéia usar as célulastronco para tornar um produto viável.

Mas mesmo com estes questionamentos, continua o desenvolvimento de novas drogas. Senão vejamos: a indústria farmacêutica tem procurado uma estratégia inovadora para produzir novos kits para detecção de doenças e novas drogas. O primeiro ponto importante foi a conclusão de que, para entender uma doença, é necessário conhecer genética e biologia molecular. Ou seja, fazer uma correlação entre as patologias e os genes envolvidos. Uma nova aplicação da técnica de microarranjos, onde milhares de genes são colocados numa simples lâmina, está sendo desenvolvida para comparar os perfis genéticos de diferentes tecidos ou órgãos e revelar quais genes estão ativos ou são responsáveis por uma determinada doença.

A herança genética é randômica porque é impossivel prever, precisamente, quais genes, entre os $50 \%$ de origem materna e os $50 \%$ de origem paterna, são provenientes do pai ou da mãe. Por causa disto, é extremamente raro, mas 
teoricamente possivel, que irmāos não tenham coincidências e similaridades genéticas. Uma das heranças paternas transmitidas geneticamente aos filhos é a diabetes. Esta doença é grave e pode levar a ataques cardiacos, derrames e deficiências de circulação, podendo ainda causar alteraçōes da visão, provocando a cegueira. São também comuns, nas diabetes, complicaçōes renais e nervosas.

Os cientistas têm estudado inúmeras seqüências genômicas para investigar os elementos que controlam a atividade do genoma. Entretanto, devido a estas constituírem somente um pouco mais que uma lista estática de substâncias químicas, como se fosse uma lista de peças para construção de um aviāo 747, a atenção tem sido voltada para a questão de como os organismos vivos controlam a atividade genética. A chave para esta compreensāo, ou seja, de como o genoma é controlado são os reguladores genéticos, também conhecidos como fatores de transcrição.

Estas pequenas moléculas se ligam intermitentemente em regiões do DNA, próximas a um gene em particular, e então ativam a função gênica. Elas também podem influenciar a quantidade de proteínas que o gene produzirá via RNAm. O problema é que somente poucos dessies reguladores têm sido identificados nos organismos, pois são difíceis de serem localizados. Os genes reguladores se ajustam a um pequeno pedaço da fita de DNA, fazem sua função, e então desaparecem. Devido ao tamanho do genoma, a localização de um gene regulador com as técnicas convencionais de laboratório é praticamente impossivel.

Um novo método de varredura do genoma humano para detectar a relação doença e genética identificou mutaçōes associadas com a diabetes tipo 2. Esta técnica analisa a relaçāo entre os genes e a doença, focalizando os genes reguladores e os fatores de transcrição. Estes são proteínas que se ligam em áreas especificas do genoma e coordenam as ações de certos genes. Para descobrir como um fator de transcrição específico contribui para uma certa doença, é necessário localizar no genoma cada região onde o fator atua, identificar os genes deste segmento do DNA e entender como mutações nestes genes, ou defeitos neste processo, podem causar a doença.

Foram detectados vários fatores de transcrição localizados em tecidos pancreáticos e hepáticos, órgãos associados a diabetes do tipo 2. Este estudo mostrou que um fator de transcriçāo, chamado HNF4, controla cerca de 50\% dos genes necessários para o desenvolvimento do fígado e do pâncreas. Isto sugere que, sem este fator, os órgãos não funcionam normalmente. $O$ fator HNF4 possui várias mutaçōes que predispõem uma pessoa a diabetes do tipo 2 . 
Uma pequena mudança na função do fator HNF4 pode afetar a saúde do pâncreas. Assim, em poucos anos, poderá ser possivel desenvolver medicamentos que previnam a diabetes em individuos de risco e realizar diagnóstico e prognóstico para saber a probabilidade de uma pessoa vir a ter esta doença.

Compreender como os processos biológicos são regulados é um enfoque recente para investigar as doenças. Por exemplo, a compreensão do mecanismo de controle genético da divisão celular é importante para a pesquisa de doenças como o câncer, onde as células se dividem de modo descontrolado. Ao mesmo tempo, oferece novas possibilidades e estratégias para terapia.

Quando a célula está funcionando normalmente, ela reconhece os sinais químicos que induzem os processos metabólicos. Ao interpretá-los corretamente e traduzir códigos (instruçōes genéticas) contidos em seu DNA, centenas de proteinas são produzidas, as quais levam o organismo a funcionar normalmente. Em algumas doenças, a célula perde a capacidade ou torna não específica a habilidade de reconhecer estes sinais, o que leva a uma instrução genética aberrante e à produção descontrolada de proteínas.

Os cientistas desenvolveram o menor computador jamais imaginado, feito de DNA, que pode ser utilizado, automaticamente, no diagnóstico e tratamento doenças. Este aparelho, que está sendo testado em laboratório, é tão pequeno que um trilhão deles caberia em uma gota de água, podendo ainda demorar décadas para vir a ser usado na prática. Mas nos faz prever um futuro onde as tecnologias operam dentro do organismo, detectando e tratando de doenças, mesmo antes de elas apresentarem sintomas. Este computador, uma solução de DNA e enzimas, está programado para detectar RNAs que poderiam estar presentes em genes particulares, associados a doenças, se estiverem ativos. Por exemplo, o computador detecta que dois determinados genes estavam ativos $e$ dois outros inativos, e, assim, faz o diagnóstico de câncer de próstata.

Os testes genéticos podem determinar a susceptibilidade de um indivíduo para câncer, doença cardíaca, diabetes, mal de Alzheimer e fibrose cística, entre outras doenças. A esta lista, quase que diariamente, outras patologias sāo acrescidas. Mas esta promessa está temperada pelo risco de que a herança genética seja usada contra o próprio indivíduo. As pessoas compreendem que os testes genéticos podem identificar predisposiçōes para uma variedade de doenças. Algumas acreditam demais no poder preventivo desta tecnologia. De fato, somente uns poucos testes podem prever se um indivíduo desenvolverá ou não determinada doença. No entanto, ainda há um sério debate ético sobre o uso desta tecnologia e a legitimação da informação genética em vários países. 


\section{O Sensor Biológico}

O ataque cardíaco, também conhecido como infarto do miocárdio, normalmente ocorre quando é reduzido ou severamente bloqueado o suprimento de sangue que irriga o coração e as células do músculo cardíaco não conseguem oxigênio suficiente para suas demandas metabólicas. Estas células morrem se não são supridas com oxigênio. Um novo tipo de terapia gênica, que responde especificamente ao músculo cardíaco com baixo teor de oxigênio, pode proteger contra lesōes decorrentes de um infarto.

Esta terapia está baseada em um sensor biológico que ativa os genes protetores quando os sinais de deficiência de oxigênio sugerem um ataque cardíaco. Estes genes são desativados quando o fluxo sanguíneo restabelecer niveis adequados de oxigênio no coração. Em camundongos com ataques cardíacos, este sensor, regulado pelo teor tecidual de oxigênio, protege contra lesões as células do miocárdio.

Nestes experimentos, a terapia gênica, para limitar as lesões iniciais e prevenir novos problemas no órgão, foi realizada após o primeiro ataque cardíaco. Este novo conceito de terapia pode ser um tratamento alternativo à utilização de cents ou cirurgias de pontes de safena. Não é raro que o individuo que sofre um ataque cardíaco tenha outro ataque subseqüente.

Freqüentemente, a diminuição do fluxo sanguíneo do músculo do coração, conhecida como isquemia, não causa dor ou outro sintoma marcante. Esta isquemia silenciosa ou assintomática pode levar a um segundo ou terceiro ataque cardíaco sem sintomatologia. Efeitos repetidos da isquemia no miocárdio provocam lesōes cumulativas no coração que podem culminar em um ataque cardíaco fatal. Desse modo, o que o paciente necessita é uma terapia gênica estratégica capaz de agir nas células cardíacas, ativando ou desativando genes específicos. Ou seja, as proteínas terapêuticas serão produzidas somente quando e onde forem necessárias.

Um dos aspectos mais importantes deste enfoque está na habilidade de vincular diretamente genes potencialmente terapêuticos a um estímulo patológico associado a uma isquemia no miócárdio. Esta linha de pesquisa deságua em um modo de desenvolver terapias inteligentes para o coração, levando o tratamento precoce e rápido a uma variedade enorme de doenças cardíacas.

A terapia gênica é uma técnica que envolve a inserção de genes em um vetor, normalmente um plasmídio, para corrigir genes anormais ou defeituosos. Os pesquisadores desenvolveram uma molécula, batizada como vetor vigilante, que é um detector sensivel dos niveis de oxigênio e pode aumentar ou diminuir 
a expressão de genes da oxigenase heme-protetora 1 (HO-1). Este plasmídio foi inoculado diretamente nos músculos cardíacos de camundongos, uma hora após os animais sofrerem ataques cardiacos. Dez dias após, os camundongos que receberam os sensores biológicos que regulavam a terapia gênica apresentaram menos lesōes nas células cardíacas e melhores recuperaçōes da função bombeadora do coração quando comparados a camundongos injetados com salina. Os genes protetores $\mathrm{HO} 1$ agiram evitando mortes das células da musculatura cardíaca e limitando a área tecidual da lesão.

Recentemente, um 'nanobiosensor' foi desenvolvido para estudar o ambiente intracelular. Este dispositivo é uma sonda de fibra ótica de 40 nanômetros de diâmetro, suficientemente fino para ser inserido no interior de uma célula. $O$ aparelho é imobilizado em uma molécula biorreceptora, como um anticorpo, DNA, RNA ou enzima, que pode aderir na molécula-alvo, no interior da célula.

$\mathrm{O}$ biosensor pode ter inúmeras aplicaçōes. A habilidade de trabalhar em células vivas abre novas oportunidades de investigaçāo básica para entendimento de processos celulares, por exemplo, como compostos tóxicos e microorganismos patogênicos modificam o sistema biológico celular. Também pode auxiliar no desenvolvimento de novos medicamentos com mais segurança, proteção e compreensão de sua ação no interior da célula.

\section{Vacinologia Moderna: os próximos passos}

Após o dia 12 de fevereiro de 2001, quando o mundo tomou conhecimento que a seqüência do genoma humano tinha sido desvendada, uma revoluçāo silenciosa começou a ocorrer no campo da genética. Esta nova maneira de olhar os genes refletiu mudanças hercúleas na área médica. Vários aspectos da clínica médica e dos serviços de saúde serão modificados com o desenvolvimento da biotecnologia baseada na genômica e na proteômica.

A prática da saúde pública será beneficiada pelo desenvolvimento de diagnósticos mais precisos para um número mais variado de enfermidades, bem como pelos novos fármacos para controle de doenças. Detectaram-se mais de 30 mil genes e sabe-se que $0,1 \%$ da seqüência do genoma humano responde pelas diferenças entre os indivíduos. Estas diferenças poderāo determinar se uma pessoa está predisposta a uma doença específica e o que poderá ser feito para preveni-la, ou até mesmo prever reações secundárias quando for usado um medicamento específico. 
Este conhecimento levará a mais do que uma revolução na área médica, pois também terá conseqüências na economia, na política, nas técnicas reprodutivas, nas novas drogas, nos medicamentos imunobiológicos e na qualidade e expectativa de vida do cidadāo. É muito provável que novos medicamentos desenvolvidos com base na genômica e proteômica sejam utilizados para o tratamento de doenças hoje tidas como de difícil terapia. Hoje, as empresas biotecnológicas produzem cerca de 140 medicamentos e vacinas. Com o uso da tecnologia da genômica outros 350 produtos destas indústrias estarão chegando ao mercado ainda neste ano.

Dentre as tecnologias atuais para produçāo de vacinas, destacamos a vacina viva viral (e bacteriana) atenuada, que mimetiza a infeç̧ão natural e induz repostas humoral e celular, e a vacina de vírus (e bactéria) inativado, que revolucionou o controle de doenças infecciosas no século $\mathrm{XX}$ e, certamente, será uma tecnologia importante neste novo século. Vacinas baseadas em proteínas, peptídeos, polissacarídeos e até vacinas de DNA estāo sendo desenvolvidas.

As prováveis novas vacinas imunizarão contra citomegavirus, Aids, doenças meningocócicas, Alzheimer, abuso de drogas, HPV, peste, certos tipos de câncer, Escherichia coli, doença de Lime, hepatites, Clamidia, Helicobacter, tuberculose, febre amarela, dengue, malária, resfriado comum, influenza, entre outras doenças. Novas formas de aplicação de medicamentos estão sendo testadas. Em breve, ao usar sabonetes, pastas de dente, cosméticos, aerossóis e alimentos, uma pessoa poderá estar tomando sua dose diária de medicamentos ou de vacinas. Em breve, será descartada a necessidade de refrigeração para preservar vacinas.

Numa projeçāo mais ousada, a terapia do futuro poderá reconstruir lesōes, tecidos doentes, deficiências fisiológicas, estimulando o organismo a reconstruir a si próprio. Plantas serão transformadas geneticamente para expressar principios ativos específicos. Por exemplo, vegetais transgênicos já produzem vacinas contra tétano, difteria, hepatite B e cólera. Ovelhas já produzem leite com anticorpos e proteinas humanas que combatem doenças, principalmente associadas a deficiências na coagulação sangüínea. Insetos transgênicos poderão tornar-se vacinadores naturais, verdadeiras seringas voadoras, pois em suas salivas estarão presentes antígenos contra inúmeras doenças.

Um dos próximos passos será o domínio tecnológico que dará um novo enfoque para a área dos imunobiológicos - a vacinologia reversa. Utilizando o conhecimento disponível, estão sendo desvendadas seqüências de genes de microorganismos patogênicos para desenvolverem moléculas que são candidatas 
potenciais a novas vacinas. Um belo exemplo da utilização desta tecnologia está no rápido seqüenciamento do genoma do vírus causador da síndrome respiratória aguda (Sars) e na velocidade que esta informação genômica forneceu moléculas para desenvolvimento da vacina contra esta doença.

O desenvolvimento convencional das vacinas leva em conta que os microorganismos são cultivados no laboratório, para obtenção de proteínas ou outras moléculas que estimulem o sistema imunológico a produzir anticorpos. É um trabalho longo e demorado, mesmo sem ainda levar em conta que alguns agentes patogênicos não se desenvolvem em culturas. Para acelerar este processo, os pesquisadores já estão se preparando para o domínio da genômica-reversa. Mas, o que vem a ser esta tecnologia? Sabe-se que as vacinas apresentam, ao sistema imunológico do individuo, moléculas que informam que o organismo precisa se defender contra a invasão real de um agente infeccioso.

Recentemente, foram divulgados os estudos de genomas de 150 bactérias e 1.600 vírus que estão sendo seqüenciados e disponibilizados para a comunidade científica. Nos bancos de dados desses genomas pode-se encontrar genes de proteínas interessantes, que são expressas na superfície destes microorganismos. Estes genes podem ser inseridos em bactérias, por exemplo, na Escherichia coli. Estas bactérias transgênicas, além de suas proteínas, produzirão as moléculas baseadas nas instruções genéticas dos genes inseridos. Após serem isoladas, as proteínas escolhidas poderão ser testadas em animais. Esta é a vacinologiareversa, que pode realizar em poucos meses testes que, pela metodologia convencional, poderiam demorar mais de 30 anos.

Um outro belo exemplo é o da vacina contra a varíola. Recentemente, os pesquisadores produziram a vacina usando apenas quatro genes do vírus vaccinia (responsável pela varíola bovina), o mesmo vírus usado na produçāo da vacina licenciada contra a variola humana. Normalmente, esta vacina contém o vírus amortecido, o que leva a um potencial enorme de indução de sérios efeitos colaterais, às vezes levando a mortes.

Esta vacina é suspeita de causar inflamação cardíaca e, no passado, podia causar a morte de duas a cada 1 milhão de pessoas vacinadas. Indivíduos com imunodeficiência estão sempre em risco quando vacinados contra varíola. No entanto, a vacina de DNA não causou efeitos adversos. Como os vírus são muito parecidos geneticamente, é possivel encontrar uns poucos genes que protegerão os seres humanos, bem como os animais, contra estes três tipos de viroses: varíola humana, bovina e de macaco. 
Nesta investigação, os primatas foram divididos em quatro grupos, o primeiro contendo macacos inoculados com a vacina antivariola clássica. Um outro grupo, com macacos injetados com a vacina de DNA contra a varíola, contendo apenas um único gene, chamado L1R. Um terceiro continha macacos inoculados com uma vacina de DNA contra o Hanta vírus. E um último, o grupo-teste, consistindo de macacos tratados com a vacina produzida com quatro genes. A técnica da vacina de DNA envolve imunização com plasmídios, o que codifica um ou mais genes do vírus. Quando o plasmídio é introduzido em uma célula, o gene clonado é expresso e as proteínas codificadas são apresentadas ao sistema imune que inicia a produção de anticorpos protetores contra o vírus.

O resultado deste experimento demonstrou que, após uma injeção letal do vírus da variola de macacos, os animais vacinados com a vacina clássica não apresentaram sinais clínicos da doença e, conseqüentemente, não morreram. Entretanto, os primatas vacinados contra Hanta vírus morreram 7 a 14 dias após o desafio, como conseqüência da inoculação do vírus.

Os animais que foram inoculados com a vacina de DNA L1R tornaram-se portadores da doença, mas recuperaram-se, sugerindo que este gene conferiu alguma proteçāo. Os Rhesus imunizados com a vacina de DNA 4-genes não foram somente protegidos contra a letalidade do virus, mas também não apresentaram a doença em sua forma mais severa.

Nos últimos 25 anos, a variola foi erradicada como uma doença natural humana. Assim, as licenças de futuras moléculas que se candidatam a vacinas são obtidas somente quando se utilizam os primatas não-humanos para testes. Entretanto, com a ameaça do bioterrorismo, a produção da vacina molecular é fundamental para dar segurança à humanidade. $\mathrm{Na}$ vacinologia reversa, os pesquisadores utilizam supercomputadores (algoritmos bioinformáticos) para responder a questões específicas envolvendo a comparação de vários genomas $\mathrm{e}$ proteomas de agentes infecciosos e suas possiveis respostas imunes.

Numa visão de futuro, com estes supercomputadores, gastaríamos somente algumas poucas horas para resolver problemas genômicos e proteômicos complexos, que necessitariam de anos de estudos em laboratórios caríssimos, planejados para ter uma segurança biológica impecável contra agentes patogênicos e outros micróbios perigosos.

Estudando genomas e proteomas de patogênicos múltiplos, observando as similaridades ou 'homologias' entre as proteínas expressas na superficie de várias espécies de microorganismos e o tempo evolucionário, pode-se escolher ou 
prever com maior segurança quais são os genes e as proteínas candidatas prováveis à vacina. Com este conhecimento será possível desenvolver um vacina totalmente sintética.

\section{A evolução das metodologias para produção de novas vacinas}

A área do desenvolvimento tecnológico na produção de metodologias para criaçāo de novas vacinas evolui de uma forma muito rápida, senão vejamos:

1. Pesquisadores australianos divulgaram, em outubro de 2004 , nos Proceedings of the National Academy of Sciences, a criação de uma vacina sintética efetiva contra vírus, bactérias patogênicas e tumores, e que pode gerar um novo arsenal de vacinas para os seres humanos e animais. A vacina sintética oferece uma série de vantagens se comparada às vacinas tradicionais. Por exemplo, enquanto a vacina tradicional contém pequenas quantidades de vírus vivo ou atenuado, a vacina sintética não possui nenhum material infeccioso. A vacina sintética pode ser produzida em larga-escala de maneira econômica e não apresentar efeito colateral. Ou seja, ela é planejada para tipos de alvos específicos da reação imunológica. Assim ela pode, de um lado, ativar a produção de anticorpos; de outro, estimular a resposta imune celular. As primeiras tentativas de desenvolver vacinas baseadas em peptídeos sintéticos fracassaram devido à fraca resposta de produção de anticorpos. Agora, para resolver este problema, os pesquisadores adicionaram uma estrutura lipídica para aumentar a capacidade para indução de anticorpos. Assim, a nova vacina sintética se baseia em uma simples estrutura composta de dois epitopos: a) pequenas seqüências de peptídeos que são reconhecidas pelo sistema imunológico; b) uma estrutura lipídica que age como identificadora de alvo - uma particular célula no organismo - para a vacina. A adição do lipídio amplifica enormemente o resultado da resposta imune.

2) Pesquisadores também estão trabalhando em desenvolvimento de novas tecnologias para vacinas e imunoterapia para câncer. Até o início dos anos 80 , a tendência da tecnologia das vacinas era a purificação do princípio ativo. Por exemplo, a vacina contra hepatite $B$ não era produzida utilizando-se parte do vírus, e sim uma única proteína da superfície do vírus da hepatite $B$. Agora, a nova maneira de pensar é que, para inúmeras doenças, é necessária uma resposta imunológica complexa envolvendo elementos do sistema imune como as células $T$, células $B$, que produzem anticorpos, e citoquinas, que são moléculas que induzem as células $\mathrm{T}$ e $\mathrm{B}$ a realizarem seus trabalhos. É como uma orquestra 
sinfônica executando um clássico. Para isto não são necessários somente violinos e piano, há que se ter outros instrumentos de sopro e percussão. No desenvolvimento de uma vacina contra câncer, por exemplo, não se utiliza somente o gene que seja o antígeno do tumor, mas também se usa um gene que codifica uma citoquina. Com isto, aumentará a resposta imunológica desejada. Este é um fato novo porque até agora ninguém desenvolveu uma vacina baseada somente na resposta celular. Explicando melhor, vamos imaginar doenças que possuem vacinas como o sarampo e a variola. Estas vacinas estão baseadas na produçāo de anticorpos que atacam o virus diretamente. As vacinas que produzem uma resposta celular nāo destroem o agente patogênico; elas agem destruindo as células infectadas pelos microorganismos. Estas poderāo ser células infectadas por um vírus, como o do HIV ou uma célula cancerígena, que de alguma maneira são reconhecidas pelo sistema imune celular. Por exemplo, quando um vírus contamina uma célula, interfere no sistema de sintese de proteínas, fazendo que esta célula produza também proteínas virais. Partes dessas proteínas podem aparecer do lado externo da célula, levando as células $\mathrm{T}$ a reconhecê-las e identificando-as como proteínas estranhas. Assim, as células $T$ destroem as células que expressam estas proteinas. Esta nova tecnologia poderá colocar em uma mesma vacina a resposta de destruição celular e a resposta com produção de anticorpos. Este tem sido o foco mais pragmático desta nova tecnologia para produção de agentes vacinais.

3) A diabete é um tipo de doença grave aparentemente resultante de uma predisposiçāo genética causada por fatores ambientais desconhecidos que levam a uma resposta auto-imune. Esta doença se manifesta de duas maneiras: a diabete do tipo 1, que ocorre geralmente em pessoas com menos de 40 anos quando as células pancreáticas, chamadas de células beta, produtoras de insulina, são destruídas; e a diabete do tipo 2, que geralmente ocorre em pessoas mais idosas quando o organismo não responde normalmente ao hormônio ou não produz a insulina em quantidade suficiente para controlar os níveis de glicose no sangue. Os cientistas britânicos estão investigando o uso de células-tronco, transplante de órgãos, regeneração celular e também drogas novas e vacinas para terapia, procurando restabelecer a habilidade de o organismo produzir insulina. O único tratamento desta doença nos últimos 80 anos ainda é a injeção diária de insulina. A Bristol University e o King's College de Londres estão desenvolvendo uma vacina contra esta doença. Esta vacina já está sendo testada, desde agosto de 2004, em 18 pacientes com o tipo da diabete 1 . O início dos testes nos seres humanos marcou um dos mais importantes avanços na luta 
contra a doença desde a prescrição de insulina recomendada a partir de 1920. Este novo tratamento pode agir como uma vacina e uma cura. Pessoas que possuem familiares com risco de diabete podem ser vacinadas para prevenir aparecimento da doença, e aquelas que foram diagnosticadas recentemente como diabéticas podem bloquear o seu progresso, pois, em média, o organismo demora cinco anos para cessar a produção de insulina. No entanto, infelizmente, os pacientes portadores da doença não se beneficiarão desta vacina em curto prazo. Os pesquisadores ingleses iniciaram o estudo em seres humanos, após o sucesso do tratamento de camundongos, que foram inoculados com uma proteína, isolada do sangue de camundongo e que é uma molécula idêntica a uma parte das células beta produtoras de insulina. Esta estrutura adicionada ao sangue impedia o organismo de destruir estas células. Os animais diabéticos foram protegidos da doença pelo resto de suas vidas. Estudando amostras de sangue humano, os cientistas identificaram uma proteína que apresentava uma seqüência equivalente à observada em camundongos. A vacina desenvolvida contém um peptídeo com seqüência semelhante, e que, quando adicionada ao sangue, protege as células produtoras de insulina contra a ação agressiva do organismo. Este tipo de tratamento foi um sucesso em camundongos e espera-se agora o mesmo nos testes com os seres humanos. 


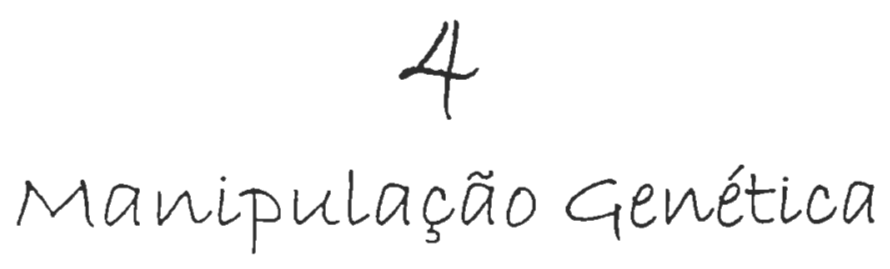

A manipulação genética consiste em experiência cientifica na qual células são fundidas, genomas são manipulados pela recolocaçāo de genes existentes ou modificados, há adição de genes extras e produção de clones, células-tronco e animais transgênicos, ou para fins de terapia gênica, mostrando que a natureza biológica pode ser alterada para produzir organismos melhorados, órgāos para transplantes e curas para certas patologias.

\section{A Fusão cenética}

Para alguns, a ciência deveria estar ligada somente ao que às pessoas consideram como aspectos positivos para a humanidade. Tal relação ideológica geralmente se alinha ao que é bom para a humanidade com o que não é progresso. Muitas vezes, porém, esse raciocínio não corresponde à realidade, mesmo quando novas tecnologias são desenvolvidas e utilizadas sem a necessária compreensão e discussão com toda a sociedade. Um dos casos que deverá tornar-se um item de pauta na imprensa, em futuro próximo, é a fusão de células animais. A capacidade de duas células se fundirem em uma é essencial para a geração de um feto (fusão do esperma com o óvulo) e para o desenvolvimento de tecidos como os ossos, músculos e placenta.

Apesar da enorme importância biológica do processo da fusāo, pouco se conhece das proteínas e genes envolvidos neste processo. Foi identificado o gene o eff-1, no verme $C$. elegans, que não é somente essencial, mas também suficiente para as células se fusionarem. Pesquisadores expressaram este gene artificialmente em células que não se fusionam naturalmente, e estas adquiriram a habilidade de se fundirem entre si. Aparentemente, o gene eff- 1 é essencial para a fusão de células, desde o primeiro orifício entre as membranas celulares até sua completa fusão. 
Assim, alguns experimentos desenvolvidos revelaram as condiçōes para a fusão de células vivas e biologicamente ativas, através da utilização de células com membranas modificadas por engenharia genética. A fusāo celular significa que duas células en traram em contato e suas proteínas se fundiram na superfície de uma das células, que reconheceu um receptor na outra célula. $O$ ato de reconhecimento leva à fusão das membranas lipídicas. Este processo, conhecido como biofusão, pode levar ao desenvolvimento de novas terapias, de vacinas c a reparos de tecidos lesados.

Recentemente, foram desenvolvidos embriōes de porcos inoculados com células-tronco humanas, que produziram células híbridas com materiais genéticos de ambas as espécies. Os dados, totalmente inesperados, mostraram que células humanas e suínas fusionadas tinham marcadores semelhantes de superfície celular. E mais: surpreendentemente, a análise molecular do sangue e dos órgãos dos suínos adultos que, quando fetos, tinham recebido células humanas, demonstrou a presença de células com material genético de porcos, de humanos e também células híbridas.

No entanto, observou-se que nessa fusão foi carreado um retrovírus suíno (Perv), primo distante do HIV (o vírus que causa a Aids), apto a infectar células humanas normais. O mais interessante é que um dado prévio mostrava que o vírus suíno não infectava células humanas. Embora não exista uma explicação plausível para a questão de saber como esta fusão se processa, e se a infecção viral pode ser útil, por exemplo, para o estudo da Aids, esse resultado aponta, pela primeira vez, para uma maneira de fundir células entre espécies diferentes, e mostra uma infecção viral que passa diretamente de células animais para células humanas.

Os dados da fusāo de células puderam explicar como um retrovírus pode infectar células de espécies diferentes, facilitando a compreensāo das zoonoses. Esse tipo de fusão celular é do maior interesse para aqueles que estudam saúde pública, doenças infecciosas, imunologia e transplantes. Alguns vírus, como o da influenza (gripe), são bem conhecidos por passarem de uma espécie animal para outra. Algumas viroses podem se difundir entre diferentes espécies animais, o que de fato ocorre, embora raramente, e em circunstâncias especiais.

A ciência quer saber como e por que certas viroses podem passar para diferentes espécies animais, pois certas zoonoses são doenças devastadoras. Exemplos terriveis são os do vírus HIV, que causa a Aids humana e que pode ter surgido entre macacos selvagens, passando para a espécie humana em poucas 
décadas; do coronavirus, responsável pela Sars, que passou para o homem através de gatos selvagens asiáticos; e do vírus da gripe dos frangos, que já matou diversos vietnamitas.

Essa pesquisa é importante para entender a biologia dos transplantes. Pelo mundo afora, inclusive no Brasil, milhares de pessoas necessitam de transplantes de órgãos como fígado, coração, pulmão, rins e pâncreas. Muitas dessas pessoas morrem por nāo ter, no momento necessário, órgãos disponiveis. O xenotransplante - uso de órgāos de animais no homem - é uma das tecnologias que pode ser explorada para salvar a vida do ser humano necessitado. Se a fusāo genética vier a permitir o desenvolvimento de órgāos animais com baixa rejeiçāo pelo sistema imune humano, por que não usá-los nos transplantes de órgãos? A nossa sociedade precisa começar a discutir o uso desta tecnologia.

\section{A ciência das Células-Tronco}

As células-tronco sāo encontradas em embriōes humanos, fetos, cordōes umbilicais, placentas e alguns outros tecidos. Recentemente, pesquisadores induziram a diferenciação celular para produzir novamente células-tronco. Embora tal re-diferenciação ocorra em processos naturais, jamais tinha sido realizada em laboratório. Os cientistas esperam algum dia cultivar célulastronco em laboratório para utilizá-las no tratamento de doenças. A pesquisa sobre as células-tronco, no fundo, é uma 'batata quente', devido ao potencial terapêutico e ao dilema ético associado às técnicas necessárias para produção dessas células.

Para diminuir o problema ético, os pesquisadores têm usado células-tronco obtidas de cordões umbilicais e de placentas. No entanto, elas mostraram-se menos versáteis que as células-tronco embrionárias. Além disso, também foi demonstrado que células da medula óssea e células adiposas, obtidas por lipoaspiração, têm o potencial de serem reprogramadas, ou seja, de se comportarem como células-tronco.

Certas células envolvidas no desenvolvimento de ovos da 'mosca da fruta' puderam ser estimuladas a se transformarem em células-tronco. Estas células são precursoras dos ovos, podendo apontar para novas fontes de células-tronco em outros tecidos animais, inclusive os dos humanos. Por outro lado, pesquisadores coreanos criaram as primeiras células-tronco humanas obtidas a partir de embriōes clonados, com uma aistura de métodos: a técnica padrão e uma outra nāo convencional. Basicamente, foram utilizados óvulos humanos 
desnucleados, nos quais foi inserido DNA de outras células, conseguindo-se que os ovos se desenvolvessem até os primeiros estágios de divisão embrionária. Após esta fase, os embriōes foram destruídos para remoção das células-tronco. Foi demonstrado que estas células eram geneticamente semelhantes às da pessoa que forneceu o DNA.

As células-tronco são classificadas em três grupos:

- Totipotentes - capazes de tornarem-se quaisquer tipos de células;

- Pluripotentes - geram quaisquer tipos de células com exceção daquelas necessárias ao desenvolvimento do feto, como a placenta;

- Multipotentes - transformam-se em um número limitado de células.

Enquanto o óvulo fertilizado é considerado totipotente, as células isoladas do interior de um embriāo de um dia são pluripotentes e as células-tronco obtidas de adultos são multipotentes. Estas últimas são conhecidas como célulastronco adultas - o termo adulto se refere à maturidade das células e não à idade do indivíduo. Todos os seres humanos têm como origem um óvulo fertilizado - uma célula-tronco totipotente. Esta célula se divide em duas, que formam quatro, quatro fazem oito, 16,32-60 trilhōes de células. Neste desenvolvimento, as cèlulas, seguindo suas instruçōes genéticas, estimulam certos genes $e$ inibem a ação de outros. Se alguma coisa na natureza pode ser considerada mágica são estas células, pois são versáteis e podem tornar-se células especializadas e serem transplantadas no doador que deseje substituir um tecido lesado ou doente, sem ameaças de rejeiçāo.

O uso médico de células-tronco não é novo nem foi motivo de controversa na área médica. Como já vimos, após a célula-tronco se diferenciar em um tecido embrionário ela se torna célula 'somática' ao invés de se chamar célula totipotente. Como o embrião desenvolve em feto, as células-tronco continuam a se especializar em células multipotentes, que possuem funções específicas e limitado potencial de produzir tecidos. Por exemplo, células-tronco multipotentes da pele podem produzir quaisquer tipos de células de pele, mas nāo podem se transformar em células sanguíneas ou cerebrais. Elas têm sido usadas para tratar doenças sanguíneas e condiçôes de auto-imunidade, bem como para produzir ossos e cartilagens, por mais de 20 anos. O primeiro tratamento de lúpus sistêmico com transplantes de células-tronco foi realizado há sete anos e apresentou $70 \%$ de sucesso. Células-tronco hematopoiéticas (hemato significa sangue; poiético significa criar) são somente multipotentes. 
No entanto, vários cientistas acreditam que mesmo as células-tronco embrionárias não sāo panacéias para todas as doenças. Para eles, a idéia de que as células-tronco totipotentes possam curar doenças ou lesōes teciduais ainda nāo tem fundamento científico. As células-tronco são encontradas no organismo humano desde o desenvolvimento do feto até o individuo falecer e têm a função de durante a vida refazer as células que, por vários motivos, são destruídas pelo organismo. Os pesquisadores acreditam que as células-tronco estão disponíveis para todos os tipos de tecidos e refazem quaisquer ferimentos, se necessário. Espera-se que no futuro estas células possam ser utilizadas em transplantes para tratamento de lesões nervosas e cardíacas ou de diabetes.

Mesmo com estes questionamentos, pesquisadores sul-coreanos utilizaram 242 óvulos humanos frescos, obtidos de 16 voluntárias que os doaram especificamente para este estudo. Este pode ser um dos pontos importantes para o sucesso da técnica, pois normalmente os óvulos sāo obtidos em clínicas de fertilidade, desconhecendo-se sua idade e apresentando, potencialmente, menor qualidade biológica. Também foi utilizada uma nova técnica para remover - DNA dos óvulos. Ao invés do DNA ser sugado por uma pipeta finíssima, foi feita uma pequena abertura na membrana dos óvulos que, delicadamente espremidos, permitiam a saida dos núcleos.

De fato, a sucção do núcleo utilizando pipeta pode causar microlesões no tecido próximo ao núcleo, deixando os cromossomos defeituosos, quando são chamados de aneuplóides. Aparentemente, a remoção do DNA, realizada pelos coreanos, retira menos material celular das vizinhanças do núcleo. Uma outra inovação foi que o núcleo reposto em cada óvulo era da mesma pessoa que doou o óvulo. $\mathrm{Na}$ clonagem de animais, foram usados DNA de individuos diferentes, para facilitar a comprovação de que o embrião clonado possuía o mesmo DNA do doador.

É possível que a utilização do óvulo e do DNA de uma mesma pessoa tenha sido uma vantagem para o sucesso dessa clonagem. Quando o núcleo é inserido no óvulo desnucleado, ele carreia material da célula de onde foi retirado. No caso dos coreanos, isto pode ter levado a uma menor incompatibilidade, pelo fato de o núcleo doado ser da mesma pessoa. Uma vez inserido o DNA, esperou-se duas horas para que ele fosse reprogramado, ativando genes embrionários versáteis, aptos a coordenar o desenvolvimento fetal. Os sinais que regulam o desenvolvimento das células-tronco e o controle da obtenção de um determinado tipo específico de célula são os segredos para utilização das células-tronco na regeneração ou reparação de tecidos lesados. 
Recentemente foi demonstrado que células-tronco mesenquimais, que naturalmente se transformam em células gordurosas, cartilagens, ossos e músculos, quando forçadas a assumirem forma esférica, transformam-se, eficientemente, em células precursoras das células gordurosas, enquanto aquelas esticadas tornam-se células ósseas. Os cientistas também investigaram os compostos químicos nos quais as células se desenvolvem. Após cultura de cinco ou seis dias, o embrião atinge o estágio de blastócito. Neste ponto, a massa celular é de aproximadamente 100 células, compondo uma forma arredondada, com 75 células do lado externo e 25 células na parte interna. Com esta técnica foram cultivados 30 blastócitos para se obter 20 massas de células-tronco. Entretanto, foi obtida somente uma simples linhagem de células-tronco. Os resultados são promissores, mas o transplante baseado em células-tronco ainda é uma esperança distante e deve-se ter cuidado antes de afirmar que este é um avanço espetacular. A verdade é que ninguém ainda sabe se as célulastronco terão poderes curativos.

Apesar de ter sido divulgado que as células-tronco poderiam reparar danos causados por lesões parasitárias ou funcionais no tecido cardíaco, teses contrárias têm sido demonstradas, como as que se referem às células-tronco não se transformarem em miócitos cardíacos após a injeção em um miocárdio lesado. Outros pesquisadores estão otimistas e acreditam que as células-tronco poderão ser usadas no tratamento de infarto do miocárdio. Estudos prévios demonstraram o potencial das células-tronco de reativar a musculatura cardíaca e desenvolver vasos sangüíneos. O tratamento não causou nenhum efeito colateral sério. Os batimentos cardíacos eram anormais e os coraçōes bombearam mais sangue, se comparados a órgãos que somente sofreram cirurgias.

Nos próximos cinco anos, os especialistas estimam que seja desenvolvida a tecnologia dos tecidos engenheirados, possivelmente cultivando órgãos humanos flácidos em formato tridimensional, sem contaminação de ossos, cartilagens e outros tecidos. Assim, órgãos complexos, como fígado e pâncreas, poderão ser desenvolvidos. Isto poderá levar a um tremendo impacto no que se refere ao transplante desses órgãos para tratamento de hepatite e diabetes. Em uma década será possivel desenvolver ou regenerar órgãos, como o coração, diversos músculos, estômago etc., causando impacto na vida de milhões de pessoas. O ganhador do Prêmio Nobel Walter Gilbert acredita que nos próximos 20 anos cada um dos órgãos humanos será desenvolvido em laboratório. Assim que um órgão se tornar doente, envelhecido ou lesado, haverá a opção produzir um novo órgão com o uso de células-tronco. 
Pesquisadores demonstraram recentemente, procurando superar questōes éticas e legais levantadas pelo uso de células-tronco de tecido fetal, que célulastronco da medula de indivíduos adultos, chamadas estromas, cultivadas na presença de fatores de crescimento, transformaram-se em células-tronco que foram convertidas em células cerebrais e responderam a critérios utilizados para transplantes em cérebros lesados. Estudos estāo sendo desenvolvidos através de experimentos, em animais com desordens neuro-degenerativas, para explorar o potencial regenerativo dessas células convertidas.

Células-tronco obtidas de tecidos adultos oferecem um grande potencial terapêu tico. Mas, permanece o desafio de tratar uma doença com estas células, por causa de sua incapacidade de se desenvolverem num laboratório. É prioritário definir o mecanismo molecular do crescimento e o processo de replicação ou ciclo destas células. Há pouco tempo foi descrito que células-tronco sangüíneas de camundongos, com deficiência do gene p18, tinham a capacidade de se multiplicarem e desenvolverem com facilidade. Este gene é da classe dos chamados 'inibidores da quinase dependente de ciclinas', que são inibidores críticos na regulaçāo do ciclo celular. Assim, o isolamento de células-tronco deficientes de p18, ou a retirada deste gene, é uma estratégia nova para proliferálas e torná-las mais eficazes no combate às doenças.

Mesmo com estes possíveis avanços, a questão da clonagem terapêtica levanta questōes políticas e éticas. Um ponto se refere à pressão para as mulheres não doarem óvulos para a clonagem. Um outro questionamento diz que o uso de células-tronco embrionárias reduz a vida humana a pouco mais que um produto farmacêutico. Ainda temos a questão sobre quando a vida começa. Responder a isto, pelo menos até agora, está além da ciência. No momento da fecundação, o ovo tem o potencial de gerar um bebê. Se isto significa vida humana não está claro cientificamente. Entretanto, já existe um consenso mundial no meio científico de que a clonagem humana para reprodução seria altamente perigosa e equivocada. Toda clonagem reprodutiva deveria ser evitada.

Temos de iniciar o engajamento de pessoas da comunidade científica e não científica para nos ajudar nas questōes éticas e sociais relacionadas a este assunto. Parece-me claro que criar o novo ser humano por clonagem nāo tem uma justificativa plausível numa sociedade civilizada. No entanto, a geração de célulastronco por meio da técnica da transferência nuclear envolvendo as mesmas pessoas interessadas pode tornar-se um avanço extraordinário nos transplantes e terapias, vindo a socorrer indivíduos afetados por terriveis lesōes e doenças. 
Em toda a ciência biológica, nos últimos anos, houve um avanço extraordinário na utilizaçāo de ferramentas moleculares. Nos campos da medicina e agricultura foi dada uma ênfase particular, no início da década de 1970, à tecnologia de transferência de genes. $O$ desenvolvimento desta técnica sugeria novas possibilidades para o uso da engenharia genética em várias áreas de biologia pura e aplicada. No campo da aplicaçāo, foram considerados alvos as doenças que prejudicavam a produçāo agrícola e a saúde pública. Nestas duas áreas do conhecimento, apesar dos esforços dos entomologistas, químicos e ecologistas em desenvolver novos métodos para efetivo controle, os insetos representavam o maior problema para a sociedade moderna, como pragas agrícolas ou vetores de doenças para o homem e os animais.

A mosca Drosophila melanogaster foi transformada geneticamente, na década de 1980, estimulando novas idéias relacionadas ao uso da transgênese para controle de insetos. Entretanto, a aplicação desta tecnologia em outros insetos somente foi possivel quando quatro transposons (pedaços de DNA que carreiam os genes a serem inseridos) foram construídos: mariner, Minos, Hermes e piggy-Bac. Estes elementos transposonais têm sido usados para transformar 15 espécies de insetos, incluindo dípteros, himenópteros, lepidópteros e coleópteros. Como ferramentas de laboratório, os elementos transposomais provaram ser a tecnologia-chave para mediar a transformação nestes animais. Estes vetores podem ser úteis para modificação genética em uma enorme variedade de espécies de insetos.

Utilizando-se deste conhecimento, a biotecnologia está desenvolvendo insetos geneticamente modificados para uma variedade de propósitos, incluindo os relacionados à agricultura e saúde pública. A liberação dos insetos transgênicos em larga escala na natureza ainda deve demorar alguns anos. Se realmente tiverem uma repercussão positiva, os insetos modificados podem ser importantes para a economia e a saúde pública. Por exemplo, os Anopheles transgênicos seriam incapazes de transmitir malária, doença que ataca de 300 a 500 milhões de pessoas por ano, e que causa de um a três milhões de óbitos. Os Aedes aegypti não transmitiriam o vírus da dengue que infecta, anualmente, milhares de pessoas além de causar um grande impacto na economia. Em insetos confinados em laboratórios, a utilização de mosquitos geneticamente alterados, refratários ao plasmodium, parasita da malária, é um modelo espetacular e elegante do uso da transgênese em insetos. 
Já foram identificados três genes do mosquito que podem afetar o ciclo de vida do plasmódio no Anopheles gambiae. Dois desses genes, CTL4 e CTLMA2, codificam proteínas que protegem o desenvolvimento dos parasitos. Quando estes genes são silenciados, o sistema imune do mosquito destrói mais de $97 \%$ dos parasitos. Um terceiro gene, LRIM1, tem o efeito oposto: mosquitos que têm este gene retirado produzem mais parasitas do que os insetos normais. Estas descobertas trouxeram novas possibilidades para controlar a malária. Por exemplo, mosquitos transgênicos com genes extras que destroem os parasitas, ou deleção dos genes que protegem o plasmódio, podem ser extremamente úteis na diminuição da propagação da doença.

Também está sendo estudado um aspecto molecular relacionado a um mecanismo hormonal da excreção do Aedes aegypti, o vetor da dengue e da febre amarela. Como o mosquito produz a resposta diurética após o repasto sangüíneo? Os mosquitos se alimentam e, rapidamente, iniciam a excreção ou produção de urina. Estāo sendo clonados genes e estudados receptores celulares de mosquitos. Os receptores são proteínas de membranas celulares envolvidas na transferência de informação de uma regiāo da célula para outra. Este processo de comunicação celular é regulado por hormônios. A interferência neste processo refletirá na diminuição da diurese, levando o inseto à morte.

Outros exemplos de transgênese: as abelhas geneticamente modificadas tornaram-se resistentes a doenças e parasitas que devastaram inúmeras populaçōes desses insetos. O bicho da seda 'engenheirado' produziu proteínas, como a seda mais resistente para produzir vestimentas especiais, pára-quedas e ligamentos artificiais. Entretanto, ainda não se sabe que efeitos estes insetos terão sobre $o$ ecossistema, a saúde pública e a segurança dos alimentos, se liberados na natureza. O sucesso dos insetos transgênicos está na habilidade de destruir os insetos selvagens e de estabelecer uma população sem prejuizo ao meio ambiente.

Os receios dos pesquisadores na liberação dos insetos transgênicos é que esta liberação aumente a possibilidade de um gene modificado se espalhar através da população de insetos e piore os problemas pré-existentes ou crie novos desafios biológicos. Também é possivel que o inseto modificado liberado no campo cause uma consequiência não imaginada, por exemplo, tornando a população de insetos mais eficiente na propagação de uma epidemia ou, até mesmo, tornando-se vetor de uma doença que antes não era transmitida pelo inseto. Há a possibilidade que a modificação genética da abelha, por exemplo, possa alterar a composição do mel produzido, criando problemas quanto à segurança do alimento. 
A engenharia genética aplicada aos insetos, infelizmente, ainda não possui normas regulatórias bem definidas, que focalizem a segurança ambiental e outras exigências associadas aos insetos geneticamente modificados. São necessárias uma articulação e uma condução transparente de como os insetos transgênicos serão controlados, quais os ministérios envolvidos, quais os riscos, benefícios e incertezas científicas relacionadas a este tipo de tecnologia molecular. Não nos parece que um simples ministério possua a autoridade para cobrir todos os aspectos levantados para liberação de diferentes tipos de insetos modificados. Pelo menos os ministérios da Saúde, da Agricultura e do Meio Ambiente deverão estar envolvidos nesta regulamentaçāo.

\section{A Terapia Gênica}

A terapia gênica envolve a inserção de genes selecionados em um paciente, com a esperança de melhorar ou curar uma doença. Inicialmente, foi vista como uma solução para o tratamento de doenças genéticas. Atualmente, esta terapia está sendo avaliada para outros tipos de doenças, incluindo câncer, doença vascular, artrite e desordens neuro-degenerativas. Muito embora as estratégias para o uso da terapia gênica sejam muito variadas, certos elementos são indispensáveis para o sucesso desta tecnologia. Como ponto inicial é básico que um gene importante tenha de ser identificado e depois clonado.

$\mathrm{Na}$ terapia genética o gene 'ruim' pode ser corrigido pela inserção, através um vetor, geralmente um virus, do gene 'bom'. Após a identificação e clonagem do gene, o próximo passo é a sua expressão. Problemas quanto à eficiência da transferência gênica e sua expressão permanecem como tópicos importantes no desenvolvimento da terapia gênica. Uma das dificuldades desta tecnologia se relaciona com a transferência do gene desejado para as células-alvo, além da obtenção de um nível de expressão suficiente para o tratamento da doença. Normalmente, um vírus é utilizado para carrear o gene e infectar o organismo. O vírus multiplica-se rapidamente injetando o gene 'bom' nas células do paciente.

São necessárias mais investigações sobre a transferência de gene e a especificidade do tecido na sua expressão. Um outro ponto importante na estratégia da terapia gênica é a compreensão da genética da doença considerada, inclusive dos efeitos colaterais potenciais da terapia gênica, e o conhecimento sobre as células-alvo que receberão a terapia gênica. Os avanços recentes da biologia molecular facilitaram a identificação, isolamento, determinação da seqüência, 
clonagem e expressão de inúmeros genes e seus produtos. As ferramentas usadas para isto, como 'northern, western e soutbern blots', e a reaçāo da cadeia da polimerase (PCR) levaram a uma avaliação mais precisa das atividades de genes individuais na reposta celular. A facilidade de introduzir genes em várias células in vitro e a fidelidade da replicaçāo do material genético nestas células tornaram a terapia gênica uma tecnologia importante para várias atividades médicas.

Nos próximos dez anos, os especialistas acreditam que cinco a dez doenças genéticas poderão ser tratadas por esta terapia. Nos próximos 20 anos, calculase que 50 a 100 doenças genéticas poderão utilizar a terapia genética. No entanto, o tratamento ficará restrito a doenças dependentes de um simples gene, devido à enorme dificuldade de estudar doenças causadas por uma combinação de genes, e à interação com o ambiente. Nos próximos 30 anos, é provável que centenas de doenças sejam tratadas por esta terapia. Doenças multigênicas vão demorar décadas para serem tratadas pela terapia gênica. Estas doenças incluem problemas mentais que afligem $1 \%$ da humanidade (em geral esquizofrenia), doenças auto-imunes (artrites, lúpus) e doenças cardíacas.

\section{A imunodeficiência severa combinada e a terapia gênica}

Cientistas ingleses publicaram na revista The Lancet, de dezembro de 2004, novas informações sobre a tecnologia de terapia gênica que normaliza o sistema imunológico de crianças com imunodeficiência severa combinada (SCID). Esta doença interfere no sistema imune, em particular no sistema de leucócitos ativos, levando à patologia descrita há alguns anos, como a de David Vetter, paciente que viveu por 12 anos na 'bolha' para se prevenir de infecçōes. Neste estudo, quatro crianças com SCID tiveram as células-tronco removidas da medula, e os genes foram identificados e colocados em um vírus da leucemia. Este vírus foi então introduzido de volta nos pacientes nos quais os genes foram replicados. Após este tratamento gênico o sistema imune dos pacientes funcionou normalmente.

\section{A clonagem para Terapia}

Um dos assuntos científicos mais apaixonantes, neste início de século, referese ao debate mundial sobre a realização ou não da clonagem humana. Vários países acabaram de optar pela proibição do uso desta tecnologia, inclusive da 
clonagem terapêutica, terapia que os cientistas acreditam ser a chave para tratamento de várias doenças degenerativas, como mal de Parkinson, Alzheimer, diabetes e lesōes no tecido nervoso. Baseados no lobby dos contras e do movimento contra o aborto, o principal argumento utilizado pelos proibicionistas foi que a clonagem humana é baseada na destruição de embriões de quatro dias de idade, processo classificado por eles como um assassinato. Argumento oposto a este, com base nas centenas de embriōes descartados pelas clínicas de fertilização in vitro, diz que seu uso poderia levar ao tratamento de pessoas necessitadas.

Diariamente vemos na imprensa notícias e argumentos utilizados para tornar ilegal a clonagem humana para obtenção de células-tronco. Geralmente sāo reflexōes que mexem mais com o imaginário e o emocional das pessoas do que com sua lógica e raciocínio, nāo levando em consideração que a clonagem tem enormes perspectivas benéficas para a sociedade. Ouvimos que a clonagem pode ameaçar a dignidade do clone, ou que os cientistas estāo brincando de Deus e tentando criar um futuro desumanizado gerando castas como em uma colméia em que o genoma de inúmeros individuos será único e padronizado.

Estes argumentos nos deixam a impressão de que a clonagem terapêutica humana será condenada por todos ou considerada um crime contra a humanidade. Os cientistas estão profundamente divididos sobre esse assunto, mas mesmo os mais conservadores não são claros sobre o descarte dos embriōes ou sua utilizaçāo em pesquisas. A questão básica é: quando um ser humano se torna um ser humano? Os especialistas em ética argumentam, e com razão, que o problema não está em quando a vida começa, mas na utilizaçāo dos embriōes que são descartados pelas clínicas de reprodução assistida. Também garantem que, na era da globalização, leis nacionais obviamente não são sufıcientes para controlar este tipo de atitude.

A tecnologia da clonagem realmente pode responder a algumas questões básicas da biologia. Enquanto a maioria dos cientistas se opōe à clonagem humana, que leva ao nascimento de uma criança, conhecida como clonagem reprodutiva, vários pesquisadores apóiam a clonagem terapêutica. Nesta mesma linha, cerca de 40 cientistas, laureados com o Prêmio Nobel, se manifestaram.

Sabemos que inúmeros avanços científicos relevantes, hoje vistos com a maior naturalidade, foram condenados levando em conta os valores morais e religiosos enraizados em nossa sociedade. Como bom exemplo, temos o caso de Galileu, que há 400 anos, em Florença, descobriu que a Terra não era o centro do universo. Ou de Charles Darwin, cuja teoria da evolução mexeu com os que acreditavam que Deus tinha criado direta e pessoalmente todas as criaturas. 
Ainda podemos citar as repercussões negativas que tiveram a anestesia, as vacinas, os transplantes de órgãos, a fertilização in vitro e mais recentemente dos animais e plantas transgênicos, entre outros - técnicas utilizadas normalmente no mundo de hoje. O que podemos concluir desses fatos é que o ser humano possui reaçōes imediatas que são emocionais e morais e não que dizem respeito ao bom senso e à lógica, ou a uma visão promissora e esperançosa quanto ao futuro. Quantas pessoas morreriam ou sofreriam hoje sem vacinas e anestesias?

Em 1869, o Papa Pio IX declarou que a vida começa na concepção. Entretanto, em 1978, a embriologia humana mudou para sempre. Louise Brown, o primeiro bebê nascido de fertilização in vitro (test tube baby), provou que era possível manter um embrião humano no laboratório - pelo menos por 14 dias; depois, o embrião deve ser implantado no útero de uma mulher, ou congelado. A fertilização in vitro criou problemas para os eticistas. O que é realmente aglomerado de células em uma placa de laboratório? O debate permanece não resolvido. Se quisermos testar, por exemplo, um risco genético, toma-se um embriāo no estágio de desenvolvimento de cinco células e removem-se duas células para o teste. As células remanescentes ainda podem ser chamadas de embrião? Cada uma das duas células retiradas, em teoria, é capaz de desenvolver um embriāo. Elas são embriōes também?

A clonagem é também conhecida como transferência nuclear ou transferência nuclear de células somáticas, um processo que pode produzir uma cópia genética de uma outra pessoa, sem o convencional encontro entre o óvulo e o espermatozóide. $\mathrm{Na}$ clonagem, o núcleo de um óvulo é removido e substituído pelo núcleo de uma célula somática adulta. Este núcleo contém toda a informação genética de uma pessoa particular. Após o núcleo ter sido colocado no óvulo, a célula é submetida a uma carga elétrica, e o novo núcleo passa a coordenar o desenvolvimento de um novo ser humano, cuja composição genética de DNA nuclear é uma cópia idêntica da célula somática original. O embriāo também pode ser formado por partenogênese - um modo de o ovo não fertilizado formar um indivíduo. Alguns peixes, pássaros e cobras se reproduzem naturalmente através da partenogênese. No entanto, ainda não se sabe o potencial deste método na produçāo de células-tronco humanas.

A clonagem tem sido realizada também numa grande variedade de animais: Dolly, a ovelha, foi um dos mais famosos clones. Recentemente, em um estudo detalhado, foi comparada a clonagem por transferência nuclear de células somáticas com a inseminação por injeção intracitoplasmática de espermatozóide e a partenogênese em óvulos de camundongo. Os embriōes desenvolvidos por 
partenogênese e por injeção intraplasmática de esperma apresentaram similares desenvolvimentos até o estágio de blastócito, e não revelaram quaisquer sinais de anormalidades, enquanto os clones atingiram somente $30 \%$ deste desenvolvimento, alguns com sinais de anormalidades.

O maior interesse da clonagem não é a formaçāo de um novo indivíduo. A clonagem reprodutiva humana é considerada uma técnica de riscos e enfrenta enormes dilemas éticos. No entanto, se os embriōes pudessem se desenvolver para formar estruturas multicelulares conhecidas como blastócitos, eles poderiam ser fontes de células-tronco embrionárias, aquelas que são capazes de se dividir repetidamente, e, quando estimuladas com sinais biológicos corretos, podem se transformar em diferentes tipos de células. Alguns afirmam que já conseguiram clonar embriōes humanos até 16 células, entidade chamada de mórula predecessor de um blastócito. Outros dizem que já geraram células-tronco, através da partenogênese, e estão trabalhando para construir um banco de célulastronco com características particulares do sistema imune, a fim de diminuir o risco de rejeição, quando for o caso.

Os primatas (incluindo o ser humano) são mais difíceis de serem clonados do que outros animais, devido à maquinaria molecular necessária para a divisão celular ser, de algum modo, alterada durante o processo da clonagem. Um modo de evitar esta agressão é a partenogênese, que já foi feita em macacos. Estas células se desenvolveram e se dividiram em diferentes tipos, incluindo células nervosas que produziam dopamina, uma substância que se torna deficiente no mal de Parkinson. O próximo passo será inoculá-las em macacos para verificar se tais células se comportam de maneira similar a células cultivadas. Outro problema é tentar cultivar células-tronco humanas em tubos de ensaio. Infelizmente, nesta condiçāo, essas células nāo crescem bem e em quantidades e purezas suficientes para trabalhos de pesquisa, ou para aplicações terapêuticas.

Foi divulgado pela impressa mundial que cientistas sul-coreanos deram um enorme salto em direção à clonagem de um embrião humano para obtenção de células-tronco - células que podem substituir tecidos de indivíduos que estão doentes ou com algum tecido lesado. Os cientistas desenvolveram a técnica com base na 'compressão' delicada de ovócitos para retirada do núcleo, ao invés da técnica tradicional com agulha e vácuo, e utilizaram 242 óvulos humanos para realizar a clonagem. A idéia era produzir embriōes clonados de células saudáveis de pacientes e retirar do embriāo as células-tronco que poderiam ser usadas para reparar o órgão ou o tecido lesado. Estas células, provenientes de pacientes geneticamente idênticos, não seriam, em teoria, rejeitadas pelo sistema 
imune dos receptores. Dos 242 óvulos doados, 176 tiveram o núcleo retirado, e destes somente 30 embriōes foram gerados, cada qual contendo de 100 a 150 células-tronco. Entretanto, apesar disso, foi produzida somente uma linhagem de células que puderam ser cultivadas no laboratório. Em dezembro de 2005, os trabalhos do sul-coreano Woo-Suk Hwang sobre clonagem humana foram considerados fraudes, e a revista Science cancelou as publicaçōes dos artigos. Todavia, com esta técnica será possivel, no futuro, que um coração com parte do tecido necrosado tenha este tecido substituído por um novo músculo cardíaco; ou que células-beta das ilhotas pancreáticas não funcionais sejam substituídas por células normais, produtoras de insulina; ou ainda que células nervosas ativas sejam usadas para tratamento do mal de Parkinson. Mas ainda há um longo caminho pela frente até chegar ao processo terapêutico. No entanto, mesmo com essa longa estrada a ser percorrida, a promessa é real, embora, até agora, os cientistas tenham produzido somente células-tronco, que ainda devem ser transformadas em células específicas de tecido cardíaco, pancreático ou nervoso.

Antes de considerar a possibilidade de inocular células-tronco em pacientes, uma série de questōes necessitam ser respondidas: as células-tronco serão realmente incorporadas somente no tecido lesado? As células-tronco poderão se transformar em tipos de células nāo necessárias ao tecido lesado? As célulastronco se multiplicarão, incontrolavelmente, e poderão produzir câncer? Apesar desses questionamentos, a descoberta dos cientistas coreanos é um avanço para a biologia. A clonagem terapêutica deixou de ser um sonho.

As primeiras células-tronco embrionárias foram isoladas em 1994, por Ariff Bongso, professor de obstetrícia e ginecologia da Universidade Nacional de Singapura. Desde esta época sabe-se que, para torná-las úteis à terapia, teriam de ser transformadas em células específicas de tecidos a fim de serem inoculadas nos pacientes. Para evitar complicaçōes colaterais, como formação de teratomas, a população de células transformadas deve estar sem contaminação de outras células.

Ian Wilmut, o cientista que clonou a ovelha Dolly, quer investigar uma doença neuromotora que afeta os neurônios motores do cérebro e espinha dorsal. Estes neurônios são células nervosas que recebem as instruçōes cerebrais e as transmitem em forma de impulsos elétricos para os músculos. A degeneração desses neurônios torna os músculos flácidos e enfraquecidos. Wilmut quer encontrar os erros existentes nas células nervosas de pessoas que sofrem desta doença. Ele pretende retirar DNA do sangue, ou de um outro tecido, de uma pessoa que tenha a doença neuromotora, e implantar num óvulo humano que 
tenha tido o núcleo removido. O ovo é estimulado a produzir células-tronco e não bebês. Enquanto o embrião ainda estiver nos primeiros estágios de desenvolvimento, algumas células serão retiradas para estudos. Estas células poderão ser usadas para criar vários tipos de células nervosas, que são afetadas na doença neuromotora. $\mathrm{O}$ embriāo depois será destruído. $\mathrm{O}$ sucesso de seu trabalho pode ter profunda implicação em várias doenças nervosas e genéticas. A identificação dos genes envolvidos nesta doença seria mais fácil. É bem verdade que o conhecimento da seqüência dos genes é o primeiro passo para resolver a terapia contra determinadas doenças. No entanto, ainda faltaria saber como as influências ambientais determinariam se o indivíduo portador destes genes teria ou não a doença.

O próprio Wilmut vai tentar criar um animal clonado perfeito nos próximos cinco - dez anos. Wilmut admitiu que se a clonagem de mamíferos é agora uma realidade, o processo de clonagem ainda é um problema não bem resolvido. Ele acredita que pode desligar o 'relógio biológico' na célula clonada, evitando os problemas do envelhecimento prematuro que afligiu a Dolly. Este 'relógio' parece estar embebido nos núcleos das células, o qual pode ligar ou desligar vários processos e sinalizar inclusive a morte celular. Isto significa na clonagem que, quando um núcleo é transferido para um ovócito, elementos da célula agem como se fossem da mesma idade do organismo doador. Isto não é problema se o núcleo for obtido de uma célula jovem, mas se ele for adquirido de uma célula adulta pode causar inúmeros problemas. No caso da Dolly, cujo material genético foi obtido da glândula mamária de animal adulto, o efeito 'relógio' estava relacionado com a artrite e o câncer de pulmão que a levou à morte com somente seis anos, sendo que a vida média de uma ovelha é por volta de 10 a 16 anos. O que Wilmut deseja é compreender como os vários processos biológicos são controlados no núcleo e como 'convencê-los' de que são novamente de um organismo jovem.

Todavia, não se pode repetir aqui os erros que ocorreram com a difusão da biotecnologia vegetal. A maneira como esta tecnologia foi divulgada ao grande público foi arrogante. O receio da sociedade deve ser levado em conta. As questões levantadas sobre a moralidade de usar embriões existentes, ou que serão criados, com o propósito de pesquisa e utilização para tratamento médico, devem ser consideradas profundamente. Homens e mulheres têm seus limites sociais.

No caso da clonagem humana terapêutica, nós temos três alternativas de engajamento. Na primeira, podemos lutar contra o desenvolvimento científico e somar nossas forças às conservadoras que procuram deturpar toda nova 
tecnologia que poderá mudar o futuro do planeta. Na segunda, podemos ainda ficar sentados e passivamente ver o panorama do futuro que está vindo. Alternativamente, podemos participar da criação de um futuro melhor no qual o ser humano usará os avanços científicos e tecnológicos para evitar, prevenir ou tratar de doenças e do processo de envelhecimento, para aumentar sua expectativa e melhorar a qualidade de vida e, conseqüentemente, aumentar o bem-estar no planeta.

De qualquer maneira, a sociedade brasileira deve iniciar o debate e agir com discernimento em questōes como 'quando a vida humana começa?' e tentar legalizar a clonagem terapêutica e as pesquisas com células-tronco. Finalmente, é preciso colocar na balança o fato de a ciência tentar socorrer as pessoas que necessitam de tratamento para doenças que hoje não têm cura contra a possível eliminaçāo neste processo de terapia de células de um embrião de quatro dias.

\section{A clonagem de primatas não-humanos}

Gerald Schatten e colegas da Universidade de Pittsburgh, Pensilvânia, Estado Unidos, divulgaram na revista Developmental Biology, em 11 de dezembro de 2004, o resultado da pesquisa sobre a clonagem de um ovo de um primata nãohumano até o estágio de blastócitos. Nesta fase, o fluído interno do ovo contém camadas de células-tronco embrionárias. Utilizando a técnica de 'comprimir' delicadamente do ovócito para remoção do núcleo - método descrito pelos sul-coreanos para criar a primeira linhagem de células-tronco de um clone humano -, os cientistas deram um enorme avanço em direçāo ao sucesso da clonagem terapêtica em embriōes de primatas não-humanos. Este conhecimento facilitará a compreensảo das células-tronco humanas embrionárias e responderá inúmeras questões sobre como as células-tronco embrionárias funcionam e se elas podem ou não ser usadas efetivamente e com segurança no tratamento de doenças e lesões.

Apesar de este estudo representar um significativo progresso, várias barreiras para clonagem de primatas não-humanos ainda permanecem. Schatten e seus colegas descreveram na revista Science, de abril de 2003, que, apesar de a técnica de transferência nuclear ter sido sucesso na clonagem da Dolly, camundongos e outros animais, em macacos não funcionava. Neste estudo, os pesquisadores encontraram obstáculos moleculares básicos que bloqueavam o desenvolvimento celular, como a ausência ou deficiência de proteínas importantes, estruturas mitóticas caóticas e cromossomos desalinhados. 
Para melhorar o processo de clonagem, no artigo recente, o grupo americano retirou o núcleo de um ovócito, 'comprimindo' delicadamente a célula, ao invés de remoção do material genético utilizando-se uma agulha e vácuo. Os pesquisadores também utilizaram, na transferência nuclear, ovócitos que não estavam completamente maduros, ainda no primeiro estágio da meiose, quando o número de cromossomos começa a reduzir pela metade, para formar o ovócito pronto para a fertilização pelo espermatozóide. $\mathrm{Na}$ técnica tradicional, os ovócitos tinham os núcleos retirados no segundo estágio (metáfase) antes de ocorrer a mitose.

Apesar do sucesso, a clonagem reprodutiva nestes animais permanece distante. O grupo americano mostrou no artigo, claramente, a dificuldade de obter primatas clonados (e talvez humanos): 135 embriōes clonados de macacos foram implantados em 25 fêmeas Rhesus e nenhuma gravidez obteve sucesso.

\section{Xenotransplantes}

A lista de espera para transplantes de órgãos continua a aumentar mais rapidamente do que o número de órgãos humanos disponíveis. Centenas de pacientes falecem à espera de órgãos. Os avanços científicos e tecnológicos têm fornecido esperanças para estes individuos, devido à possibilidade de órgãos de outras espécies animais serem transplantados nos seres humanos. Esta terapia dos sonhos, porém, ainda vai demorar a chegar, mas estão sendo dados os primeiros passos nesta direção. Este revolucionário processo de transplantes de órgãos entre diferentes espécies é conhecido como xenotransplante, e se refere a um futuro grande negócio para transplantes de órgãos vivos de uma espécie para outra.

A maior vantagem do uso de órgãos de animais para transplantes em humanos é o fato que se trata de uma maneira de ofertar órgãos de um animal saudável, ao invés de órgãos de uma pessoa já falecida, que podem ter alguma lesão tecidual resultante da morte. Mesmo órgãos obtidos de uma pessoa com morte cerebral, considerados candidatos ideais para transplantes, contêm normalmente pequenas anomalias. Sabe-se que o processo da morte cerebral causa lesões em outros órgãos, particularmente no coração. Como resultado, alguns órgãos transplantados não estāo numa condiçāo ideal.

Utilizando-se a tecnologia dos transgênicos, a idéia é produzir quimeras, parte homem, parte animal, como fábricas vivas de produção de células e órgãos para transplantes. Alguns tecidos suínos têm sido usados pelo ser humano, 
como pâncreas para produçāo de insulina e válvulas cardíacas para substituição das defeituosas humanas. Além disso, por exemplo, pode-se combinar DNA do homem com o de suínos. Como resultado desta junção de dois segmentos de DNA, o porco transgênico levará em seu genoma uma pequena amostra de genes humanos, em número insuficiente para criar uma nova espécie animal. Quanto mais geneticamente similar um animal for do homem, menos o sistema imune rejeita o órgāo animal. Quando a diferença nos genes for muito grande o órgão animal é rejeitado em nano-segundos pelo ser humano transplantado. Entretanto, o porco transgênico deverá possuir genes suficientes para que seus órgãos não sejam rejeitados quando transplantados para um ser humano. Não resta dúvida de que esta tecnologia será questionada, ética e moralmente, por várias facçōes sociais, que vêem este processo como não natural.

Além disso, há sempre o risco de o transplante de órgão animal ser uma fonte de transmissāo de viroses animais para a população humana. $O$ porco, por exemplo, coexiste muito bem com um virus conhecido com retrovírus endógeno suíno (Perv em inglês) que não pode ser eliminado do animal. Tem sido demonstrado que o Perv nāo causa doença em ratos de laboratório, embora nāo se saiba se este retrovírus pode contaminar o homem. Considerando os efeitos de viroses animais que infectam o homem, como o ébola, e possivelmente o virus da Aids, nāo pode ser descartado o risco desta contaminação.

No entanto, este animal quimera já está sendo criado e um dia produzirá células geneticamente idênticas, suficientes para reparar tecidos danificados ou mesmo órgãos para transplantes. Estas células terão um baixo índice de rejeição pelo paciente e serão conhecidas como tecidos 'humanizados'. Os xenotransplantes poderāo salvar centenas de vidas humanas e ser considerados como um método de tratamento. Esta tecnologia deverá ser implementada e melhorada, pois, se bem sucedida, será um avanço fundamental para a medicina. Uma vantagem importante seria que não estariam sendo criados embriōes humanos, como na clonagem terapêutica, que é um método mais questionável.

Alguns indagarão por que utilizar suínos como fonte de órgãos? Por várias razões. Uma delas é que estes animais existem em grande quantidade, são relativamente baratos e de fácil manuseio zootécnico. Na prática do xenotransplante sempre haverá o risco de introduzir novos agentes patogênicos, como retrovírus que poderiam sofrer uma mutação e infectar células humanas. Entretanto, os pesquisadores acreditam que poderão selecionar suínos livres de microorganismos. Uma outra vantagem é que o tamanho dos órgãos dos porcos 
é semelhante ao dos de seres humanos. Além disso, as anatomias dos coraçōes de ambas as espécies são similares, bem como as dos rins, pulmōes e fígados.

Já foram realizados experimentos de transplantes de três corações de suinos transgênicos em três macacos. Um dos animais transplantados foi capaz de sobreviver por trinta horas. Tal experimento, realizado antes do desenvolvimento da tecnologia dos transgênicos, levava os macacos a viverem somente de 30 a 90 minutos. A rejeição atrasa o uso deste processo nas práticas clínicas, mas o coraçāo de um suíno transgênico bate muito mais tempo no peito de um macaco do que um coraçāo de porco normal. Em termos genéticos, como os macacos são muito próximos aos seres humanos, acredita-se que estes dados representem como o homem reagiria a um xenotransplante.

Imagina-se que nos próximos cinco anos ocorrerão os primeiros transplantes de órgāos de animais em homens e mulheres. O maior problema do uso de órgãos de suínos nos humanos é a rejeição. Os porcos têm um açúcar - a galactose - na superfície de seus vasos sanguíneos, que é um excelente alvo para anticorpos humanos. Os anticorpos atacam o órgão transplantado, levando a uma rápida destruiçāo. Uma solução para a rejeiçāo é transformar geneticamente o animal doador, de tal modo que seus órgãos não mais expressem a galactose.

A produção de suinos transgênicos é um processo relativamente simples. As porcas são expostas a um aumento de hormônios que as conduz a um processo de superovulação. As fêmeas são acasaladas e os óvulos fertilizados. Os ovos resultantes, conhecidos como zigotos, são coletados nos ovidutos - tubos que ligam os ovários ao útero. O ovo embrionário é entāo inoculado com uma solução contendo segmentos do DNA humano. Desde que somente um pequeno segmento de DNA é inoculado no ovo, nem todos serão incorporados ao DNA do animal, ou seja, em média somente $1 \%$ deles expressará a nova informação genética. Entretanto, quando os porcos transgênicos cruzam entre eles, 50\% dos embriōes resultantes expressam $1 \%$ do segmento do DNA humano. Os suínos crescerão até a fase adulta, idade em que seus órgãos serão removidos cirurgicamente. Depois os animais serão sacrificados.

Nos experimentos iniciais foram extraídas e injetadas em fetos de ovelhas células-tronco mesenquimais humanas. Elas se tornaram partes dos coraçōes, peles, músculos, gorduras e outros tecidos das ovelhas. Mas o número de células humanas ainda era muito pequeno. Recentemente, foram obtidas, através do aprimoramento dessa tecnologia, quimeras ovelha-homem com uma proporção de $15 \%$ de células humanas no fígado do animal. As células humanas deviam 
ser inoculadas por volta da metade do período de gestação, antes de o sistema imune do feto ter aprendido a diferença entre suas próprias células e as humanas. Para assegurar que o animal ainda é uma ovelha normal, foram criados animais híbridos por fusão dos embriōes das ovelhas 'humanizadas' com carneiros.

Com a familiarizaçāo lenta e gradual desta tecnologia pela sociedade, o conceito de xenotransplante se tornará mais aceitável, principalmente considerando que estes órgãos poderão salvar a vida de um grande número de pacientes que enfrentam a lista de espera, devido à falta de doadores de órgãos humanos. Com o avanço do conhecimento científico sobre genética da hibridizaçāo e quimeras, em um futuro não muito distante, o xenotransplante se tornará uma opção real para aqueles que necessitam de um órgão por sofrerem de uma enorme variedade de doenças lesivas a seus organismos.

\section{Das Fêmeas e não dos Machos}

A natureza decidiu que para os mamíferos a reprodução sexual é a mais interessante, pois nela participam os genomas do macho e da fêmea. Por outro lado, as abelhas, formigas e alguns peixes, aves e répteis, podem reproduzir-se assexuadamente, utilizando o DNA maternal, através de um processo biológico conhecido como partenogênese. Este mecanismo jamais foi observado naturalmente nos mamíferos. Estes animais possuem uma reprodução característica, que necessita dos componentes $\mathrm{Y}$ e X para produzir um novo individuo. No ser humano, o óvulo e o espermatozóide contêm similar número de cromossomos (22 autossomos + o cromossomo sexual $X$, na fêmea; e $Y$, no macho). $\mathrm{Na}$ reprodução, a fusão do óvulo e do espermatozóide reconstitui um genoma humano completo com 46 cromossomos.

Entretanto, foi divulgado, recentemente, o nascimento de Kaguya, a filha de duas camundongas, o que demonstrou que um mamífero saudável conhecido como 'partenota', pôde ser produzido pela fusāo de dois grupos de cromossomos femininos, sem a participação do sexo masculino. A inserção de um núcleo de um óvulo geneticamente modificado em um óvulo normal foi realizada em aproximadamente 600 óvulos. Após implantes de 457 ovos nos úteros de camundongas, somente 28 embriões foram produzidos. Destes, nasceram duas camundongas. Os restantes foram abortados ou nasceram anormais. Um dos 'partenotas' se desenvolveu até a fase adulta e apresentou habilidade de reproduçāo, produzindo várias ninhadas após acasalamento com um macho. Normalmente, os mamíferos adquirem a metade dos cromossomos das fêmeas 
e a outra metade dos machos. Quando acontece dos embriões possuírem somente cromossomos femininos, normalmente morrem nas primeiras etapas do desenvolvimento placentário. Aqueles que possuem somente materiais genéticos masculinos geralmente são defeituosos.

O imprinting genômico foi a grande descoberta para o desenvolvimento desta tecnologia. Ou seja, alguns genes sāo expressos no DNA maternal, mas estão bloqueados no DNA paternal, ou vice-versa. Após bloquear o genechave no óvulo da doadora do DNA, os cientistas fusionaram dois óvulos. O gene bloqueado está envolvido no mecanismo que controla a atividade dos genes oriundos do macho e da fêmea. Os óvulos fusionados foram ativados quimicamente para produzir embriōes que foram implantados nas placentas de camundongas.

Assim como na clonagem, um outro tipo de reprodução assexuada é possível em camundongos, e talvez seja possível em alguns outros mamíferos. Entretanto, a eficiência desta tecnologia é muito baixa, menor que no processo de desenvolvimento da ovelha Dolly. Somente $0,6 \%$ dos embriōes criados sobreviveu. Assim é impensável, inaceitável e inseguro utilizá-la em seres humanos.

No experimento divulgado, os pesquisadores focaram dois genes importantes para o imprinting genômico. Os genes Igf2 e H19, que residem no cromossomo 7 do camundongo, são também expressos no embrião humano. Quando o óvulo do camundongo amadurece, o $\mathrm{H} 19$ torna-se ativo e o Igf2 é inativado. Entretanto, no espermatozóide, o oposto ocorre com os mesmos genes. No cromossomo masculino, o gene H19 está inativo e o gene Igf2 é ativo.

Normalmente, quando dois grupos de cromossomos maternais são fusionados, o embrião nāo se desenvolve porque os genes não são apropriadamente ativados. Os pesquisadores retiraram o gene $\mathrm{H} 19$ de um ovócito imaturo de camundonga e observaram que o gene Igf2 no genoma maternal tinha sua atividade aumentada. Sabe-se que o Igf2 regula a produção de uma proteína que por sua vez regula o desenvolvimento do embriāo. $O$ gene alterado teve um grande impacto sobre a expressão de mais de mil genes, demonstrando a complexidade da regulação do desenvolvimento embrionário.

Por que na evoluçāo dos mamíferos foi selecionado o processo de reprodução que envolve genes de macho e de fêmea? Uma resposta simples seria que isto maximiza a mistura de gene dos dois sexos. Sem dúvida, se somente as fêmeas fossem responsáveis pela reprodução, elas produziriam uma populaçāo de individuos geneticamente semelhantes. O mesmo é verdade para os machos. 
Plantas e animais que têm a competência de reproduzir por partenogênese ou androgênese (fusão de dois espermatozóides) produzem machos quando aumenta a necessidade deles. No entanto, este nāo foi o processo de seleção na evolução dos animais mamíferos.

De qualquer maneira, acreditamos que ainda nāo chegou o fim do sexo masculino. Dados recentes demonstraram que o macho não é obsoleto. Apesar da clonagem, que produz um embriāo sem a fertilização do óvulo pelo espermatozóide, e do nascimento de camundongos sem pai, o macho tem mais importância na procriação do que se pensava. Foi descoberto que o espermatozóide fornece, além dos cromossomos masculinos na fertilização do óvulo, cerca de três mil moléculas de RNA mensageiras que são introduzidas no óvulo pela célula reprodutiva masculina no ato da fecundação. Destas, foram identificadas seis moléculas encontradas no espermatozóide e nos ovos fecundados, mas não nos óvulos não fertilizados.

Aparentemente, estes RNAs agem nas primeiras etapas do desenvolvimento embrionário. Utilizando espermatozóides humanos para 'fertilizar' artificialmente óvulos de hamsters, foram encontradas nos óvulos duas moléculas de RNA provenientes das células masculinas. Elas carreavam instruçōes genéticas para síntese das proteínas protamina-2 e clusteína. Esta última molécula está envolvida em numerosos processos da fertilização e no desenvolvimento embrionário saudável. Talvez estes dados expliquem a baixa eficiência da clonagem, ou seja, no embrião clonado deve haver deficiência dos RNAs fornecidos pelos espermatozóides.

\section{A Misteriosa Máquina celular}

Nos últimos anos, apesar de a ciência ter avançado como nunca em toda sua história, ainda conhecemos muito pouco sobre os mecanismos moleculares que controlam o desenvolvimento, a diferenciação e a regulação da divisão celular. Há pouco tempo a união de um espermatozóide com um óvulo era a única maneira de gerar a vida nos mamíferos. Este conceito começou a mudar quando os cientistas criaram animais através da clonagem, como foi o caso de Dolly, a ovelha vedete, e de tantos outros animais.

Estas investigações são importantes porque existem cientistas que acreditam que a espécie humana poderá se extinguir em 10 milhões de anos. Isto se refere principalmente ao cromossomo $Y$ que poderá perder seus 45 genes, incluindo o gene SRY responsável pela produção de hormônios. Este cromossomo surgiu 
a 300 milhōes de anos possuindo 1.438 genes. Assim, neste periodo já perdeu 1.393 genes. Aparentemente um outro cromossomo terá a tarefa de desenvolver um gene para determinação do sexo. Os pesquisadores acreditam que se o cromossomo $Y$ for extinto isto poderia criar dois ou mais sistemas de determinação sexual resultando em duas espécies humanas diferentes. Alguns cientistas acham que o cromossomo $Y$ perdeu genes desnecessários e que não perderá os genes essenciais para a manutenção da espécie.

Sabendo do risco de extinção, pesquisadores japoneses há pouco tempo produziram um camundongo misturando DNA obtidos de duas fêmeas. O macho ficou fora da jogada! Em contrapartida, cientistas americanos sugeriram uma maneira de as fêmeas não fazerem parte desta equação reprodutiva, pois acabam de mostrar que camundongos machos foram capazes de produzir óvulos. Este novo modo de manipular a construçāo da vida pode, eventualmente, encaminhar a ciência para um lado que evitará as objeções éticas, morais e religiosas existentes em torno da pesquisa envolvendo embriões humanos. Com isto espera-se que se torne realidade a promessa médica de desenvolver célulastronco humanas sem destruir nada que seja considerado uma vida em potencial.

Os pesquisadores conseguiram produzir óvulos a partir de células-tronco embrionárias, sem utilizaçāo de fêmeas. Este experimento foi realizado em camundongos, mas a possibilidade de que dois homens pudessem combinar seus materiais genéticos para gerar um bebê existe, pelo menos teoricamente. Um homem supriria o espermatozóide e o outro o óvulo. Na realidade este não é o problema, os pesquisadores querem é entender o ainda complexo mistério da vida. Como alguma coisa tão pequena, como um ovo, pode desenvolver-se como um animal ou um ser humano completo?

Os óvulos são as células mais importantes do organismo, mesmo se comparados aos espermatozóides, por que eles colocam em sintonia o relógio biológico da reprodução. Numa clonagem, ao se transferir um DNA de uma célula adulta normal para um óvulo, o ovo formado reprograma o DNA, tornando-o totalmente diferente daquele existente no tecido do qual foi retirado. Esta célula clonada torna-se capaz de se desenvolver como qualquer tipo de células do organismo ou de tornar-se uma entidade complexa, como um organismo vivo. A clonagem fornece para a misteriosa máquina celular chamada ovo a possibilidade da volta no tempo.

Se o óvulo for fertilizado ou clonado, no ovo resultante formam-se célulastronco, desejadas pelas suas promessas médicas, já que podem se dividir e se 
tornarem diferentes tipos de tecidos, como células de pele para screm utilizadas no tratamento de queimaduras, neurônios para serem usados em pacientes com doenças neuro-degenerativas, ou células pancreáticas que podem revolucionar o tratamento da diabete, e assim por diante. No chamado clone terapêutico, o DNA de um paciente é transferido para um óvulo e produz células-tronco embrionárias que podem se diferenciar em tecidos e células que possuem o código genético do paciente: um perfeito tecido ou órgāo, à prova de rejeição. $\mathrm{Na}$ busca de tais células, cientistas coreanos anunciaram, este ano, que tinham clonados embriōes humanos, utilizando óvulos de mulheres doadoras.

A objeção a este trabalho não é somente devida ao fato de essa clonagem poder produzir uma criança, mas também devida à produçāo e destruição de aglomerados de células, em um estágio do desenvolvimento que, em teoria, poderia produzir bebês, caso fossem implantados num útero. Alguns indivíduos argumentam que embriōes, mesmo que ainda microscópicos e desestruturados, nāo importando como foram desenvolvidos, são seres humanos. Outros somente vêem, nestes casos, aglomerados de células.

Os óvulos gerados por camundongos machos, caso produzissem célulastronco, evitariam as objeções quanto a colocar as fêmeas para doarem seus óvulos. Quando os óvulos obtidos de dois machos foram identificados, tentou-se fertilizá-los com espermatozóides. Mas, infelizmente, não funcionou! Os óvulos possuem o tempo fisiológico exato para serem fecundados. A utilização destas células muito cedo ou muito tarde impossibilita a fecundação. $\mathrm{O}$ controle da natalidade baseado na tabela da ovulação tem este princípio. $O$ espermatozóide é mais versátil, ele poderá fecundar um óvulo se for inserido durante diferentes estágios de sua maturação.

Outros cientistas conseguiram produzir espermatozóides de camundongos a partir de células-tronco e usaram as células para fecundar óvulos desses animais. Os óvulos normalmente possuem somente o cromossomo $\mathrm{X}$, enquanto os espermatozóides podem ter um $\mathrm{X}$ ou um $\mathrm{Y}$, assim determinando o sexo da prole. Para sobreviver, o animal necessita pelo menos de um cromossomo $\mathrm{X}$. No entanto, os pesquisadores que produziram óvulos a partir de células-tronco acreditam que possam ter óvulos $Y$ que se desenvolveriam em machos se fertilizados com um espermatozóide $X$.

Quanto mais se desenvolvem os trabalhos engenhosos de biologia nos laboratórios, mais opçõcs éticas e legais estarão sendo buscadas. Por exemplo, o uso da clonagem para desenvolver células-tronco embrionárias é preferível 
ao pagamento de uma mulher para incubar células clonadas até o embriāo estar crescido e ser depois abortado para possibilitar seu uso como fonte de tecidos para tratamento de lesōes.

\section{Pobre dos Atletas comuns e Mortais}

Antes do atentado terrorista na Espanha e, mais recentemente, ao aproximarem-se as olimpiadas da Grécia, as autoridades encarregadas da segurança já tinham solicitado à Organização do Tratado do Atlântico Norte (Otan) ajuda para garantir a tranqüilidade e evitar acontecimentos indesejáveis durante os jugos en $\Lambda$ tcnas. $\Lambda$ gora, com maior razāo, a preocupaçao deve ter aumcntado. No cntanto, em jogos olímpicos anteriores, a maior ameaça aos atletas era a utilização de substâncias estimulantes ou excitantes ilegais conhecidas como doping - para melhorar o desempenho. A aplicação ilegal de estimulantes já era comum em cavalos de corridas para aumentar o rendimento.

Historicamente, as primeiras drogas conhecidas para tal finalidade foram o ginseng, o ópio, e esteróides obtidos de testículos de ovelhas. Nas décadas de 1940 e 1950, com o avanço do conhecimento na área da endocrinologia, apareceram os esteróides anabolizantes e algumas outras substâncias não esteróides, com efeitos semelhantes. Os esteróides anabolizantes são derivados do hormônio masculino, a testosterona, formando a androstenediona, a nandrolona e o estanozolol, entre outros compostos. Eles aumentam a massa muscular e sua contratura e a resistência à fadiga, diminuindo o ritmo cardíaco, bem como o período de recuperação - fatores críticos para os atletas em vários tipos de esportes que envolvem força de explosão muscular. Estas drogas não são específicas, e os pesquisadores estão aprendendo mais sobre fatores locais de desenvolvimento muscular.

Os avanços da biologia molecular e da engenharia genética permitiram que pacientes que possuem distrofia muscular, com perda de músculo seletivo, pudessem ser tratados com fatores genéticos locais para recuperarem sua atividade física. Por outro lado, já se sabe que os bons velocistas tendem a ter uma versão do gene chamada alfa-actinina-3, ou ACTN3, enquanto corredores de longas distâncias tendem a apresentar uma versão diferente, a AC'TN2, e os corredores mais rápidos tinham não apenas uma, mas duas cópias do ACTN3.

A investigação na terapia gênica, com objetivos voltados ao tratamento e prevenção de doenças, está avançando continuamente. $O$ conhecimento científico sempre pode ser utilizado sem ética e ilegalmente. Assim, esta tecnologia pode 
rapidamente infiltrar-se nas atividades esportivas, contaminando os atletas. Como os genes funcionarão no doping? Imagine os genes como o software de nosso organismo. Como num computador, os genes contêm códigos que assinalam, para cada célula em nosso organismo, quais são e quando devem realizar certas tarefas. Se tivermos uma falha no código que leve nosso computador a não funcionar apropriadamente, um técnico de computador pode inserir um segmento do código correto para corrigir o defeito. A transferência de genes é similar a fazer mudanças no softzuare de nosso computador pessoal. Quando isto é realizado com material genético num organismo vivo, isto é conhecido como terapia genética. Se o computador esta funcionando bem, mas nós (uieremos fazcr um upgrade em certa área, podemos arrumar um software que reforce os códigos existentes, tornando-o mais poderoso ou com mais recursos computacionais. O upgrade genético para aumentar a força muscular numa pessoa normal, utilizando-se a transferência de genes, é a base da terapia gênica, e no caso de atletas, do doping genético.

A injeção de camundongos com o gene de crescimento conhecido como fator I de crescimento (IGF-I) levou estes animais a obterem uma musculatura $30 \%$ mais forte. Assim, é possivel que a transferência de genes dirigida ao músculo seja usada para aumentar seu rendimento. $O$ doping gênico foi um problema para as olimpíadas de agosto de 2004 em Atenas, mas em 2008, poderá ser problema nos jogos olímpicos de Beijin.

Recentemente, os cientistas identificaram o gene responsável pela sintese de eritropoetina (EPO), o qual estimula a eritropoese (formação de hemácias, células vermelhas sangüíneas). Estas células são importantes para provas de resistência como a maratona e o ciclismo. A eritropoetina sintética, utilizada para tratamento de anemia é considerada ilegal pelo Comitê Olímpico Internacional, foi o centro de um escândalo de doping na clássica competição de ciclismo na França, em 1998. Utilizando como veículo vírus não patogênicos, o gene EPO já foi inoculado em músculos da perna de primatas, para mantêlos com alto suprimento de hemácias. A dificuldade neste trabalho, como em outros casos de terapia gênica, é controlar a atividade do gene EPO ligado ao vírus. Este é um problema tão importante na terapia gênica que logo terá uma solução tecnológica.

Devido ao fato de a transferência de gene usar o próprio organismo do atleta para desenvolver mudanças a nível celular, as evidências químicas do doping genético não são tão aparentes, como nos casos do uso de drogas, como esteróides e anfetaminas. As tecnologias disponiveis incluem a biopsia muscular, 
imagens obtidas por ressonância magnética e a utilização de alguns marcadores do vírus vetor, que transporta o gene alterado no organismo. Ao longo dos anos, observou-se que alguns técnicos e empresários, para aumentar a performance dos atletas, querem usar o conhecimento científico mais moderno. Por isto, logo devem ser regulados os efeitos da engenharia genética no esporte e iniciado o desenvolvimento de métodos para deteç̧ão do doping molecular. 


\section{5 \\ Agricultura e Genes}

Atualmente estamos entrando em uma nova era da agricultura com um papel central da biologia molecular, devido ao enorme avanço nos conhecimentos básicos da biologia vegetal e a aplicação de técnicas de engenharia genética. Esta revoluçāo vai depender menos das inovaçōes mecânicas ou químicas e mais do uso intensivo do saber científico e técnicas moleculares e celulares. As promessas da biotecnologia agrícola focalizam a produtividade, a redução de custos, a geraçāo de inovações e melhorias nos alimentos e o estabelecimento de práticas agrícolas mais ecológicas. Nunca houve tanta aplicação prática da ciência como na área agrícola.

\section{Biodiversidade e Riqueza}

A maior parte de aproximadamente 30 milhões de espécies de plantas, animais, bactérias, fungos e virus que existem no nosso planeta encontra-se nas florestas tropicais. Na floresta Amazônica, por exemplo, 15.000 espécies de animais foram catalogadas, oito mil das quais consideradas novas quando descobertas. Quarenta por cento dos peixes de água doce, $25 \%$ das espécies de pássaros e 5.000 espécies de árvores conhecidas no planeta são encontradas na Amazônia.

O número de microorganismos encontrados no solo é enorme. Utilizando-se marcadores de DNA, estima-se que em um grama de solo da floresta nativa sejam encontradas mais de duas mil espécies de microorganismos. Imaginem os milhares de novos genomas e proteomas que serão descobertos nesta diversidade biológica! Estimem o número de genes inéditos que serão conhecidos em nossa biodiversidade! Entretanto, o desflorestamento diminui enormemente o número e as espécies de bactérias c fungos, além de alterar várias propriedades do solo, como o $\mathrm{pH}$, elementos químicos, densidade e porosidade. 
Desde que as técnicas de biologia molecular tornaram-se disponiveis, avalanches de descobertas estão sendo divulgadas relacionando a biodiversidade com saúde, principalmente na área dos fármacos. Este desenvolvimento científico levará a mais do que uma revolução na área médica, pois se refletirá na economia, na política e na qualidade de vida do ser humano. Novos medicamentos desenvolvidos com base na biodiversidade serão utilizados para tratamento de doenças intratáveis ou tidas como de difícil terapia. Novas formas de aplicaçāo de drogas estão sendo inovadas. Em breve, ao usar sabonetes, pastas de dente, cosméticos, aerossóis e alimentos, uma pessoa poderá estar tomando sua dose diária de medicamentos. Nos últimos 10 anos, 60\% das drogas novas usadas no tratamento de câncer foram descobertas nas florestas tropicais. $\mathrm{O}$ mercado mundial de medicamentos derivados de plantas é de 200 bilhões de dólares/ano.

Apesar dos esforços realizados pelas universidades e institutos de pesquisa nacionais, a diversidade biológica brasileira ainda é pouco investigada. Verdadeiras barreiras restritivas à pesquisa e inovação nesta área são as leis rígidas e verticalizadas vigentes na burocracia pública. É importante concentrar o debate no que é factivel e não em fantasias. Os avanços do conhecimento impõem a necessidade urgente de mudanças destas normas. É importante traçar leis flexíveis para determinar, deliberar e facilitar a investigaçāo com material biológico, bem como a cooperação nacional e internacional.

Já é hora de encarar os receios e as vantagens do estudo da biodiversidade. Inexplorada e desconhecida, ela tem valor zero para a sociedade, pois não gera empregos nem riquezas. Não resta dúvida de que é necessário prevenir possíveis abusos. No entanto, dificultar e burocratizar a investigaçāo científica tira o ânimo e a competitividade de nosso país e não resolve o problema. Afinal, quantas espécies de microorganismos podem estar saindo no barro ou na poeira aderida nos tênis de nossos turistas?

\section{Biotecnologia Agricola}

Não resta dúvida que o mundo está crescendo. A população hoje é de aproximadamente seis bilhões de pessoas. As estimativas demonstram que ela será nove bilhōes em 2050. Isso significa uma população crescendo na base de 78 milhōes por ano e que cerca de $20 \%$ deste crescimento demográfico estará na Índia, 50 milhões de pessoas aumentará na Ásia, 18 milhões na África e 8 milhões na América Latina e no Caribe. O restante deste crescimento estará em países estáveis, como os Estados Unidos e Europa. Mais do que isto, 
enquanto a economia dos países ocidentais crescerá aproximadamente $2 \%$, a China vai crescer mais do que $8 \%$ e a Índia em torno de $5 \%$. Isto significa que a população destes países terá mais dinheiro para o consumo. Por outro lado, os países em desenvolvimento estão se urbanizando, o que induzirá a diminuiçāo dos produtores e o aumento dos consumidores. Para onde isto poderá direcionar o mundo?

O passo lógico será um aumento da produção agrícola. A biotecnologia pode oferecer aos agricultores uma maneira mais elaborada de produzir cultivares. Os principais benefícios da biotecnologia agrícola incluem resistência a doenças e pragas, reduçāo do uso de pesticidas, frutas e grãos com composição mais nutritiva, tolerância a herbicidas, mais rápido desenvolvimento dos vegetais e melhoria do sabor e qualidade do alimento. As plantas são manipuladas geneticamente (GM) de maneira mais fácil do que animais. Assim, o avanço nesta tecnologia aplicada a plantas será mais rápido do que para animais. $O$ solo para cultivo está limitado devido aos ambientalistas. A biotecnologia poderá melhorar a eficiência da seleção natural de plantas e aumentar a produtividade agrícola. Nos próximos cinco anos os alimentos transgênicos comerciais terão seus genomas conhecidos. Estes produtos utilizarão menos fertilizantes, crescerāo em terrenos ácidos e áridos e produzirāo mais do que uma planta comum.

O suplemento de alimento deve crescer no mundo. Para continuar este aumento utilizando-se da agricultura tradicional, teríamos necessidade de plantar em mais 10 milhões de hectares. Isto seria uma catástrofe para o ecossistema. Ou seja, isto significaria mais desmatamento com drásticas conseqüências para - meio ambiente. O suprimento de alimento deve dobrar nos próximos 30 anos. No entanto, $80 \%$ da futura produçāo de alimentos deve continuar sendo em terras utilizadas hoje, ou seja, haverá limitação para expansão de solos produtivos. Um dos maiores problemas será na África que terá um solo com diminuição da fertilidade, difícil aplicação da melhoria tecnológica, isolamento rural devido à falta de estradas e transportes, bem como educação deficiente e falta de serviço de saúde.

Em 2003, as plantaçōes GMs foram cultivadas em mais de 70 milhões de hectares de 18 países, o que representa uma área duas vezes maior que a Inglaterra. Aproximadamente cinco milhōes de pequenos agricultores no Brasil, China, Índia, África do Sul e México estão plantando algodão GM resistente a pragas. Calcula-se uma economia de cerca de US $\$ 500$ por hectare, principalmente através uma redução de $70 \%$ no uso de pesticidas. O cultivo de plantas GMs está crescendo no mundo todo e já é bastante difundido nos EUA, Canadá e 
Argentina, mas somente agora está sendo liberado em alguns países da Europa, pois ainda existe receio quanto à ameaça que ele representa para o meio ambiente e a saúde humana e animal.

As maiores contribuiçōes dos vegetais GMs ainda estão para chegar. Uma delas, provavelmente, será a reduçāo drástica do uso de agrotóxicos. Este é o caso das variedades de feijão e mamão resistentes a doenças viróticas, ou da melhora do milho e do algodão resistentes a lagartas. No Brasil, a Empresa Brasileira de Pesquisa Agropecuária (Embrapa) investiu muito nesta tecnologia e desenvolveu inúmeros tipos de plantas modificadas. China, Cuba e Índia avançam velozmente nas plantas transgênicas. A investigação de plantas geneticamente alteradas trará benefícios para a saúde pública. Algumas vantagens já foram obtidas somente pela redução do uso de inseticidas.

Maiores benefícios virão com o desenvolvimento de vacinas, anticorpos e outras proteínas medicamentosas. Vacinas contra hepatite $B$, bactérias e vírus que causam diarréias foram desenvolvidas em batatas e bananas e estão sendo testadas. Possivelmente para fins comerciais estas vacinas serāo produzidas em bananas, alface ou em suco de tomate, para serem ingeridas. Uma das vantagens é que estes produtos não serão administrados por injeção e estarão livres de possíveis contaminaçōes por agentes patogênicos humanos. Estas vantagens devem ser mais discutidas pela mídia e ignorá-las não é uma opção.

Os principais produtos melhorados pelo uso da biotecnologia foram o milho, a soja e as batatas que necessitam de menor aplicação de pesticidas/herbicidas; a soja com menor teor de lipídeo saturado, mais ácido oléico e maior estabilidade à oxidação; o mamão papaya resistente a vírus; o arroz que cresce mais rápido, mais rico em proteínas e capaz de tolerar melhor o solo ácido; a batata e o milho resistentes a doenças e com produção aumentada; entre outros. A produçāo de novas variedades de cultivares pela biotecnologia continua.

Veja um belo exemplo do que pode ser a agricultura nos próximos anos. O ser humano e o trigo caminham juntos pelo planeta pelo menos há 10.000 anos, adaptando-se a climas e solos diferentes. $O$ homem tornou-se dependente do trigo, que é cultivado em mais de 70 países. Utilizando-se deste cereal foram descritos recentemente genes que dão habilidade ao trigo de crescer em diferentes climas, permitindo a esta planta sobreviver em condiçōes extremas. Os dois genes revelados foram o VRN, que ativa a florescência, e o VRN2, que atrasa este processo, permitindo ao trigo desenvolver-se desde regiōes de longo inverno até áreas temperadas e tropicais. 
Os benefícios esperados num futuro próximo são as reduçōes dos níveis de toxinas naturais em plantas, a obtenção de métodos mais específicos, simples e rápidos para localização de um agente patogênico, toxinas e contaminantes e o aumento do tempo de exposição nas prateleiras dos supermercados sem os produtos estragarem. Os principais produtos já desenvolvidos para o mercado incluem o óleo de soja e de canola contendo mais estearato, podendo-se produzir margarinas mais saudáveis, melōes menores e sem sementes, bananas e abacaxis com menor tempo de maturaçāo, ervilhas de crescimento mais rápido e em maior quantidade, amendoim com mais proteínas e bananas resistentes a fungos. Ainda poderemos ter tomates com maior concentração de antioxidante (licopeno); batatas com maior conteúdo sólido (amido), o que reduz a quantidade de óleo absorvido durante a fritura; frutas e verduras com maiores teores de vitaminas, como a $\mathrm{C}$ e a $\mathrm{E}$; alho que produz mais alicina, possivelmente socorrendo na redução dos níveis de colesterol; arroz com maior teor de proteínas, utilizando genes obtidos de ervilhas; cerejas com maior nível de ácido elágico, um agente anticancerígeno natural, entre outros.

A população mundial deverá dobrar, ou seja, o planeta terá aproximadamente 10 bilhōes de pessoas até 2050 . Poucas outras tecnologias serāo capazes de oferecer as mesmas vantagens da biotecnologia, com o potencial de socorrer e evitar a fome no próximo século. Solos áridos e ácidos poderão ser utilizados para agricultura com a mesma eficiência de um solo fértil. Isto certamente aumentará a economia dos países em desenvolvimento, gerando mais empregos e maior produtividade.

Alguns acreditam que a ciência está planejando a natureza melhor do que a própria natureza. Entretanto, os impactos e as implicaçōes desta tecnologia ainda não são completamente compreendidos. A discussão do momento é sobre os riscos e benefícios possiveis dos organismos geneticamente modificados (OGMs), sob o ponto de vista de uma ciência ambientalista e ecológica. Ou seja, como os OGMs devem ser desenvolvidos e regulados levando em conta a perspectiva científica, política, socioeconômica, moral e ética.

Um monitoramento bem planejado é crucial para identificar os riscos de um OGM no ambiente, principalmente quando há razão de suspeita de um problema possível. Em alguns casos, quando uma planta GM é cultivada, este monitoramento detecta riscos ao ambiente que não eram evidentes em pequena escala. Ecologistas e ambientalistas do mundo todo, a princípio, fazem oposição radical aos OGMs, principalmente às plantas geneticamente manipuladas. 
É difícil entender esta posição. Oposição radical contra alimentos transgênicos é o triunfo do dogma sobre a razão. Ou da esquerda sobre a direita. Ora, os transgênicos servem tanto para o capitalismo quanto para o socialismo. É melhor nāo entrar neste véu ideológico.

Por que não fazem campanha contra os medicamentos e vacinas produzidas por modificação genética? A mesma tecnologia utilizada para inserir um gene humano na levedura a fim de produzir insulina para indivíduos diabéticos é usada para modificar uma plantação GM. Qual a razão de uma técnica poder ser usada para produção de medicamentos, mas não poder modificar vegetais tornando-os resistentes a pragas? Porque existe esta reaçāo gigantesca dos ativistas verdes contra a modificaçāo genética de plantas?

Devido à comercialização de plantas GM ser relativamente recente e limitada somente a poucos tipos de vegetais muitas das questões levantadas necessitam de um estudo mais profundo, pois somente foram analisadas empiricamente. Mas os riscos dos OGMs são mais conhecidos entre os ecologistas, as agências reguladoras e o público, enquanto os benefícios ao meio ambiente necessitam ainda serem pesquisados e documentados com mais rigor científico.

Por centenas de anos as plantas têm sido usadas para tratamentos e terapias de inúmeras doenças. Com o avanço da biotecnologia, as plantas estāo começando a serem utilizadas com 'fábricas' produtoras de proteínas terapêuticas que servirão de matéria-prima para formulação de medicamentos. Plantas produtoras de drogas são resultados de uma aplicação alternativa da biotecnologia. Esta metodologia é de baixo custo, segura e mais eficiente se comparada aos tradicionais processos utilizando fermentaçāo microbiana ou culturas de células animais. Uma outra vantagem é de que as plantas não propagam agentes patogênicos que podem infectar o ser humano ou outros animais.

Comparado com outros métodos existentes, a planta tem mais habilidade para assimilar a informação genética e produzir proteínas complexas que podem ser usadas na formulação de remédios mais efetivos. Os métodos de culturas de células são caros e trabalhosos e não produzem a quantidade suficiente de proteínas terapêuticas para atender as necessidades do mercado. Em muitos casos, o custo de produção de uma proteina medicamentosa é significativamente barato porque não necessita tanto de investimentos como nos métodos tradicionais de produção. 
A humanidade vem modificando plantas no nível genético desde o seu primórdio. O destino da sociedade humana, bem como da agricultura, tem sido mutuamente vinculado $\mathrm{e}$ dependente desde então. A agricultura permitiu ao ser humano deixar de ser somente caçador para construir seu desenvolvimento econômico e cultural. Nossos ancestrais escolheram umas poucas plantas selvagens e, gradualmente, as modificaram pela seleção das maiores, mais saborosas e mais resistentes, para então propagá-las. Assim, organismos têm sido alterados por milênios, nos trazendo arroz, trigo, milho, soja, batata e tomates que têm poucas semelhanças com seus ancestrais. Por exemplo, o tomate e a batata continham potentes toxinas. Hoje, variedades destas plantas têm sido cultivadas, produzindo alimentos saudáveis e nutritivos.

A maioria das plantaçōes não é natural por apresentar diferenças com seus ancestrais selvagens e, também, devido à sua origem e domesticação ter ocorrido em locais diferentes dos de sua origem. Por exemplo, o Brasil produz milho e soja que sāo variedades nativas do México e da China, respectivamente. O trigo foi domesticado na Mesopotâmia, o café tem origem na Etiópia, a laranja na Índia, a cana de açúcar em Papua Nova Guiné, a batata na Europa, a mandioca na África, a batata doce no Japāo. Um exemplo de modificaçāo genética foi revelado num estudo recente, onde os pesquisadores compararam genes de milho recuperados no México e nos Estados Unidos, e descobriram que três variantes genéticas foram sistematicamente melhoradas, provavelmente através de cultivos seletivos, por centenas e centenas de anos, pelos fazendeiros primitivos. A planta ancestral do milho, o teosinto, foi domesticada entre 6.000 e 9.000 anos atrás no México. Esta planta, considerada somente uma semente, ainda é encontrada no país. Pelo cultivo e seleçāo das características desejáveis, os agricultores daquele tempo causaram, no teosinto, mudanças fantásticas visando ao aumento da produção de alimento.

Há cerca de 5.500 anos o tamanho dos poucos grãos de milho na espiga era maior. Entretanto, todas as variantes genéticas já eram encontradas no milho 'moderno' que crescia no México há 4.400 anos. A planta foi tão modificada pelo cultivo direto que evoluiu para uma forma que não podia se desenvolver e dependia dos agricultores para sobreviver nas consecutivas gerações. Hoje, o México possui 59 espécies de milho. Os pesquisadores acreditam que dificilmente estas modificaçōes genéticas tenham sido realizadas de maneira 
espontânea. Aparentemente, os agricultores primitivos eram muito mais sofisticados do que imaginávamos. A diferença entre o teosinto e o milho está somente em alguns poucos genes que causam uma enorme mudança. Provavelmente $o$ agricultor primitivo descobriu que, plantando as sementes de um milho de melhor qualidade perto de um outro de pior qualidade, poderia ocasionar trocas benéficas no de pior qualidade nas próximas geraçōes. Caso tivesse encontrado a combinação correta, o fazendeiro ancestral dividia este conhecimento com seus amigos e parentes.

Somente três genes que apareceram num curto espaço de tempo melhoraram, dramaticamente, a qualidade do milho. Um gene mudou a arquitetura da semente. Outro induziu a produção de um grão mais macio, e uma mudança na consistência do milho, facilitando o brotamento da planta. $O$ terceiro gene tornou o grão de sabor mais agradável, pela modificação da concentração de amido. Provavelmente estas mudanças nas características do milho encorajaram os agricultores primitivos a propagarem a planta para outras regiōes.

A agricultura moderna somente se desenvolveu nos primeiros anos de 1700 , quando os cientistas criaram as primeiras plantas híbridas, obtidas pelo cruzamento de dois tipos de plantas diferentes. Na década de 1840, um monge austríaco, Gregório Mendel, trabalhando com ervilhas, definiu as primeiras leis da hereditariedade. Pesquisadores europeus, no início de 1900 , utilizando a técnica desenvolvida por Mendel, começaram a melhorar as plantas existentes. Em 1953, Watson e Crick descobriram a estrutura do DNA. Vinte anos após, foi descoberto como isolar genes. Na década de 1980, a informação genética pôde ser transferida de um organismo para outro. Pela manipulação de genes, os pesquisadores puderam formar novas proteínas que protegem a planta contra doenças. Em 1985, plantas geneticamente modificadas foram testadas no campo. O tomate Flavr Savr, que tem seu processo de maturação retardado, foi liberado para consumo nos EUA em 1994. Logo após, foi desenvolvida a soja resistente a herbicidas. De lá para cá, inúmeras plantas foram alteradas geneticamente.

Como vimos os avanços na genética foram progressivamente rápidos. As aplicações deste conhecimento em processos inovadores estão apenas se iniciando. Os genes transferidos artificialmente para o genoma de um organismo, isto é, os transgenes, permitem a criação de organismos que não podem ser obtidos através de uma reprodução sexual normal. O ser humano tem receio do alimento que come. Mas a civilização foi desenvolvida utilizando plantas geneticamente modificadas pela natureza e pelo homem. A humanidade nāo 
existiria se não fosse esta técnica empiricamente desenvolvida pelo agricultor primitivo há mais de 8.000 anos. Assim, na evolução da espécie, o ser humano se alimentou de plantas geneticamente modificadas pela natureza. Por milhares de anos o arroz, na China, e o milho, no México, por exemplo, foram alterados através do cultivo seletivo. Com efeito, foi praticamente uma revolução verde na pré-história.

Desde então a demanda global por alimento tem levado ao melhoramento dos vegetais. A biotecnologia tem desenvolvido tecnologia para produzir alimentos mais saborosos e nutritivos, com alta produtividade das plantas que são protegidas naturalmente das doenças e pragas. As plantações biotecnológicas estão se tornando significantes componentes da economia de vários países, inclusive do Brasil. A biotecnologia vegetal tem feito o possível para o melhoramento seletivo e hibridização das colheitas. Este processo permite a transferência de somente um ou poucos genes desejáveis, permitindo o desenvolvimento de vegetais benéficos sem problemas indesejáveis. A tecnologia de hoje permite a alteração de uma característica da planta, reduzindo o tempo do desenvolvimento de uma planta melhor. Ao invés de gastar 10 a 12 anos para desenvolver plantas da maneira tradicional, misturando milhares de genes, no sistema moderno seleciona-se um gene específico de qualquer vegetal que é posteriormente colocado no genoma de uma outra planta através da biotecnologia.

Além de ser benéfico em termos de crescimento, proteçāo contra pragas, produtividade e, conseqüentemente, economia, esse método também pode ser saudável para o meio ambiente devido ao fato de as plantações protegidas contra pragas, por exemplo, reduzirem a utilização de pesticidas. A transgênese de plantas também reduz a necessidade de controle de pragas, o tempo e a área cultivada, protegendo o solo. Por séculos, os agricultores têm usado a biologia pela sua vantagem de modificar genes para produzir melhores pães, cervejas, vinhos e queijos. Os processos por eles empregados foram semelhantes aos utilizados pela biotecnologia agrícola atual.

Um belo exemplo está no processo usado para produzir queijos. Num passado ainda recente, a principal enzima envolvida era a renina, extraída do estômago de bovinos. Utilizando a biotecnologia remove-se o gene específico que codifica a renina e se produzem bactérias através do processo de fermentação, eliminando a necessidade da extração do bovino. Atualmente, $50 \%$ da renina usada na fabricação de queijos é produzida por fermentação. O fermento utilizado na fabricação de pães também foi trabalhado pela biotecnologia, resultando numa 
levedura que age mais rapidamente no processo de produzir pães e outras massas. Este fermento tem certos genes rearranjados e duplicados. Os padeiros ancestrais poderiam ter feito a mesma coisa, mas só alcançariam resultados com dezenas de anos de experimentos. 


\section{Considerações Finais: \\ genes e responsabilidade}

As implicações e os problemas éticos, legais, morais c sociais que resultam dos novos conhecimentos científicos e das tecnologias não poderão ser esquecidos. É importante que cada setor da sociedade zele pela boa utilizaçāo do conhecimento cientifico e suas aplicações. Insistimos: a responsabilidade do uso de uma tecnologia é de cada um de nós.

Reflexões sobre a clonagem humana

Nos últimos 50 anos temos observado que a biotecnologia está fornecendo novas maneiras de solucionar problemas associados à reprodução humana, especialmente com a vida iniciada fora do organismo materno. Apesar dos avanços terem um grande significado para a sociedade, a interseção da reprodução assistida com técnicas de varredura genética e seleção de sexo, por exemplo, confronta os pacientes com as vantagens e os dilemas das novas oportunidades.

A genética e a revoluçāo genômica e proteômica desenvolveram informaçōes e técnicas que podem ser utilizadas para mudar o conceito sobre o que significa o ser humano. A ciência moderna fornece credenciais biotecnológicas e promessas às nossas assombrações infantis, refletidas em sonhos místicos sobre os ancestrais, à inteligência sobrenatural, ao temor das coisas desconhecidas, às doenças genéticas do metabolismo, ao planejamento de um indivíduo melhor, à fonte da juventude e do prazer eterno, e agora, à clonagem humana.

A história da genética humana depende de um diálogo informado sobre a implicação ética, moral e social que resulta da multiplicidade de áreas envolvidas no desenvolvimento da pesquisa genética. Por exemplo, as questões bioéticas são pontos importantes da cultura pós-moderna global. Argumentos sobre pesquisa em células-tronco, a incerteza sobre a engenharia genética para melhorar a vida do ser humano e dúvidas sobre o acesso da população aos 
avanços genéticos contemporâneos sāo pontos que a sociedade necessita resolver nos próximos anos, enfrentando as novas possibilidades das utilizaçōes e promessas que estão vindo numa velocidade espantosa, a respeito das implicaçōes das descobertas de genômica e proteômica bem como do uso das células-tronco.

Por exemplo, o conceito do status moral de um embrião humano deve ser discutido e avaliado pela sociedade. Um embriāo é um ser humano, um ser que se desenvolverá por toda a vida, se provido de nutrientes e ambientes adequados. É necessário regulamentar o uso destas tecnologias para finalidades respeitáveis, aceitando a modernidade das técnicas reprodutivas, sem comprometer a liberdade humana, a medicina, a moral social, a religiāo, a dignidade e a ética.

Além disso, assuntos relacionados com a reprodução humana levantam questões profundas de caráter íntimo e familiar, produzindo uma forte reaçāo emotiva popular contra o aborto e as pesquisas que utilizam embriões, célulastronco e clonagem humana. Estamos numa encruzilhada entre proteger a investigação biológica e biomédica e o progresso da medicina e da saúde pública, ou não regulamentar e legalizar estas atividades. A população, para participar e decidir, necessita ter, com transparência, mais detalhes para compreender o assunto.

A ciência como moralidade neutra é simplificação de nossa realidade. Devido aos valores enraizados na nossa cultura, a ciência não é neutra nas definições de prioridades, nas hipóteses propostas e nos questionamentos e dúvidas. Ciência e ética tiveram sempre uma relação difícil, baseada na ambição cientifica e no respeito à dignidade do ser humano. A bioética não é somente a ética baseada na biologia, mas é a ética a serviço do ser vivo. A vida não é meramente fisiológica ou bioquímica, mas também mental, social, cultural, política e espiritual. A atividade científica deve ser humanizada dentro dos padrōes de uma profunda reflexão sociológica e ética.

É a partir desse olhar que deve ocorrer o debate sobre a clonagem humana terapêutica versus clonagem reprodutiva. A clonagem terapêutica não deve ser confundida com a reprodutiva. A clonagem terapêutica é uma nova tecnologia com potencial de aliviar ou curar doenças lesivas em milhares de pessoas. Entretanto, esta investigação tem sido questionada devido, em parte, ao fato de esta tecnologia também ser usada para clonagem reprodutiva.

Qual a diferença básica entre os dos tipos de clonagens? Na clonagem reprodutiva a intenção é produzir um outro ser humano. Pelo contrário, a clonagem terapêutica utiliza células humanas especificas, genes e outros tecidos, somente para propósito médico. É importante distinguir entre criar um ser 
humano e a clonagem terapêutica, que, usada em conjunto com a investigação de células-tronco, tem o potencial para produzir novos diagnósticos, medicamentos e vacinas.

A questão que cstá na raiz do problema é se um blastócito humano no quinto dia após o espermatozóide penetrar no óvulo é a mesma coisa que um blastócito clonado. $O$ transplante nuclear é o processo de retirar o núcleo de uma célula somática (não de um espermatozóide ou óvulo) e inoculá-lo em um óvulo cujo núcleo foi também removido. O ovo, contendo o núcleo transferido, divide-se a té chegar ao estágio de blastócito, do qual as células da massa celular interna sāo removidas e cultivadas. As células-tronco resultantes têm risco reduzido de rejeiçāo, desde que produzidas a partir de células do próprio paciente, para que as células sejam compativeis com os tecidos receptores. $\mathrm{Na}$ clonagem reprodutiva, as células resultantes do transplante nuclear são transferidas para o útero, que fornece os fatores críticos para prosseguir o desenvolvimento até formar o embriāo.

Na clonagem terapêutica, as células se desenvolvem numa placa de cultura, na presença de nutrientes especiais, por poucos dias, até chegar-se a um conjunto de aproximadamente 120 células que podem ser usadas para formar célulastronco. Assim, as células não são nunca transferidas para um útero, nāo podem se desenvolver num ser humano (ou animal). Adicionalmente, não há fertilização neste processo. O problema é que há uma diferença entre criar uma vida em laboratório e a possibilidade de, através da clonagem terapêutica, livrar o mundo de inúmeras doenças e lesões graves. A lógica diz que é errado produzir uma nova vida, mas melhorar a vida de outros não justifica a experimentação na clonagem terapêutica?

De um lado, um grupo imagina que um mundo novo está se abrindo para a cura de doenças. Do outro, há os que acreditam que a vida começa na concepção. Uma experiência com células-tronco que levasse à destruição de um embriāo seria um assassinato? No momento, esta pergunta é básica, pois cientistas estão tentando clonar um embrião humano até o estágio de blastócito. Entretanto, ao invés de implantá-lo no útero para desenvolver um bebê, eles destruirão o embrião para produção de células-tronco. Não há dúvida de que este resultado seria a primeira evidência séria da possibilidade de domínio da técnica da clonagem humana.

A existência de linhagens de células-tronco cria possibilidades extraordinárias de tratamento de doenças, substituindo tecidos cancerosos ou lesados, ou de investigações das a nomalias genéticas. Porém, cenários catastróficos podem ser 
divulgados, como sua utilizaçāo para clonagem reprodutiva, ou para fabricar ou produzir em massa embriōes, ou mesmo para destruição em massa. Nāo é ainda possivel, tecnicamente, separar o 'bom' do 'mau' uso da tecnologia da clonagem, do mesmo modo que é impossivel separar a 'má' da 'boa' genética, que pode desenvolver terapias nunca imaginadas para algumas doenças ou armas de bioterrorismo.

Em resumo, há dois tipos fundamentais de clonagem humana por transferência nuclear: a reprodutiva e a terapêtica. $O$ objetivo do primeiro tipo é produzir uma criança geneticamente idêntica a um indivíduo. A clonagem terapêutica tem a finalidade de produzir células embrionárias (células-tronco) geneticamente idênticas às do paciente. Estas células podem se diferenciar em diferentes células para tratamento de uma variedade de doenças degenerativas que o doador do DNA pode sofrer.

O debate científico sobre a clonagem humana tem como pontos centrais o direito de um indivíduo ou um casal estéril ter filhos e o da criança clonada não ser exposta a um risco excessivo de desenvolvimento de anormalidades. A definiçāo de risco aceitável é totalmente subjetiva. Se o risco do desenvolvimento de uma anormalidade ou de morte pré-natal na clonagem humana, por exemplo, for menor do que $3 \%$ - que é o risco observado na reprodução sexual normal -, um significativo número de pessoas opositoras da clonagem mudaria de opinião.

A tecnologia da clonagem ainda não está totalmente dominada. Em animais, um grande número de fetos é sacrificado no processo de produzir um clone saudável. Além disto, inúmeros defeitos genéticos aparecem na clonagem, prejudicando a saúde do clone. Estes seres geralmentc sofrem de obcsidade, envelhecimento prematuro, artrite e outros problemas médicos. Ao analisar 10.000 genes de animais clonados, verificou-se que uma grande quantidade de mutações genéticas era introduzida pela clonagem.

A parentemente, todos os riscos da clonagem reprodutiva humana têm como base os resultados observados nas clonagens de outros animais. A clonagem ainda é considerada uma técnica ineficiente e que produz animais com sérios problemas, como doenças respiratórias e desenvolvimento anormal da placenta. Um dos pontos considerados na produção de células-tronco é a utilização dos embriōes congelados in vitro nas clínicas de reproduçāo. Estes embriōes poderāo ser simplesmente destruídos e transformados em células-tronco, ou ser implantados no útero de uma mulher. A destruição do embrião clonado para produção das células-tronco levanta os mesmos problemas éticos da destruição dos embriōes congelados nas clínicas de reprodução. O desenvolvimento de 
um feto obtido por clonagem é o ponto ético importante na clonagem humana. Nāo é ético tentar a clonagem reprodutiva quando não se tem a evidência necessária que não levaria risco para o bebê e a mãe.

Uma sugestão científica prudente seria a investigação extensiva da clonagem por transferência nuclear em primatas antes de uma decisāo final a favor ou contra esta tecnologia reprodutiva. Assim, a tecnologia da clonagem se focalizaria na redução de fetos inviáveis e no número de mutaçōes introduzidas. Após a resolução dos problemas técnicos da clonagem animal, a clonagem humana poderá ser uma possibilidade. Entretanto, o mercado para esta clonagem deverá ser muito pequeno e secundário. Assim como no caso dos bebês de proveta, que causaram um intenso debate ético quando foram introduzidos, mas agora são aceitos, a sociedade deverá aceitar que uma pequena percentagem da raça humana será de clones.

A explicação que se deve dar à clonagem terapêutica tem como pontos importantes o benefício terapêutico e o custo ético da destruição de um embrião clonado. Muitos consideram que o embriāo em sua primeira fase de crescimento tem o status de um indivíduo com todos os direitos humanos fundamentais $\mathrm{e}$ consideram a destruiçāo deste embriāo equivalente a um assassinato. Nos primeiros estágios de desenvolvimento de um embriāo, porém, o que se tem é um conjunto de células sem o mais rudimentar sistema nervoso. A divisão deste conjunto de células resulta em dois ou mais gêmeos monozigóticos. Assim, se este embrião pode ser considerado um individuo, é bastante questionável. Por outro lado, é enorme o percentual de resultados negativos na reprodução sexual natural, motivados pelo não implante do embrião no endométrio uterino, ou seja, por abortos espontâneos.

Para evitar controvérsias morais e éticas, alguns pesquisadores estāo envolvidos na produção de células-tronco a partir de um óvulo não fertilizado de macaco, ou seja, por partenogênese. Acredita-se que, utilizando este método como fonte de material para células-tronco, haja menos controvérsia ética ou moral, pois estas células serão criadas sem a união de espermatozóide e óvulo. Inúmeras questōes éticas necessitam ser revistas e repensadas para chegarmos a um posicionamento tranqüilo da sociedade. Isto iria acontecer mais cedo ou mais tarde. Ameaças aos seres humanos como meios e não fins não são mais possiveis. Os embriōes clonados devem ser tratados com respeito e não somente como uma linhagem celular.

Uma sugestão científica prudente seria a investigação extensiva da clonagem por transferência nuclear em primatas antes de uma decisão final a favor ou 
contra esta tecnologia reprodutiva. Assim, a tecnologia da clonagem se focalizaria na redução de fetos inviáveis e no número de mutações introduzidas. Após a resolução dos problemas técnicos da clonagem animal, a clonagem humana poderá ser uma possibilidade. Entretanto, o mercado para esta clonagem deverá ser muito pequeno e secundário. Assim como no caso dos bebês de proveta, que causaram um intenso debate ético quando foram introduzidos, mas agora são aceitos, a sociedade deverá aceitar que uma pequena percentagem da raça humana será de clones. O simples posicionamento contra todas as tecnologias criadas para clonagem celular levanta questões e dilemas éticos: qual é o direito do Estado proibir os cientistas de desenvolverem métodos para tratamento de doenças? Ou: a destruição de um punhado de células (blastócitos) que não tem ainda a menor evidência de um sistema nervoso, para salvar dezenas de pessoas, é aética?

O uso da clonagem humana, de células-tronco embrionárias e da intervenção genética não pode constranger a liberdade da ciência nem os valores contidos na sociedade. É preferível vetar o uso da clonagem humana somente para propósitos reprodutivos, ou seja, gerar uma criança clone. Tal atitude teria a vantagem de diminuir os argumentos contrários à clonagem. $\mathrm{Na}$ prática, este seria um esforço árduo, pois uma vez que exista um embrião clonado, torna-se difícil evitar que alguns cientistas secretamente o implantem numa mulher. Quando nos referimos à clonagem humana não há uma maneira fácil de decidir entre o que é útil e o que é inútil para a sociedade.

Certamente é melhor para o nosso país criar leis severas, mas que permitam dominar esta tecnologia de ponta, de maneira a desenvolver uma ciência moderna e responsável, com padrões éticos aceitáveis, do que deixar a decisāo para outra instância, outro país ou outra cultura. Temos de enfrentar esta realidade com coragem. Esta é a diferença entre ter uma ciência pioneira e inovadora ou ter um papel secundário no mundo da investigação científica. Afinal, qual é o valor maior, o da vida de uma pessoa adulta, ou de uma criança, sofrendo ou morrendo de uma doença degenerativa qualquer, ou o de um embrião de cinco dias que é um pouco mais do que uma massa de células? É este o futuro da medicina que queremos? É esta a ciência que vamos desenvolver? No meio acadêmico a discussão está avançando. No entanto, o debate está polarizado na sociedade, e é ela, conhecendo o problema e participando, que deve aprovar normas éticas razoáveis para o avanço deste conhecimento tornando-o útil para a saúde pública brasileira. 


\section{Bibliografia}

FOX-KELLER, E. O Século do Gene. Belo Horizonte: Crisálida/Sociedade Brasileira de Genética, 2002.

GARCIA, E. S. Um Olhar Sobre a Ciência. Rio de Janeiro: Editora Interciência, 2003.

HOWE, L. \& WAIN, A. Predicting the Future. Cambridge/New York: Cambridge University, 1993.

HUMAN GENOME SPECIAL ISSUE. Science, 291: 1145-1434, feb., 2001.

JONES, S. Deus, Genes e o Destino - na massa do sangue. Lisboa: Publicaçōes Europa-América LTDA, 1999.

LEWONTIN, R. A Tripla Hélice: gene, organismo e ambiente. Sāo Paulo: $\mathrm{Cia}_{\mathrm{a}}$ das Letras, 2002.

KAKU, M. Visions - how science will revolutionize the twenty-first century. New York: Oxford University Press, 1998.

NATURES'S HUMAN GENOME COLLECTION. Nature, may 2005.

RIDLEY, M. Genome - the autobiography of a species in 23 chapters. New York: HarperCollins Publishers, 1999.

WATSON, J. D. \& BERRY, A. DNA: the secret of life. New York: Knopf Publisher Edition, 2003. 
Formato: $16 \times 23 \mathrm{~cm}$

Tipologia: Bradley Hand ITC

ACaslon Regular

Papel: Print Max 90g/m² (miolo)

Cartāo Supremo $250 \mathrm{~g} / \mathrm{m}^{2}$ (capa)

Fotolitos: Engenho \& Arte Gráfica Ltda. (capa e miolo)

Impressāo e acabamento: Imprinta Express Gráfica e Editora Ltda.

Rio de Janeiro, dezembro de 2006.

Não encontrando nossos títulos em livrarias, contactar a EDITORA FIOCRUZ:

Av. Brasil, 4036 - 1aandar - sala 112 - Manguinhos

21040-361 - Rio de Janeiro - RJ

Tel.: (21) 3882-9039 e 3882-9041

Telefax: (21) 3882-9007

http://www.fiocruz.br/cditora

e-mail: editora@fiocruz.br 